\title{
O Uso de Hipertexto para Apoio a Reuniões Formais
}

Gladys Pierri Bernardo dos Santos

\author{
Orientador
}

Prof. Dr. Paulo César Masiero

Dissertação apresentada ao Instituto de Ciências Matemáticas de São Carlos, da Universidade de São Paulo, como parte dos requisitos para obtenção do título de Mestre na Área de Ciências de Computação e Matemática Computacional.

São Carlos

1992 


\section{RESUMO}

O hipertexto, ou texto não linear, surge como uma possibilidade de estender a noção tradicional dos arquivos contendo textos com uma hierarquia linear para uma organização mais complexa. Nele a informação é mantida em blocos discretos que se interconectam através de ligações, formando uma rede. A criação automática de banco de documentos organizados como hipertexto é um problema que vem recebendo crescente atenção na literatura especializada.

Neste trabalho usa-se um sistema de hipertexto para apoiar reuniōes formais, caracterizadas por circular de convocaçāo e ata, com objetivo de deliberar sobre diversos assuntos de um escritório. Para isso, inicialmente apresenta-se um estudo sobre os sistemas de hipertexto e suas inúmeras aplicações, alguns sistemas de apoio a reuniões que já foram ou estão sendo implementados e, finalmente, como um sistema de hipertexto pode apoiar reuniōes de uma maneira geral. Em seguida, este trabalho analisa um domínio de aplicação - reuniões formais - e mostra como sistemas de hipertexto podem auxiliar no processo de criação automática e busca em atas de reuniões.

Propõe-se um método para especificação de sistemas de armazenamento e recuperaçã̃o de documentos textuais para auxiliar a conversão de documentos para o formato hipertexto, como é o caso de atas de reuniões, que contém um grande volume de informação organizado em fragmentos relacionados entre si. Tal método considera o aspecto dinâmico do crescimento da base de dados hipertexto e apresenta uma solução automatizada para resolver o problema das ligações entre os fragmentos de texto a serem inseridos e os já existentes na base de dados. Na implementação dessa aplicação utiliza-se o sistema de hipertexto Hyperties e um sistema de apoio para a autoria da base de dados desenvolvido especialmente para esse fim. 


\section{ABSTRACT}

Hypertext, or non-linear text, has emerged as a new concept, extending the conventional linear structured text to a more complex structure. In a hypertext, information is stored as discrete chuncks of text linked into a net structure. The automatic development of a text data base organized as a hypertext is a problem which has been receiving a growing amount of attention in the literature.

A bibliographical review is presented which describes several hypertext systems and their applications; some systems to support meetings are discussed; and, finally, it is investigated how hypertext systems can be used to support meetings. Next, an application domain - formal meetings - is analyzed in this dissertation, aiming at creating and searching automatically a minutes data base.

A method for specification of systems for storage and retrieval of textual documents is proposed. Its main objective is to support the storage of documents as a hypertext. This method also proposes a solution for the dynamical growing of the data base, when new fragments of text to be inserted have to be linked to other fragments already existing in the data base. A prototype system has been implemented using the Hyperties system integrated with a taylor-made subsystem to support authoring. 


\section{ÍNDICE}

\section{Introdução}

1.1 Automação de Escritório e Hipertexto ................................................................... 1

1.2 Objetivos do Trabalho..................................................................................................

1.3 Organização do Trabalho ...........................................................................................

2. Revisāo Bibliográfica

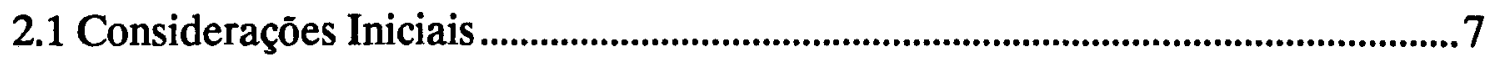

2.2 Sistemas de Hipertextos ..............................................................................................

2.3 Aplicações de Hipertexto............................................................................................15

2.4 Sistemas de Apoio a Reuniões......................................................................................25

2.5 Avaliação da Bibliografia ...........................................................................................32

2.6 Considerações Finais .........................................................................................................34

3. O Sistema Hyperties

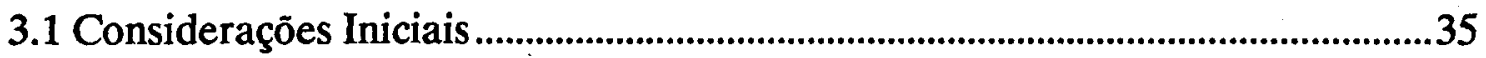

3.2 Características Gerais e Terminologia ......................................................................38

3.3 O Módulo de Autoria .....................................................................................................39

3.4 O Módulo de Navegação ..................................................................................................41

3.5 Considerações Finais ..............................................................................................43

4. Um Sistema de Hipertexto para Apoio à Reuniôes

4.1 Considerações Iniciais ..................................................................................................44

4.2 Descrição de Reuniōes de Congregação da Faculdade de Medicina de Ribeirão Preto ......................................................................................................................46 
4.3 Um Método para Especificação de Sistemas de Armazenamento e Recuperação de Documentos ..........................................................................................4

4.4 Especificação do Sistema de Apoio a Reuniões .......................................................50

4.5 Arquitetura Geral do Sistema..................................................................................65

4.6 Implementação de um Protótipo em Hyperties.........................................................66

4.7 Considerações Finais...............................................................................................68

5. Uso e Avaliação do Protótipo Implementado

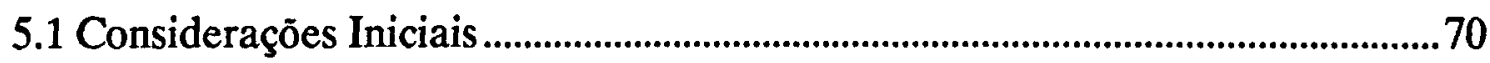

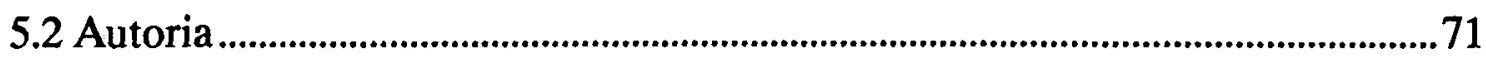

5.3 Navegação .................................................................................................................90

5.4 Sugestão de Recursos a serem Incorporados aos Sistemas de Hipertexto..........................................................................................................................96

5.5 Considerações Finais ....................................................................................................99

\section{Conclusões}

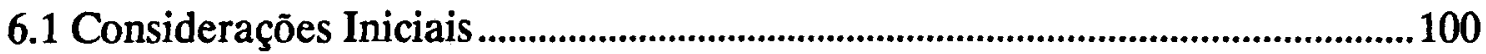

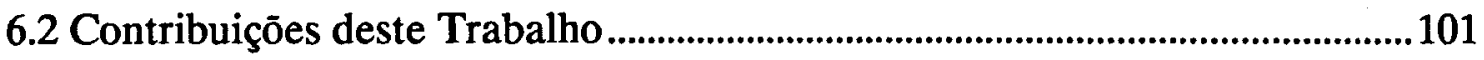

6.3 Sugestōes de Novas Pesquisas..............................................................................103

Bibliografia .........................................................................................................................

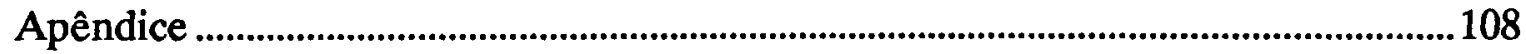




\section{Introdução}

\subsection{Automação de Escritório e Hipertexto}

O escritório é uma área onde o uso de computadores tem sido intenso. Várias ferramentas têm sido desenvolvidas para auxiliar, ou mesmo executar, tarefas rotineiras e solução de problemas como, por exemplo, processadores de textos que operam diretamente sobre a aparência final do documento; planilhas eletrônicas com facilidades suficientes para o usuário montar sua própria aplicação; correios eletrônicos, permitindo a comunicação entre as pessoas no escritório; sistemas gerenciadores de base de dados, que armazenam várias informações sobre o escritório, desde dados pessoais dos empregados até informaçōes gerenciais que apoiam as decisões dos gerentes; etc.

Entretanto, o principal apoio do computador tem sido dado ao trabalho individual. Para o trabalho em grupo, especificamente reuniōes de trabalho, de deliberações, e outras, existem poucos sistemas assistidos por computador e alguns 
ainda em fase de experimentação e em seus lugares vêem-se lousas, documentos em papéis e participantes fazendo anotações manuais. Estudos estatísticos indicam que os executivos empregam de 30 a $70 \%$ de seu tempo realizando reuniões. Portanto, é conveniente introduzir o computador também nessa atividade de escritório.

Muitas pesquisas dirigem o uso do computador e a tecnologia de comunicação para apoiar teleconferências ou conferências por computador, que basicamente enfatizam o uso do computador na comunicação assíncrona e nas redes. Outras pesquisas, mais recentes, dirigem o uso do computador para apoiar reuniōes de trabalho face-a-face, que são as mais comuns e são o objetivo central deste trabalho.

Os sistemas de computadores desenvolvidos para apoiar reuniões face-aface, que objetivam a soluçâo de problemas e propostas de novos projetos, caracterizam-se, como descrito por Stefik, em [St87], por estações de trabalho e microcomputadores interligados em redes e por programas que permitem a cada participante em seu equipamento lançar idéias sobre projetos e soluções de problemas, argumentar a favor e contra suas idéias e as de outros participantes, organizar essas idéias e revisar idéias e argumentos anteriores.

Neste trabalho, pretende-se estudar sistemas de computação para apoiar reuniões face-a-face formais, caracterizadas por circular de convocação e ata, com o objetivo de deliberar sobre diversos assuntos de um determinado escritório, isto é, reuniões que decidem, por exemplo, quem passará a chefiar determinado setor ou qual projeto deverá ser levado adiante ou não. Para isso, sem entrar no mérito de sistemas de apoio à decisão, têm-se os processadores de textos, onde se pode editar a circular de convocação e a ata da reunião; os gerenciadores de bases de dados tradicionais, onde se pode registrar as decisões tomadas; e, ainda, sistemas de arquivos, tornando possível a recuperação de informaçōes veiculadas em outras reuniōes, a revisão dos argumentos e a exibição de séries históricas de argumentos. 
A possibilidade de computadores poderem ser usados para apoiar a solução de problemas em grupo já foi imaginada há tempos atrás. Bush, em 1945, apresentou um sistema hipotético, Memex, que continha uma base de dados interativa pela qual rastros associativos de exploração podiam ser salvos para serem chamados de volta mais tarde e então percorridos. Bush acreditava que uma base de dados pública de informações de várias áreas da atividade humana integradas, melhoraria a qualidade da solução de problemas. Isso foi o início dos sistemas de hipertextos que se tem hoje, caracterizados por uma base de dados que é uma rede de nós textuais, janelas correspondendo aos nós da base, sistema de operação de janelas, ligações entre os nós e um sistema de navegação na base de dados.

Pelas características apresentadas, os sistemas de hipertexto podem vir a apoiar as reuniōes formais, substituindo o processador de texto tradicional por um sistema que, a partir da entrada da ata da reunião, permite que se faça, automaticamente ou não, as associações apropriadas com as atas anteriores e facilitando, através de mecanismos de acesso de navegação ou palavras-chaves, a recuperação de informaçōes.

\subsection{Objetivos do trabalho}

Um escritório cria um número muito grande de documentos e sāo necessários sistemas, apoiados ou não por computador, para controlar e auxiliar os encarregados de escritório a encontrar os documentos de que necessitam em seu trabalho. Em uma reunião, por exemplo, os participantes emitem opiniões, apresentam resultados e, principalmente, tomam decisões. Tudo é registrado em documentos que, frequentemente, são pesquisados posteriormente. Um sistema que 
apoie essa atividade é importante para torná-la mais efetiva, já que se emprega tanto tempo nela.

O objetivo deste trabalho $\varepsilon$ o desenvolvimento e implementação de um sistema de apoio a reuniōes face-a-face formais. Essas reuniões visam a deliberações de uma série de assuntos de uma organização e caracterizam-se por emissão de circular de convocação previamente à reunião e confecção de ata, isto é, relato por escrito das decisões tomadas durante a reunião.

O sistema deverá auxiliar na elaboração da ata e fazer as associações apropriadas com as atas anteriores, automaticamente, tornando possível a recuperação de informações sobre situações semelhantes à que esteja em discussão e quaisquer outras informações de interesse da organização.

Os sistemas de hipertexto oferecem facilidades para o desenvolvimento deste trabalho. Cada ata de reunião poderá ser identificada com um nó do hipertexto e ligado ao nó anterior que foi identificado com a ata da reunião anterior e assim sucessivamente. Os assuntos tratados na reunião e descritos na ata também poderão ser associados a assuntos semelhantes tratados em outras atas.

As atas de reuniōes costumam seguir padrões determinados pela organização ou mesmo por quem as elabora e se o texto contém uma estrutura explícita, então é possível importá-lo automaticamente para um sistema de hipertexto que o permita, criando as ligaçōes também automaticamente. A importação automática evita erros e esquecimentos que uma elaboração manual pode cometer, pois esses documentos podem ser muito complexos e extensos. Além disso, poder-se-ia aproveitar o programa de importação em outras organizações, com algumas adaptações.

E importante observar que a base de dados hipertexto constituída das informaçōes de atas será atualizada periodicamente, isto é, não se tem uma coleção de documentos para serem importados ou convertidos para um sistema de hipertexto de uma só vez, mas sim, tem-se documentos que periodicamente 
atualizarão a base de dados hipertexto, caracterizando, assim, o aspecto dinâmico da autoria da base.

Esse aspecto também motiva o desenvolvimento deste trabalho, já que se poderá avaliar os recursos que os sistemas de hipertextos oferecem ou que deveriam oferecer para apoio à atividade de autoria de hipertextos que crescem dinamicamente.

Para exemplificar esta nova aplicação dos sistemas de hipertexto considerarse-ão as reuniōes de Congregação que acontecem em algumas instituições da USP, especificamente as da Faculdade de Medicina de Ribeirão Preto. Esta aplicação, como poder-se-á observar em capítulos posteriores, diferencia-se das aplicações até então utilizadas que constituem-se de base de dados estáveis, no sentido de que não têm um crescimento regular.

\subsection{Organização do Trabalho}

Nas seções anteriores foram apresentadas as bases que motivaram a realização deste trabalho dentro do interesse atual de sistemas de hipertexto e automação de escritórios. Com o objetivo de dar subsídios ao desenvolvimento de um sistema de apoio a reuniões formais, que tenha como base um sistema de hipertexto, o capítulo dois descreve como são os sistemas de hipertexto genericamente e suas inúmeras aplicações, além de apresentar alguns sistemas de apoio a reuniões que já foram ou estão sendo implementados e, finalmente, mostra como um sistema de hipertexto pode apoiar reuniões de uma maneira geral.

As características gerais do sistema de hipertexto Hyperties a ser utilizado no desenvolvimento de um sistema de apoio a reuniões serão apresentadas no capítulo três. 
O capítulo quatro apresenta um sistema de apoio a reuniōes, considerando, como exemplo, as sessōes de Congregação que acontecem na Faculdade de Medicina de Ribeirão Preto - USP. Para isso, avalia os assuntos abordados por aquele colegiado, organizando-os de forma a permitir um melhor entendimento do procedimento relacionado a cada assunto para, então, definir quais os nós e as ligações a serem considerados. Como generalização desse problema, apresenta-se um método para especificação de sistemas de automação de escritório, dentro da sub-área dos sistemas para armazenamento e recuperação de documentos textuais.

Uma avaliação do sistema desenvolvido e dos novos recursos que os sistemas de hipertextos devem oferecer com relação à autoria e navegação é feita no capítulo cinco e, finalmente, no capítulo seis apresentam-se as conclusões a que se chegou com este trabalho, suas contribuições e as possíveis pesquisas que poderão ser desenvolvidas futuramente. 


\section{Revisão Bibliográfica}

\subsection{Considerações Iniciais}

Hipertexto é um poderoso conceito que já está mudando a maneira de como se pensa e usa a informação. Nele, a informação é mantida em blocos discretos que se interconectam através de ligações, formando uma rede. Isso significa que um leitor, lendo um documento em hipertexto, pode facilmente ter acesso a outras informações ou documentos, explorando-os de uma maneira individual e independente.

Neste capítulo se introduz o conceito de hipertexto, seus modos de recuperação de informação, a conversão automática ou não de documentos em papéis para hipertexto e suas aplicações. Também, são descritos alguns sistemas de apoio a reuniões, identificando-se as características fundamentais a esses sistemas e, finalmente, como aplicar hipertexto para apoiar reuniōes. 


\subsection{Sistemas de Hipertexto}

O hipertexto, ou texto não linear, surge como uma possibilidade de estender a noção tradicional dos arquivos contendo textos com uma hierarquia linear para uma organização mais complexa. Para muitos assuntos do dia-a-dia, o armazenamento linear de um texto não é suficiente. Hall e Papadopoulos, em [Ha90], citam o exemplo de uma pesquisa numa enciclopédia convencional. A informação pesquisada, quando encontrada, pode ter referências para pontos que devem ser pesquisados em outros trechos do volume ou até em outros volumes e assim por diante. A estrutura lógica de referências dentro do documento é complexa e a organização seqüencial não é adequada para representar tal estrutura. A tecnologia de hipertexto promete organizar tal base de informações cruzadas de uma maneira mais eficiente e efetiva.

Um sistema de hipertexto, de acordo com Hall e Papadopoulos, organiza a informação em blocos discretos ou nós. Cada nó representa uma pequena seção da enciclopédia e ligaçōes são feitas para juntar estas seçōes. O leitor de uma enciclopédia num sistema de hipertexto navega através das seções simplesmente referindo-se a um comando, teclas ou botōes de um mouse.

Conklin, em [Co87], conceitua o hipertexto como sendo janelas com fragmentos de textos ou gráficos numa tela de computador associadas a objetos numa base de dados, e ligações entre objetos representadas graficamente como rótulos e na base de dados como ponteiros (Fig 2.1). A ligação é a principal característica dos sistemas de hipertexto, pois é ela que possibilita a organização não linear do texto.

Conklin considera ainda as seguintes características para um sistema de hipertexto: uma base de dados formando uma rede de nós textuais ou gráficos; janelas na tela correspondendo aos nós da base; operações padrões de sistemas de 
janelas; símbolos de ligação nas janelas para quaisquer outros nós da rede, facilidades de criação de nós e de ligações para nós já existentes ou novos; e, finalmente, rastreamento da base que pode ser feito seguindo as ligaçōes e abrindo as janelas correspondentes, procurando na rede por algum conjunto de caracteres ou palavra-chave ou, ainda, navegando através do hiperdocumento usando uma ferramenta de navegação que exibe a rede graficamente.

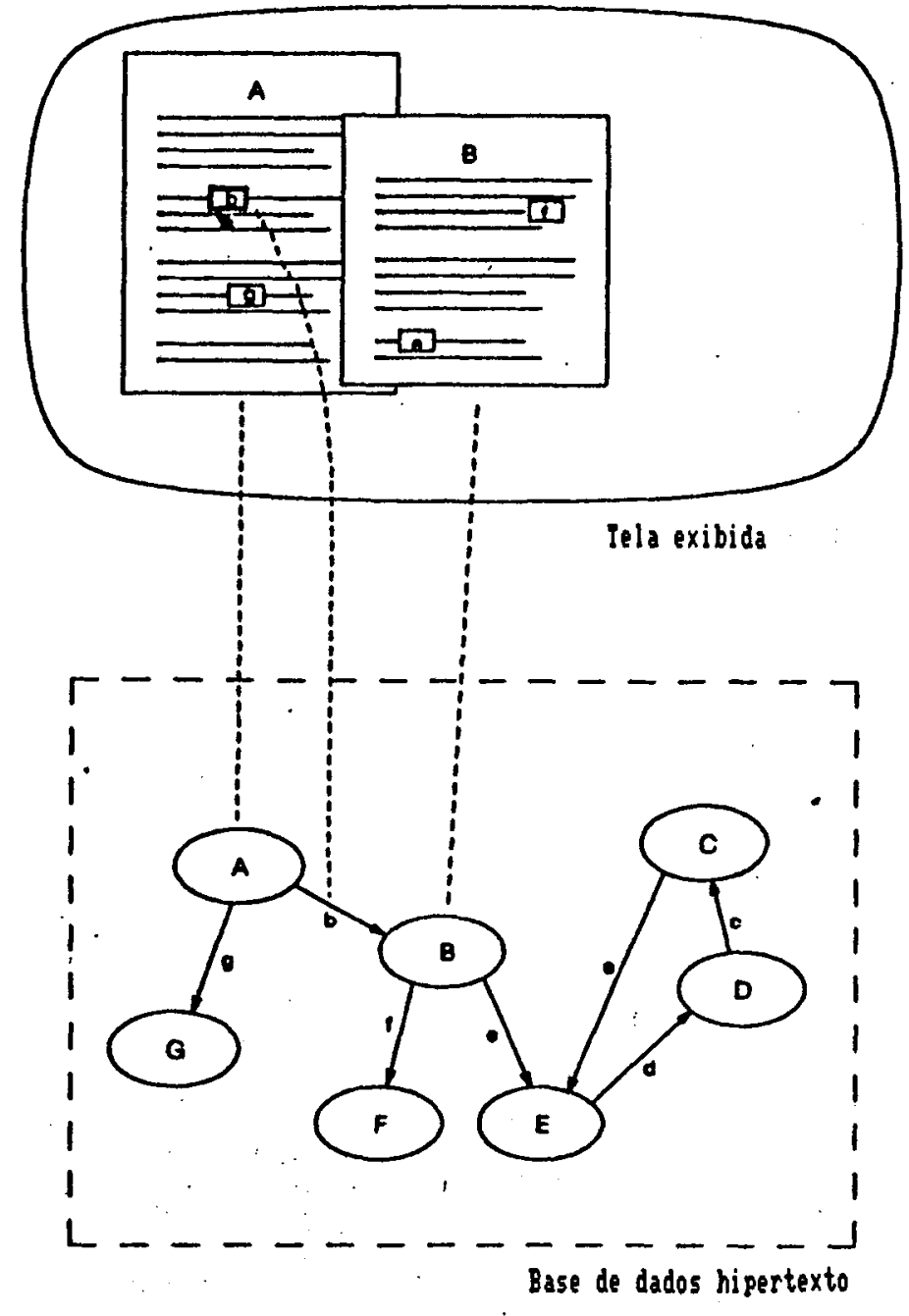

Fig. 2.1 - Associação de Elementos do Hipertexto a Elementos de uma Base de Dados 
O hipertexto permite e encoraja os escritores a fazer referências e, aos leitores tomar suas próprias decisões sobre qual caminho seguir através do hiperdocumento, além de possibilitar que os leitores façam suas próprias anotações sobre o hiperdocumento. Essas anotações são salvas separadamente do hiperdocumento referenciado. Segundo Conklin, isto é possível através das ligações que os sistemas de hipertexto fornecem. As ligaçōes devem levar o usuário a um novo trecho do hiperdocumento pelo simples toque de um par de teclas ou de movimentos do mouse e o transporte deve ser quase instantâneo e se não o for, o usuário deve receber indicações de quanto tempo será necessário esperar se seguir por aquela referência.

As ligações podem conectar uma referência do documento para ele próprio, comentários ou anotações para o texto, dois textos consecutivos ou um trecho de texto e todos seus sucessores imediatos e ainda conectar dados de uma tabela ou figura com sua descrição ou com outra tabela ou figura. As ligações podem fornecer informação organizacional e terem nomes e tipos.

Ainda segundo Conklin, há duas maneiras de se ligar dois pontos do hipertexto explicitamente: por referência ou por organização. As ligações por referência têm duas extremidades e ou vão numa única direção ou permitem retorno. A extremidade origem pode ser um ponto ou uma região do texto, a extremidade destino pode ser também um ponto ou uma região.

É comum encontrar a extremidade origem como sendo um ponto, isto é, um ícone indicando a presença da ligação através de seu nome ou tipo, e a extremidade destino como sendo uma região, isto é, um cojunto contínuo de caracteres exibidos como uma região única. $O$ contrário traz problemas, isto é, se a origem for uma região, como destacar a parte a ser selecionada da região pelo usuário para se chegar ao destino? E como destacar regiōes origens que se sobreponham? 
Já as ligaçōes por organização diferem das ligações por referência pela implementação hierárquica da informação, conectando um nó pai com um nó filho.

Os nós do hipertexto expressam conceitos e idéias, podem ser tipados, isto é, podem ter um título, uma descrição, cor e tamanho para ajudar a determinar o estilo da informação contida nele. Os tipos ajudam a classificar os nós ou definir operações especializadas, segundo Hall e Papadopoulos.

$O$ acesso às informaçōes num sistema de hipertexto pode ser feito por navegação ou recuperação através de palavra chave. De acordo com Hall e Papadopoulos, em [Ha90], a navegação é considerada o principal meio de acesso às informacões. $O$ usuário move-se através da estrutura seguindo as ligações de um nó para outro, decidindo a cada passo qual ligação seguirá, baseando-se na informação localizada no ícone da ligação e também no conteúdo do nó exibido na tela.

Entretanto, Nielsen, em [Ni90], afirma que um dos maiores problemas no uso de hipertexto é o risco de desorientação do usuário enquanto navega no espaço da informação. Também Hardman, em [Ha89], comenta sobre a desorientação do usuário. Para auxiliar o usuário, alguns sistemas de hipertexto oferecem um browser, que é uma ferramenta que auxilia o usuário a determinar sua posição na rede do hipertexto apresentando-a graficamente. O usuário, assim, terá a noção da estrutura do hipertexto (Fig. 2.2). Outra possibilidade também apresentada por Nielsen e Hardman é a disponibilidade de retorno, principalmente para os usuários novatos. Geralmente os usuários tendem a retornar para pontos conhecidos de situações que eles não têm controle ou não possam manipular e, então, recomeçar o trabalho.

Em alguns sistemas como o descrito por Hardmam, em [Ha89], esse auxílio é implementado através de uma tecla que retorna imediatamente à tela de início do hipertexto, enquanto em outros, a cada acionamento da tecla de retorno o usuário vai visitando os nós por que passou até chegar o ponto em que está na ordem inversa. Outros sistemas, como é citado por Hall e Papadopoulos em [Ha90], 
apresentam um caminho pré-definido para o usuário seguir, principalmente se for iniciante. Ele servirá de introdução guiada. Outros ainda permitem que os usuários criem e salvem caminhos padrões no hipertexto.

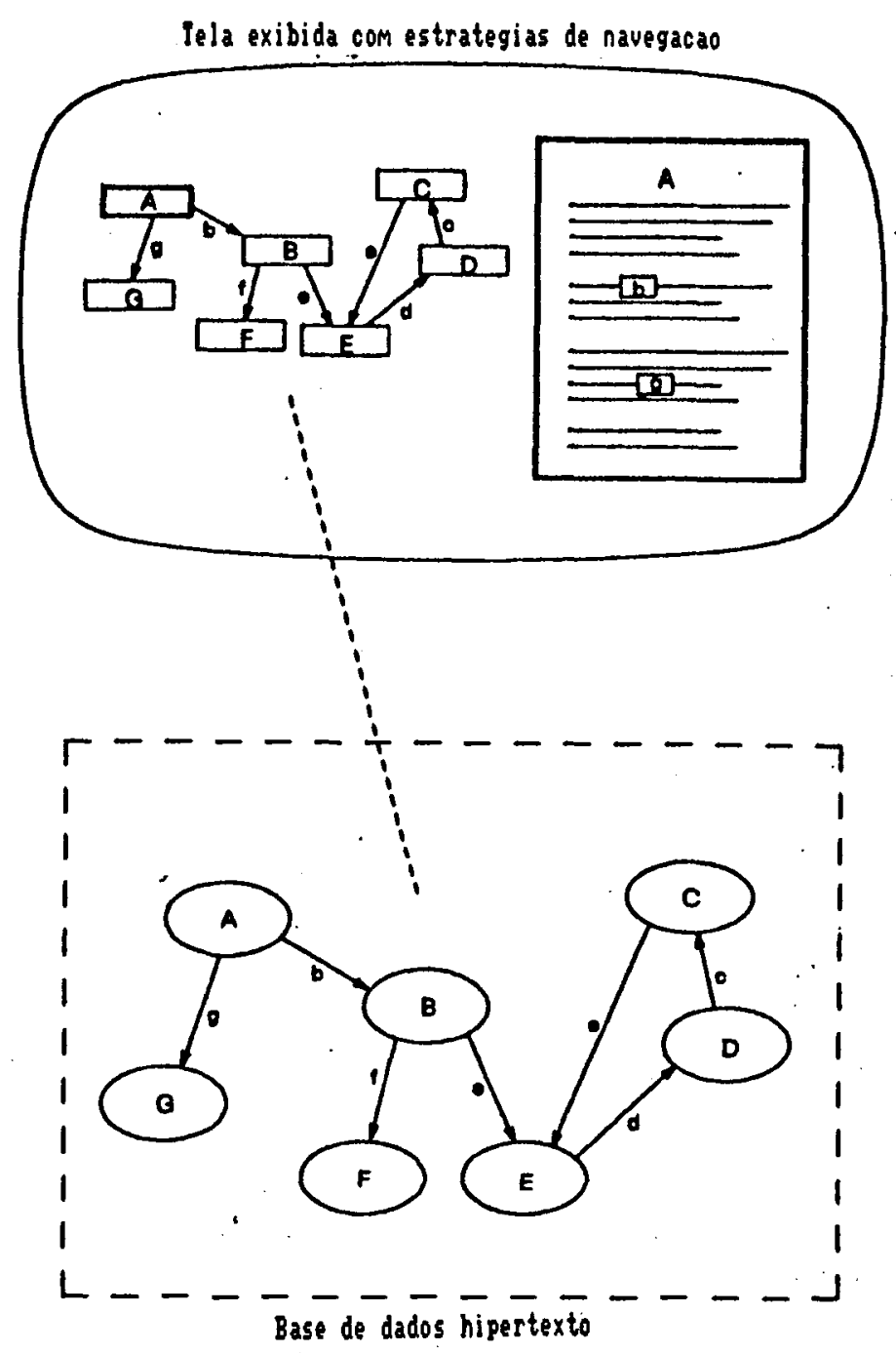

Fig. 2.2 - Browser de um Sistema de Hipertexto

Marchionini e Shneiderman, em [Ma88], afirmam que as estratégias de navegação são atrativas para os usuários, mas ineficientes para recuperação de fatos. Afirmam também que estratégias analíticas que usam conectores lógicos $O R$ e AND e se apoiam em indexação para fornecer a recuperação, devem ser 
fornecidas pelos sistemas de hipertexto. As características de busca, como: os conectivos booleanos; os conjuntos de caracteres, isto é, série de palavras dentro da qual os termos de indagação precisam ocorrer; o escopo da busca; e o truncamento facilitam o rápido acesso à informação. Entretanto, causam uma carga cognitiva adicional da parte do usuário e de um substancial pré-processamento da própria base de dados. E necessário, apesar das dificuldades, estabelecer um equilíbrio entre as estratégias de busca navegacional e analítica.

Em poucos anos, os sistemas de hipertexto têm se tornado populares, entretanto nem todas as aplicações beneficiam-se da organização do hipertexto e nem todas as versões em hipertexto são igualmente fáceis de serem navegadas. De acordo com Furuta e outros, em [Fu89], o projetista precisa ser cuidadoso na identificação de fontes que sejam apropriadas à conversão para o hipertexto. Há algumas regras que podem ser consideradas para se decidir se a conversão é garantida: ter-se um grande corpo de informação organizada em numerosos fragmentos, os fragmentos relacionarem-se entre si e o usuário necessitar somente de uma pequena fraçāo de informação por vez. As atas de congregaçōes, como se verá, seguem essas regras.

A criação de um hiperdocumento envolve duas atividades separadas, mas interrelacionadas: (a) a geração de fragmentos individuais na base de dados do hipertexto, cada um com sua própria estrutura interna e, (b) a identificação dos interrelacionamentos entre os vários fragmentos, isto é, a formação das ligações.

Conforme Hall e Papadopoulos, em [Ha90], um editor é a ferramenta básica para a criação e manutençāo dos nós e ligaçōes, para a modificação da informação contida nos nós e para a modificação da estrutura do hiperdocumento. Muitos sistemas dão acesso a editores de texto padrão que são usados para o preenchimento do nó com o texto. Outros incorporam um editor específico que 
trata o nó como um buffer de edição. As ligações são introduzidas mais tarde para conectar o nó recente com outro por um comando de construção de ligação.

Já Furuta e outros, em [Fu89], consideram que se a estrutura básica de um documento contém muitos pedaços relativamente pequenos que relacionam-se entre si, então há uma forte possibilidade de que a importaçâo automática do documento, com a construção automática de ligaçōes, seja possível. São discutidos quatro casos de estudo, onde a extração da estrutura do documento original é a principal consideração para o desenvolvimento da conversão automática. $O$ reconhecimento da estrutura se torna mais difícil na falta de marcadores, isto é, de símbolos no documento para identificar títulos, secções, parágrafos, etc. Documentos que apresentam uma estrutura mais regular e limitada facilitam o desenvolvimento de uma conversão inteiramente automática.

Num dos estudos de caso trata-se da conversão de oito artigos científicos para o formato hipertexto. Os artigos foram, originalmente, escritos independentemente para publicação em períodicos numa forma linear, com o mínimo de referência cruzada. Foi necessário que o projetista, de seu ponto de vista, adicionasse ligações entre os tópicos que foram cobertos pelos vários artigos. Somente partes da conversão puderam ser automatizadas, sendo que a conversão de outra coleção de artigos requererá uma quantidade similar de esforços. A conversão automática parece não ser vantajosa nesse caso, o melhor seria o autor escrever diretamente os textos num sistema de hipertexto.

Os outros três casos apresentam estruturas mais regulares e apesar de alguns problemas, foi possível uma conversão completamente automática. Um trata de um catálogo de cursos, onde a informação é dividida em: nome, número, pré-requisitos, etc., isto é, consiste de um número discreto e relativamente pequeno de unidades. Outro trata de uma lista de resumos de relatórios técnicos produzidos por uma universidade, onde cada resumo tem um número, título, autores e uma descrição. 
Finalmente, o terceiro trata de uma coleção de microfichas de resumos de dissertações subdivididas em nome do autor, instituição, título e descrição. Em cada um desses casos, a informação consiste de um número discreto e relativamente pequeno de unidades. Os documentos apresentam características, como por exemplo um símbolo antes do título, que tornam fácil a identificação da unidade de informação. Neste caso, os programas de conversão poderiam ser reutilizados para outros catálogos de cursos, outras listas de relatórios técnicos ou de resumos de dissertações similares.

Streitz e outros, em [St90], discutem a aplicação do hipertexto para o aprendizado, dirigindo-se principalmente para as ferramentas oferecidas ao autor para criar o hiperdocumento. Nesse sentido, os sistemas de hipertexto devem integrar-se a bases de conhecimento sobre o autor e a estrutura semântica do documento. Isto implica que a arquitetura da ferramenta de autoria deve incluir componentes que permitam a monitoração e análise das atividades do autor.

Eles apresentam um sistema - SEPIA: Structure Elicitation and Processing of Ideas for Authoring - , que acreditam, representará a principal porção da funcionalidade esperada pelas ferramentas de autoria no futuro. Tal sistema, ainda em desenvolvimento, objetiva a construção de um sistema cognitivamente adequado, baseado em resultados derivados de modelos sobre processos cognitivos no ato de escrever e na solução de problemas. E, ainda, objetiva um sistema ativo.

\subsection{Aplicações de Hipertextos}

Atualmente pode-se verificar o desenvolvimento de diferentes sistemas de hipertexto que podem apoiar uma grande variedade de aplicações e usuários. Conklin, em [Co87], organiza os vários sistemas de acordo com sua aplicação e para 
isso considera quatros áreas de aplicações para as quais os sistemas têm sido desenvolvidos: sistemas literários ou bibliotecas on-line, ferramentas para exploração de problemas, sistemas de navegação e sistemas de propósito geral. A seguir são descritas essas áreas em termos de suas características, sistemas de hipertextos mais adequados e exemplos.

\section{Sistemas Literários}

Os sistemas literários fornecem um ambiente no qual grandes volumes de informação podem ser acessados e mantidos através de uma interface de usuário simples para uso simultâneo pelos usuários. Nessa área encontram-se os sistemas Textnet e Xanadu.

De acordo com Conklin, Textnet, desenvolvido por Randall Trigg como trabalho de tese, com sua própria tese escrita nele, implementa dois tipos básicos de nós: aqueles com conteúdo textual e aqueles que hierarquicamente organizam outros nós. O sistema apoia uma taxonomia de tipos de ligações (mais de oitenta tipos), que serve para enriquecer o significado da informação. Através do uso de ligações tipificadas, o sistema permite que o usuário atribua críticas e outras formas de comentários como novos nós a nós já existentes. Tais ligações podem ser de

apoio e de refutação, além de poderem ser descrições. É possível, a autores e usuários, definir vários caminhos através da mesma rede de informação. Aos usuários, ainda, podem ser fornecidos caminhos padrões através do hiperdocumento e os nós visitados podem ser armazenados para serem usados mais tarde ou darem a outros usuários um caminho similar através do hiperdocumento.

O projeto Xanadu, também incluido na área de sistemas literários, foi desenvolvido por Ted Nelson e tem por objetivo ser o principal veículo de publicação no futuro, possibilitando armazenamento, recuperação e revisão 
contínua de documentos eletrônicos ligados, servindo milhōes de usuários simultaneamente com hipertexto, gráfico, audio e vídeo. Ele estabelece uma forte separação entre a interface de usuário e a base de dados, possibilitando maneiras de manutençāo de direitos de cópia e fornecendo facilidades para a distribuição de direitos de propriedade. Atualmente está sendo implementado em Unix e deverá rodar em estaçōes de trabalho Sun.

\section{Sistemas para Exploração de Problemas}

$\mathrm{Na}$ área de sistemas para exploração de problemas, encontram-se sistemas altamente interativos, fornecendo respostas rápidas e uma coleção de comandos para manipulaçāo da informação. Essa área poderia, ainda, ser subdividida em sistemas de hipertextos que apoiam a ação de escrever em grupo ou não e que apoiam a programação de sistemas.

We, Writing Environment, é um sistema feito especificamente para apoiar a ação de escrever e foi desenvolvido por um grupo da Universidade da Carolina do Norte. De acordo com Hall e Papadopoulos, em [Ha90], no sistema We, o hiperdocumento é tratado com um estágio anterior no desenvolvimento do documento em papel. Ele ajuda os escritores a transformarem suas idéias, ainda desconexas, numa estrutura hierárquica e então escreverem um documento de acordo com esta estrutura.

Delisle e Schwartz, em [De89], descrevem os sistemas de hipertexto como ferramentas voltadas para a ação de escrever, isto $\tilde{e}$, seu apoio tanto no desenvolvimento de documentação técnica impressa como no desenvolvimento de hiperdocumentos, onde o meio de elocução é o hipertexto. Ainda abordam o problema de várias pessoas colaborando para a composição de um documento. Para 
isso consideram os sistemas de hipertexto NoteCards e Neptune, que não foram desenvolvidos objetivando esse fim mas oferecem características para tal.

A ação de escrever um documento envolve as seguintes atividades: registro das idéias relevantes, exploração de relacionamentos entre as idéias, estruturação das idéias e preparação do documento. $O$ hipertexto pode apoiar cada uma dessas atividades. Cada nó de um sistema de hipertexto pode registrar uma idéia e numa fase inicial se registraria todas as idéias interessantes sobre o que se deseja escrever.

O relacionamento das idéias pode ser representado pelas ligações entre nós permitidas por qualquer sistema de hipertexto. Numa segunda fase, então, essas relaçōes poderiam ser estabelecidas auxíliando o autor, que aumentaria seu discernimento através das várias visões dos relacionamentos de diferentes perspectivas. Normalmente a estruturação hierárquica em documentos técnicos é conseguida pelas ligações que interconectam os nós representando seçōes, subseções, parágrafos e figuras do documento. Quando o documento está pronto para a impressão, os conteúdos dos nós são extraídos na ordem apropriada. Apoios mais avançados para a preparação de documentos podem incluir manutenção automática de referências e de bibliografias.

A composição de um documento técnico pode ser uma atividade realizada por várias pessoas: autores, revisores, editores, ilustradores, desenhistas e outras. Os sistemas de hipertexto também apoiam a ação de escrever em colaboração, através de acesso distribuído; gerenciamento de transação, assegurando que mais de um autor não tente atualizar ao mesmo tempo a mesma porção da base de dados do hipertexto e que os dados permaneçam válidos face a problemas externos; mecanismos de controle de acesso; e mecanismo de notificação de atualização para alertar os leitores que o que eles estão lendo está sendo atualizado.

O sistema de hipertexto Neptune, desenvolvido para apoiar a colaboração em projetos de engenharia, pode, também, apoiar um grupo de autores trabalhando 
num grande documento técnico. Cada autor fica responsável por uma porção do documento, Contexts, e faz as modificaçōes que achar conveniente. Neptune faz, automaticamente, com que essa porção, enquanto o autor está trabalhando, seja acessada por outros autores unicamente para leitura. E depois das modificações completadas, a operação merge instala as novas versōes na porção principal.

O desenvolvimento do sistema NoteCards, de acordo com Conklin em [Co87], objetivava, inicialmente, ser uma ferramenta de apoio às informações de um analista, auxiliando na coleta da informação e na produção de relatórios analíticos. Entretanto, tem sido usado para a ação de escrever, programação, gerenciamento de informaçōes pessoais, projetos de engenharia e principalmente como um veículo para estudo de hipertexto. Como apoio à ação de escrever, de acordo com Delisle, ele apresenta características que contribuem para essa atividade: exploração e expressão de idéias; inclusão de comentários, críticas e questōes sobre o documento sendo escrito; e convenções e regras para serem seguidas na escrita do documento, por exemplo, como usar nós e tipos de ligaçōes.

Os sistemas de hipertexto, como já dito, também podem ser explorados como meios de elocução de documentos. Os hiperdocumentos dão liberdade para os leitores explorarem os tópicos que forem de seus interesses. Algumas aplicações desenvolvidas são enciclopédias eletrônicas, sistemas de ajuda on-line e livros de referências médicas e jurídicas. Frequentemente a estrutura é hierárquica e a ordem linear, por não ser evidente, deixa o leitor livre para escolher qualquer caminho através do documento, as ligações servem para expressar as organizaçōes ou referências.

Os sistemas de hipertexto, conclui Delisle, em [De89], surgem como ferramentas efetivas para escritores, apoiando a coleta e organização da informação para a preparaçāo do documento tanto em papéis como em hiperdocumentos, além de oferecerem facilidades para a sua composição em colaboraçāo. 
Ainda sobre sistemas para exploração de problemas e entre os que apoiam a programação de sistemas, destaca-se o sistema de hipertexto gIBIS, graphical Issue Based Information Systems, descrito por Conklin e Begeman em [Co88]. IBIS foi projetado para apoiar o processo de projeto de programas complexos que não podem ser solucionados pela abordagem tradicional da análise de sistemas e onde a conversação entre os participantes do projeto $\hat{e}$ fundamental.

Bigelow, em [Bi88], descreve o sistema Neptune, já citado anteriormente e caracterizado por Conklin como um sistema de hipertexto para navegação, também, para apoiar a engenharia de software. Deslile, em [De86], já o descreve, de modo geral, para apoiar projetos assistidos por computador que podem incluir projetos de engenharia elétrica, engenharia de software e outros. Deslile exemplifica usando o sistema Neptune para apoiar a engenharia de software.

Tanto Bigelow como Deslile usam o nó para representar os componentes do projeto que incluem os requisitos e as especificações, o projeto e a documentação, os códigos fonte e objeto, as especificações do teste e resultados e a documentação do usuário. As ligaçōes representam as relações entre os componentes. Através dos atributos e pares de valores ilimitados que cada nó e ligação pode ter, é possível descrever o que um nó representa e qual relacionamento uma ligação descreve. Por exemplo, imagine um módulo 1 que chama um módulo 2. Os módulos representados por nós podem ser ligados por uma ligação que tenha atributo "Chama Módulo". Além disso, o sistema Neptune fornece um acesso distribuido numa rede de computadores, um acesso multiusuário com recuperaçāo de transações incompletas ou interrompidas e um rápido acesso a histórias completas de todas as versões das informações armazenadas na base de dados. 


\section{Sistemas para Navegação}

A navegação, outra aplicação de sistemas de hipertexto, através de grandes volumes de informação por pessoas com diferentes necessidades e experiências, talvez seja a mais importante aplicação de hipertexto e a mais extensamente usada, de acordo com Hall e Papadopoulos, em [Ha90]. Esses sistemas de navegação podem ser usados numa variedade de aplicações, tais como enciclopédias on-line, treinamento assistido por computador, manuais de referências, peças expostas em museus e outras.

Os sistemas de navegação, de maneira geral, diferenciam o autor do leitor. Normalmente o hiperdocumento é criado por um pequeno número de autores especialistas no assunto e o espaço da informação é explorado por um grande número de diferentes leitores. $\mathrm{O}$ acesso às ferramentas de manutenção é restrito aos autores. Os leitores podem somente examinar mas não modificar a base de dados, entretanto, alguns sistemas fornecem ferramentas para os leitores fazerem seus próprios comentários e anotações, que são salvos em arquivos separados. Alguns sistemas desenvolvidos que enfatizam a navegação são: Zog/KMS, Hyperties, Guide, Symbolics Document Examiner e HyperCard.

De acordo com Conklin, Zog foi desenvolvido em 1972 na Universidade de Carnegie-Mellon com o objetivo particular de servir simultaneamente a uma comunidade de usuários operando em sistema de tempo compartilhado. Em 1981 foi desenvolvido o sistema KMS, Knowledge Management System, por Donald McCracken e Robert Akscyn, dois projetistas do Zog, e em 1982 foi usado como um sistema de gerenciamento de informaçāo no porta-aviōes nuclear USS CARL VINSON. A base de dados do Zog/KMS constitui-se de segmentos chamados frames. Um frame tem uma linha título no topo da tela e algumas linhas de texto 
com resultado ou assunto e um conjunto de opções para interconectar os frames e uma linha de comandos padrão.

O sistema Hyperties foi desenvolvido na Universidade de Maryland visando a ser uma ferramenta prática e fácil de ser aprendida para navegar na base de dados. Sua base de dados consiste de um conjunto de pequenos artigos, sua unidade básica, relacionados com outros por ligações que são exibidas ao usuário para serem selecionadas como um conjunto de caracteres luminosos dentro do próprio corpo do artigo (menus embutidos). Cada artigo, por sua vez, é subdividido em três campos: título, um pequeno conjunto de caracteres nomeando o artigo; definição, uma pequena frase descrevendo o artigo; e o corpo do artigo. Foi usado por Furuta e outros em quatro trabalhos descritos em [Fu89]. Os trabalhos, já comentados no ítem anterior, referem-se à conversão de oito artigos científicos, um catálogo de cursos, uma lista de resumos de relatórios técnicos e uma coleção de microfichas de resumos de dissertações para o formato hipertexto. Furuta discute os aspectos da conversão automática e quanto a isso não se pode dizer que todos são apropriados. Entretanto bases de dados hipertexto fornecem fácil acesso e manipulação.

Também usando Hyperties para a navegaçāo, foi desenvolvida uma aplicação para museus, instalada atualmente em três. Shneiderman e outros, em [Sh89], analisam o uso do sistema de hipertexto pelos visitantes nos museus considerando os artigos acessados, o tempo gasto em cada um, o número de vezes que $\mathrm{o}$ índice foi acessado, etc. $\mathrm{O}$ resultados mostraram que os visitantes de todos os museus usaram os menus embutidos do Hyperties para ir de um artigo para outro mais do que a abordagem tradicional de índices. $O$ estudo demonstrou, também, a praticabilidade do uso de base de dados interativas em conjunto com o que os museus. E os elaboradores da exibição, com a base de dados no computador, podem fornecer informações detalhadas, variar os níveis de apresentação, oferecer várias línguas ou permitir ao responsável pelo museu explorar uma imensa base de dados. 
Guide, o primeiro sistema de hipertexto implementado em computadores pessoais, foi desenvolvido por Peter Brown na Universidade de Kent e é hoje comercializado pela Office Workstations Limited (OWL). Encontra-se em versões disponíveis para estações de trabalho Sun e microcomputadores Apple, Macintosh, IBM e compatíveis.

De acordo com Hall e Papadopoulos, Guide usa três tipos de ligações, que quando são ativadas fazem com que o texto visto na janela seja completamente substituído pelo texto apontado pela ligaçāo (replacements links); exibem o texto apontado numa janela pop-up (note links); e trazem uma nova janela com o texto apontado (reference links). $\mathrm{O}$ sistema Guide tem sido aplicado na industria e educação. A Renault tem um manual de manutenção construído sobre o Guide, assim como a Aldus Corporation, que usa o Guide para criar um sistema de auxílio para o PageMaker, um sistema de publicação eletrônica.

HiperCard é um sistema de hipertexto similar ao NoteCards e foi usado por Hardman, em [Ha89], para implementar um sistema de auxílio a turistas ou moradores da cidade de Glasgow para se orientarem sobre localizações de ruas, lojas, restaurantes, hotéis, cinemas e etc, diárias de hotéis, transporte por trem, metrô e ônibus e várias outras informações.

\section{Sistemas de Propósito Geral}

Os sitemas de propósito geral são aqueles desenvolvidos com o objetivo de se experimentar o hipertexto enquanto tecnologia, isto $e$, qual a melhor interface, representação da base de dados, etc. São usados para a ação de escrever, a programação, o gerenciamento de informaçōes pessoais, projetos de engenharia e outros. Nessa área destacam-se NoteCards, Intermedia, Neptune e Boxer. 
NoteCards, já descrito anteriormente para apoiar a ação de esrever, é um sistema desenvolvido pela Xerox Parc com o objetivo inicial de servir como uma ferramenta de apoio às informações do analista, auxiliando-o numa melhor análise. Entretanto, uma interface programada torna-o uma arquitetura aberta, que permite ao usuário construir novas aplicações. A tarefa de criação de novos tipos de nós é facilmente realizada e vários usuários podem trabalhar ao mesmo tempo no mesmo NoteFile.

O sistema Neptune, também já descrito anteriormente para apoiar a ação de escrever, separa fortemente o front end, uma interface de usuário baseada em Smalltalk, do back end, um servidor baseado em transações chamado Hypertext Abstract Machine. A interface fornece vários sistemas de navegação (browsers) permitindo visões de subgrafos de nós e suas ligaçōes, navegação pelas estruturas de nós e ligaçōes hierárquicas e acesso a nós individuais no hiperdocumento. $O$ servidor é um modelo genérico de hipertexto que fornece operaçōes para criação, modificação e acesso a nós e ligações.

De acordo com Conklin, o sistema Intermedia, desenvolvido na Universidade de Brown - Institute of Research in Information and Scholarship (IRIS), teve como base três gerações anteriores de sistemas de hipertexto e duas décadas de trabalho. O primeiro sistema foi o Hypertext Editing System projetado por Ted Nelson e usado por Houston Manned Spacecraft Center para produzir a documentação do foguete Apollo. O segundo foi o File Retrieval and Editing System, que caracterizou-se por ligações hierarquicamente dinâmicas e bidirecionais, múltiplas janelas e gráficos vetorias em terminais gráficos. Chegou a ter como usuário uma classe poética inglesa que fazia todas as suas escritas e leituras num documento compartilhado de hipertexto. E, finalmente, o Eletronic Document, um sistema de hipermedia (uma extensão de hipertexto que incorpora 
outros recursos, como gráficos estáticos, gráficos animados, vídeo e som, em adição ao texto) enfatizando auxílio a gráficos coloridos e navegação.

O sistema Intermedia, de acordo com Yankelovich e outros, em [Ya88], foi desenvolvido para apoiar o ambiente de ensino e pesquisa de uma universidade. Com ele, instrutores podem construir ambientes a serem explorados por seus estudantes, assim como aplicações para serem usadas no trabalho do dia-a-dia, nas pesquisas e na escrita. Ele fornece uma coleção de ferramentas que permite aos autores criarem ligações para documentos como textos, diagramas, imagens geradas por computador, vídeo e música. Constitui-se de: um processador de texto (InterText); um editor gráfico (InterDraw); um editor de linha que permite ao usuário organizar a informação em seqüências de tempo e data (InterVal); um visualizador de objetos em três dimensões (InterSpec); um editor de imagens obtidas por varredores ópticos (scanner) (InterPix); e métodos complexos para filtragem do documento, criação e rastreamento de trilhas. De acordo com Yankelovich e outros, também é uma ferramenta que apoia um ambiente no qual programadores podem desenvolver aplicações consistentes, usando técnicas de programação orientada a objetos e blocos reusáveis.

\subsection{Sistemas para Apoio a Reuniões}

As reuniōes são usadas para qualquer tarefa intelectual que requer a coordenação ou o acordo de várias pessoas. Elas podem ser de trabalho, onde as pessoas se reunem para definir um novo projeto, expor etapas realizadas e delinear novas etapas, como por exemplo, equipes de desenvolvimento de sistemas que periodicamente se reúnem para integrar e gerenciar os documentos produzidos e usados ao longo do ciclo de vida de um sistema. As reuniões, também, podem ser de 
deliberação, onde as pessoas se reunem para discutir vários assuntos e até mesmo realizar eleições, como por exemplo, reuniões de conselhos de organizações.

Qualquer que seja o tipo de reunião, é conveniente que se tenha algumas ferramentas para auxiliar a interação do grupo. De acordo com Stefik e outros, em [St87], as lousas, documentos e pessoas fazendo anotações manuais são frequentes em reuniões. A lousa permite o registro de idéias e a possibilidade de realocar textos e figuras, entretanto o espaço é limitado e o rearranjo é inconveniente, pois é necessário apagar e reescrever, além de ser, às vezes, ilegível. Os documentos precisam estar em ordem de discussão e se por acaso isso muda, a procura pode tornar-se difícil.

E conveniente, então, que o computador substitua as várias ferramentas, pois muitas funções, que são desagradáveis ou impossíveis com as ferramentas descritas, seriam facilmente implementadas com computadores. Os sistemas de janelas e auxílios para desenho, por exemplo, poderiam ser usados no lugar das lousas com maior flexibilidade no rearranjo dos textos e figuras, podendo-se, ainda, reproduzir os textos e figuras em papel, transparências, etc. Os sistemas de arquivos tornam possível a recuperação de informações geradas em outras reuniōes, a revisão dos argumentos e a exibição de uma série histórica dos mesmos.

Sarin, em [Sa85], descreve um sistema, RTCall, que permite aos participantes, de maneira síncrona, trocar informaçōes de uma base de dados de calendário pessoal para marcar uma futura reunião. Os participantes usam computadores pessoais a partir dos quais têm uma visāo de seus calendários pessoais e uma visão de um calendário geral compartilhado por todos. O sistema trabalha em tempo real, mantendo consistente as visōes por meio de troca de mensagem por uma rede local.

Já Stefik e outros, em [St87] desenvolvem um projeto, Colab, onde implementam duas ferramentas de computador para apoio a reuniōes face-a-face, 
que são Cognoter e Argnoter. As ferramentas são usadas numa sala experimental de reuniões e direcionadas a pequenos grupos de trabalho, 2 a 6 pessoas, e com computadores pessoais conectados numa rede local. $O$ objetivo é tornar as reuniōes mais eficientes e fornecer uma oportunidade para a condução de mais pesquisas sobre reuniões assistidas por computador.

Cognoter é uma ferramenta usada para preparar apresentações coletivamente. Sua saída é um esboço de idéias e textos associados, sendo similar ao sistema de hipertexto NoteCards. Cognoter organiza uma reunião em três fases distintas: armazenamento, organização e avaliação. A primeira fase envolve a geração inicial de idéias: cada participante, através de seu equipamento, digita um título ou frase que representa sua idéia, podendo, ainda, entrar com um texto explicativo. Nessa fase não se pode avaliar ou eliminar nenhuma idéia, pois não se pode afirmar que a idéia não faz sentido, ela ainda não foi comparada com as outras.

$\mathrm{Na}$ fase de organização o grupo tenta estabelecer uma ordem nas idéias geradas e para isso liga as idéias numa ordem de apresentaçāo e, ainda, pode agrupá-las em subgrupos. A ligação é normalmente acompanhada por alguma discussão verbal e é indicada visualmente por setas entre os ítens que exprimem as idéias.

$\mathrm{Na}$ terceira fase, a de avaliação, determina-se a forma final de apresentação. Os participantes revêem a estrutura geral, preenchem os detalhes e, então, eliminam idéias irrelevantes, pois nessa fase se tem certeza de que realmente a idéia não serviu.

Numa reunião apoiada por Argnoter, a outra ferramenta do projeto Colab, os participantes já vêm com uma proposta de algo a ser feito e, portanto, já gastaram energias pensando sobre ela. A reunião, compreendida nas fases de proposiçāo, argumentação e avaliação, objetiva escolher a melhor proposta. $\mathrm{Na}$ fase 
de proposição, as propostas criadas e exibidas em janelas na tela, que podem ser privadas ou públicas, têm um texto descritivo, um esquema e um nome.

$\mathrm{Na}$ fase de argumentação cada participante apresenta razões para a escolha ou não de cada proposta individual. As razões são escritas como declaraçōes embaixo da respectiva proposta. As declarações podem ser pró e contra e sāo formuladas cuidadosamente, já que todos os participantes poderão vê-las. É possível, nessa fase, caracterizar as declarações em termos de compatibilidade, custo, tempo de desenvolvimento, eficiência, praticabilidade, simplicidade e utilidade. E com apoio computacional, é possível, automaticamente, criar tabelas auxiliares que comparam as propostas com base nessas características.

$\mathrm{Na}$ fase de avaliação, é possível visualizar a estrutura dos argumentos em termos das ligações entre declarações que dizem a mesma coisa. E como os participantes frequentemente discordam da validade das declarações, é possível modelar essas diferenças em conjuntos de opiniōes. Esses conjuntos contém válido ou inválido para cada declaração. Dessa maneira Argnoter age como uma planilha eletrônica de argumentação, onde cada proposta é vista e avaliada em relação a conjuntos específicos de opiniōes. Entâo, a proposta exibida é gerada ao se passar pelos argumentos sobre a proposta, procurando as declaraçōes conectadas e então exibindo-se os argumentos que são apoiados pelo conjunto de opinião. Vários conjuntos de opiniões podem coexistir e qualquer participante é capaz de criá-lo. Uma proposta pode ser exibida considerando-se diferentes conjuntos de opiniões.

O projeto Colab, enfim, produz uma sala de reuniōes e várias ferramentas operacionais, objetivando o desenvolvimento e o entendimento de sistemas de apoio a reuniōes.

Ellis e outros, em [El91], descrevem um novo campo multidisciplinar: Trabalho em Cooperação Assistido por Computador ou Groupware, que abrange sistemas de computador que integram o processamento de informação e atividades 
de comunicação. Ao preparar um documento, consultar uma base de dados ou até jogar, o usuário está interagindo unicamente com o computador. Até sistemas projetados para aplicaçāo multi-usuário, tais como sistemas de informação de escritórios, fornecem um mínimo apoio para a interação usuário-a-usuário. Este tipo de apoio é, claramente, necessário, já que uma porção significativa das atividades de uma pessoa ocorre em grupo.

Ellis apresenta o sistema Grove, um editor de texto projetado para o uso por um grupo de pessoas editando, simultaneamente, o esboço de um documento, durante uma reuniāo formal ou uma discussão informal de um grupo de trabalho. As reuniões ou discussões, com esse sistema, podem ser face-a-face, com os participantes em estações de trabalho; distribuídas, onde cada participante participa estando em seu escritório com seu equipamento; e podem misturar os dois tipos, isto é, alguns participantes estão face-a-face e outros distribuídos.

A arquitetura usa um editor local e reproduz o documento em cada estação de trabalho de usuário. $O$ sistema Grove permite que qualquer participante possa ver e editar qualquer coisa e não há, no modo padrāo, mecanismos que protejam o documento enquanto alguém edita, isto é, todos podem editar o mesmo documento e até o mesmo parágrafo ao mesmo tempo. Esse editor é o oposto do que se vê em sistemas CASE, que forçam o grupo a trabalhar com módulos protegidos e de uma maneira isolada.

Entretanto, com um editor em grupo, como o do sistema Grove, surgem problemas de tempo de respostas, açōes concorrentes e dados inconsistentes. Por exemplo, uma pessoa pode eliminar uma sentença enquanto outra pessoa insere uma palavra na mesma sentença. Para resolver conflitos entre operaçōes simultâneas dos participantes, que é comum nos sistemas Groupware, é necessário mecanismos de controle de concorrência. $O$ sistema Grove adota a abordagem de transformação de operação. Cada usuário tem sua própria cópia do editor Grove e 
quando uma operação é requisitada, a cópia, no local, executa a operação imediatamente, e, então, transmite a operação adiante com um vetor de estado indicando quantas operaçōes foram processadas recentemente de outras estaçōes de trabalho. Cada cópia do editor tem seu próprio vetor de estado com o qual compara o vetor de estado que chega. Se o vetor de estado recebido e o local são iguais, a operação transmitida é executada como requisitada, senão ela é transformada antes da execução. A transformação específica depende do tipo de operação e das operações já executadas. Apesar de parecer caótico, depois de um período de aprendizagem e treinamento, um protocolo social interpõe-se entre os participantes, permitindo uma harmonia no trabalho.

Ellis também comenta sobre a dificuldade de desenvolver sistemas Groupware com sucesso e que há muito trabalho interessante a ser feito nesse campo.

Os sistemas de hipertexto também podem apoiar o trabalho em grupo. De acordo com Conklin, em [Co87], já em 1960, Douglas Engelbart começava a usar o computador para apoiar o trabalho em grupo e implementou o sistema NLS (oN Line System) permitindo que o computador armazenasse todas as especificações, projetos, documentação, relatórios, notas, referências, etc. de sistemas em desenvolvimento, além de permitir comunicação via consoles. Atualmente o sistema NLS é chamado de NLS/Augment, comercializado pela McDonnell Douglas e, além de oferecer um ambiente para engenharia de software, inclui comunicação assíncrona, a partir das ligaçōes, e síncrona com vários terminais compartilhando uma mesma parte da tela, teleconferência, etc. Inclui, ainda, facilidades para a produção e controle de documentos, organização e projeto de gerenciamento de informação e engenharia de software. Stefik e outros , em [St87], e Ellis e outros, em [E191], destacam o sistema NLS/Augment no apoio ao trabalho em grupo. 
Outro sistema de hipertexto que se destaca nessa área é gIBIS (graphical Issue Based Information Systems). Conklin e Begeman, em [Co88], descrevem um projeto de hipertexto dirigido a fornecer um ambiente a times de projetistas de sistemas no qual todos os aspectos de seus trabalhos podem ser apoiados e intermediados pelo computador. Isto inclui os documentos tradicionais como requisitos, especificações, projeto de alto nível e a documentação do projeto, mas também inclui entrevistas com usuários, revisões de projetos, notas e esboços de projetistas, decisões de projeto, atas de reuniões, etc. A pesquisa é, principalmente, dirigida para o fluxo do processo do projeto, onde a maioria da informação é informal e para a qual há pouco apoio técnico.

gIBIS implementa o método IBIS desenvolvido por Horst Rittel e que baseia-se no princípio que o processo de projeto para problemas complexos é, fundamentalmente, uma conversação entre os projetistas, na qual eles trazem seus respectivos conhecimentos especializados e pontos de vista para a resolução dos problemas do projeto.

No modelo IBIS cada problema (Issue) pode ter muitas posiçōes (positions) que é uma asserção que resolve o problema. Por sua vez, uma posição deve ter um ou mais argumentos (arguments) que apoiam a posiçāo. Cada problema, separadamente, é a raiz de uma árvore com os filhos sendo as posições e os filhos dos filhos sendo os argumentos. Há nove tipos de ligações no IBIS para ligar problemas, posiçōes e argumentos como, por exemplo, uma posição responde-a (responds-to) um problema.

O sistema de hipertexto gIBIS apresenta uma interface dividida em quatro janelas com: um navegador gráfico (Browser), um índice estruturado de nós, um painel de controle e uma janela de inspeção. $O$ navegador fornece uma apresentação visual dos nós e ligaçōes que formam um grafo. Os nós e ligações são exibidos numa tela de tamanho ilimitado virtualmente. $O$ índice de nós fornece uma 
visão hierárquica dos nós. O painel de controle permite criação de nós e ligações, marcação dos nós para leitura ou não, carregamento de um particular grupo de dados para o navegador, buscas, etc. $\mathrm{Na}$ janela de inspeção são exibidos os atributos e conteúdos dos nós e ligaçōes.

\subsection{Avaliação da Bibliografia}

Como visto, hipertexto é, ainda, uma tecnologia muito recente, com muitos problemas a serem resolvidos. Talvez a maior dificuldade na criação de sistemas de hipertexto seja a definição de modelos de dados que possam ser mantidos e não a construção de interface de usuário. Entretanto, muitas aplicações têm sido desenvolvidas com sistemas de hipertexto, tanto com aqueles que já apresentam uma versão comercial como com aqueles que estão em fase experimental. E tem-se obtido sucesso.

Com a bibliografia estudada, pode-se destacar algumas aplicações mais frequentes de sistemas de hipertexto e verificar que elas têm características comuns e que podem ser apoiadas por sistemas de hipertexto de uma maneira geral.

As aplicações mais frequentes têm sido em: (a) projetos assistidos por computador como, por exemplo, engenharia de software e projetos de circuitos elétricos; (b) ensino em várias áreas do conhecimento; (c) "balcão" de informaçōes como, por exemplo, o sistema descrito por Hardman, em [Ha89]; e (c) autoria de documentos.

Essas aplicaçōes apresentam as seguintes características:

- elaboração de vários tipos de documentos,

- documentos podem ser complexos ou não,

- documentos podem ser fragmentados, 
- necessidade de rápido acesso aos diversos documentos,

- revisões de versōes antigas,

- várias pesquisas por diversas chaves de busca,

- participação de uma ou várias pessoas no trabalho,

- trabalho a ser feito pode ser dividido entre diversas pessoas,

- usuário novato e/ou experiente,

- apresentação de textos com palavras e trechos com destaque,

- privacidade no desenvolvimento de partes do trabalho.

Para apoiar todas essas características, os sistemas de hipertexto apresentam:

- texto não linear,

- permissão de autoria,

- recuperação de informações por referências cruzadas,

- recuperação de informações por palavras chaves,

- facilidade de uso,

- permissão de anotações pessoais,

- diferentes visualizações do documento,

- acesso distribuído.

A tabela I relaciona as características, especificamente, de sistemas de apoio a reuniōes com as características de hipertexto citadas acima, mostrando que há possibilidade de usar o hipertexto no apoio a reuniões. 


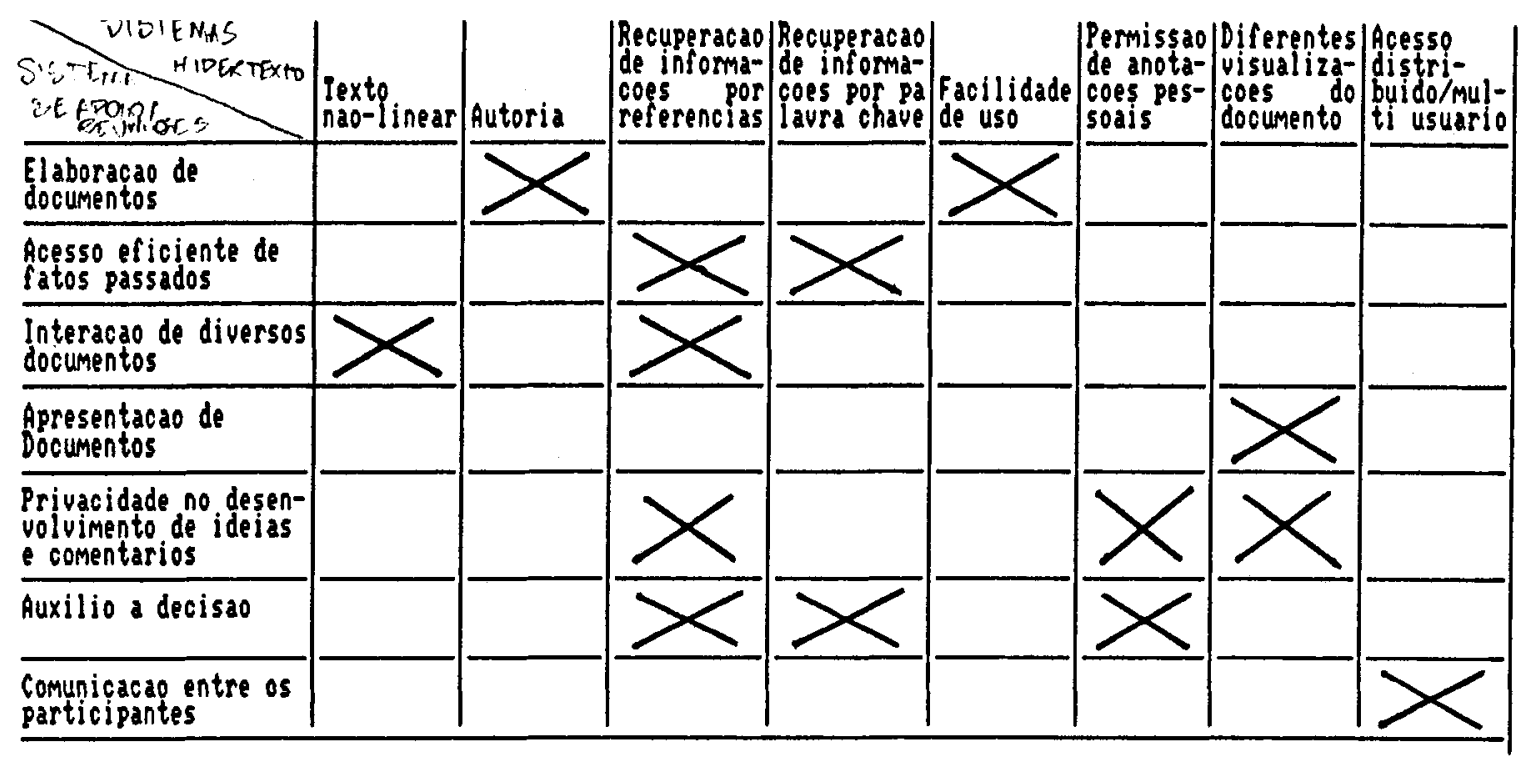

Tabela I - Características de Sistemas de Hipertexto X Sistemas de Apoio a Reuniōes

\subsection{Considerações Finais}

Observando-se a bibliografia, percebe-se o esforço dos pesquisadores para tornar os sistemas de hipertexto eficientes, efetivos e úteis em várias áreas do conhecimento. Esses esforços têm sido recompensados pelo sucesso de diversas aplicações e pela apresentação de sistemas de hipertexto comercializados, aumentando, assim, sua divulgação.

Notam-se, ainda, esforços no sentido de ampliar o uso dos computadores para auxiliar a interação entre usuários, entretanto muito, ainda, precisa ser feito. Pode-se verificar, também, que existe a possibilidade de se utilizar sistemas de hipertexto para essa interação ou para organizar uma série de documentos gerados por essa interação, como propõe esse trabalho. 


\section{O Sistema Hyperties}

\subsection{Consideraçōes Iniciais}

O sistema de hipertexto Hyperties permite que se criem bases de dados constituídas de "artigos" ligados uns aos outros. Os artigos podem conter texto, figura, audio e vídeo. Um leitor pode entrar em qualquer ponto da base e, então, ver o artigo e movimentar-se (navegar) para outro que estiver relacionado a ele.

Um artigo (fig. 3.1), no Hyperties de acordo com [Co91], será apresentado através de seu conteúdo (content), que pode compor-se, por exemplo, de uma ilustração e de um texto, e juntamente com o artigo outras informaçōes serão apresentadas: o número de páginas que compõe o artigo; e, ligaçōes tipo botôes que permitem o acesso à próxima página do texto ou à anterior, ao módulo de ajuda, ao índice de artigos e, ainda, ao módulo de busca. No texto ou na ilustração do artigo pode-se encontrar, ainda, sinais que indicam uma ligação a outro artigo; no caso de 
texto, as palavras ou frases que indicam ligação estão em destaque em relação ao resto do texto.

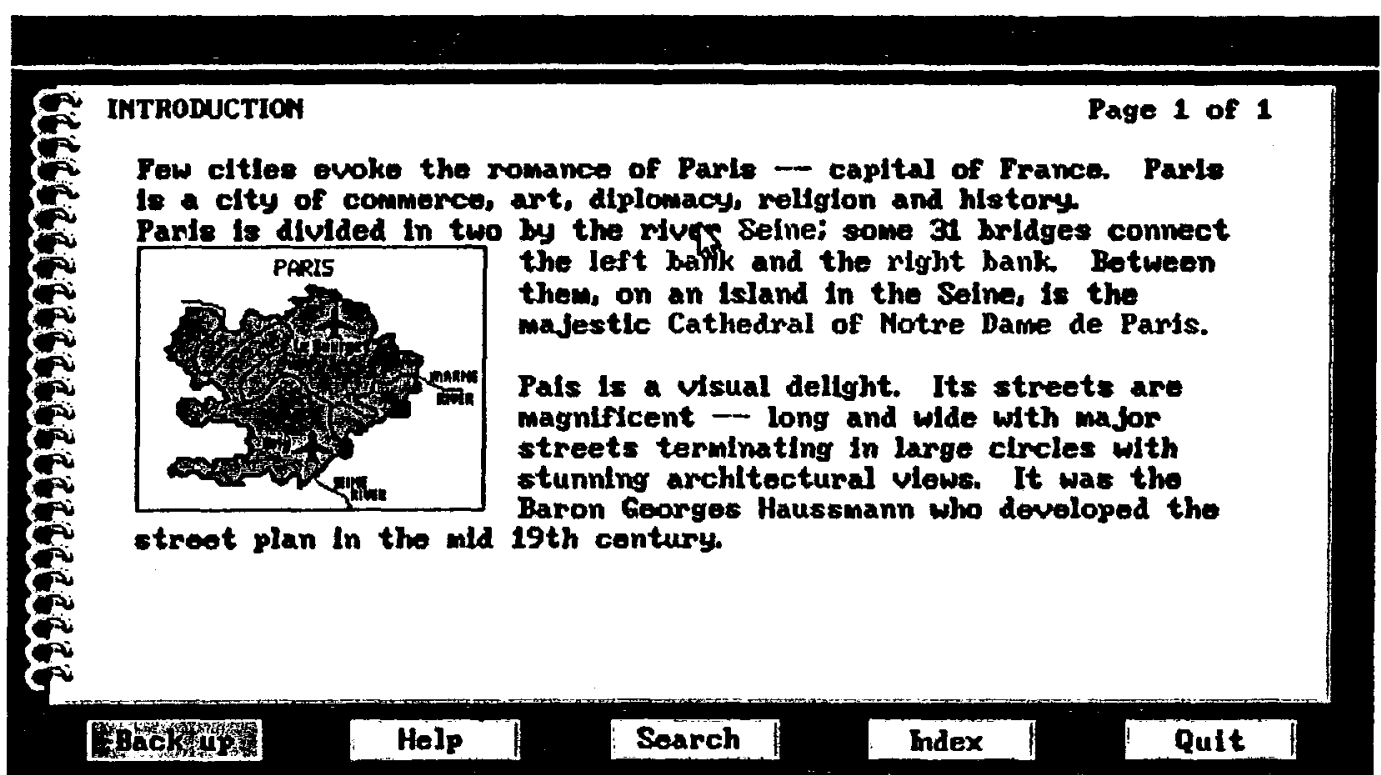

Fig 3.1 - Apresentação de um artigo no Hyperties

O sistema Hyperties constitui-se de uma série de programas que permitem criar, manipular, ler e distribuir as base de dados hipertexto. Os programas mais importantes são: BROWSER, que permite ler a base e deve ser distribuído juntamente com a base para o usuário; AUTHOR, que permite criar e manter a base; IMPORT que permite trazer um texto externo, editado por um processador de texto, para a base (isso é especialmente útil na criação de bases através de documentos já existentes); EXPORT, que permite converter a base para um arquivo texto; INDEX, que permite criar um índice para buscas por palavras ou frases; e, ainda, REPORT, que imprime relatórios sobre o conteúdo da base apoiando o trabalho de autoria.

A versão original do sistema Hyperties foi o sistema TIES, The Interactive Encyclopedia System, desenvolvido na Universidade de Maryland sob a supervisão 
do professor Ben Schneiderman, diretor do Human/Computer Interaction Laboratory.

Desde o início do projeto importantes decisões foram tomadas, entre elas:

- usar um modelo de enciclopédia constituído de artigos e referências, ao invés de usar um modelo tipo pilha de cartōes como, por exemplo, o sistema Hypercard, que não permite textos maiores que uma tela de computador;

- marcar o texto que será ligação com caracteres especiais, facilitando o trabalho do autor;

- incluir a criação automática de um índice de todos os artigos, que poderá ser referenciado pelo leitor;

- incluir um índice para busca por palavras ou frases do texto, possibilitando que o leitor localize informações às quais não se pode ter acesso através das ligações do hipertexto;

- incluir um mecanismo que permita ao leitor ver o caminho já percorrido;

- criar uma interface extremamente fácil de ser usada tanto pelo autor como pelo leitor.

Todas essas decisões estão na versão atual do Hyperties, que roda em microcomputadores compatíveis com IBM-XT/AT e pode apresentar-se numa versão padrão (Hyperties 3.0 Standard Edition), profissional (Hyperties 3.0 Professional Version) e, ainda, numa versão que utiliza a tecnologia DVI (Digital Video Interactive) da Intel (Hyperties 3.0 for DVI Technology).

A versão padrão é extremamente fácil de ser aprendida e usada. Ela traz um conjunto de vários estilos visuais, isto é, o autor escolhe um dos estilos que servirá para a apresentação dos textos e que será visto pelo leitor. $O$ autor não pode mudar o estilo escolhido, ou melhor, alterar cor e tamanho da janela, nome de botóes, etc., isso é inerente ao estilo escolhido. Já as outras versões oferecem maior poder e 
flexibilidade. $\mathrm{O}$ autor tem acesso a todas as características visuais da tela, além de poder usar estilos padrões e recursos de multimedia.

\subsection{Características Gerais e Terminologia}

Como já dito anteriormente, as bases no sistema de hipertexto Hyperties são constituídas de documentos, chamados artigos, e relacionados entre si através de ligaçōes.

Um artigo pode constituir-se de quatro partes:

- cabeçalho (header): título a ser exibido no topo de cada página que compõe o artigo;

- conteúdo (content): texto, ilustração, audio e vídeo que compõe o documento;

- descrição curta (short description): um breve texto que pode ser visto antes de se ir ao artigo;

- instrução de entrada (entry script): instrução na linguagem Hyperties.

O conteúdo é geralmente a parte mais importante de um artigo. Pode-se usar comandos de formatação para controlar e melhorar a aparência do texto como, por exemplo, fontes diferentes de letras, caracteres em negrito, tabulaçōes, etc.

A descrição curta é um trecho de texto que introduz o artigo. Quando a ligação para o artigo é ativada, a descrição é exibida inicialmente e, então, o leitor pode decidir-se por ler o artigo todo ou remover a janela da descrição e continuar no mesmo artigo. Os artigos podem conter somente a descrição, nesse caso, ela funcionará como um item de glossário ou nota de rodapé.

A instrução de entrada consiste de instruçōes na linguagem Hyperties e geralmente é usada por autores experientes. Como o nome indica, as instruções são executadas na entrada para o artigo e podem realizar operaçōes como: 
- testar variáveis e, então, exibir ou não determinado parágrafo;

- direcionar alguma informação para o disco;

- exibir um segmento de vídeo.

A ligação é o bloco básico de construção de uma base de dados hipertexto. Ela é a conexão entre os artigos. No Hyperties há três tipos de ligações:

- ligação textual (text link): palavras ou frases que indicam a ligação para outro artigo;

- ligação gráfica (graphic link): partes da ilustração que quando selecionadas causam a ocorrência de uma açāo especificada pelo autor;

- botões (buttons): texto ou ilustração que aparece na tela quando necessário.

As ligações textuais ou gráficas são criadas no módulo de autoria colocando numa palavra, frase ou numa parte da ilustraçāo marcas de ligação e devem ser resolvidas, isto é, deve-se indicar qual o artigo associado a essa ligação. O Hyperties, no módulo de navegação, destaca automaticamente o texto ou parte da ilustração marcada como ligação e o leitor pode usar o teclado, o mouse ou a tela, se for sensível a toque, para selecionar a ligação a seguir.

Os botōes são um tipo especial de ligação. Eles ajudam o leitor a se mover, por exemplo, para a próxima página de texto ou para a anterior ou, ainda, para o último artigo lido. Eles não são parte do artigo, mas integram o estilo visual escolhido para a apresentação. Com a versão profissional do Hyperties esses botões podem ser alterados.

\subsection{O Módulo de Autoria}

O módulo de autoria do sistema Hyperties permite, através de uma interface muito fácil de ser aprendida e usada, a criação ou seleção da base de dados hipertexto a ser manipulada, a atualização dessa base com a inclusão, modificação 
ou eliminação de artigos e suas respectivas ligações e o acesso ao módulo de navegação para que o autor possa verificar o que o leitor terá.

A criação da base de dados hipertexto implica na identificação da base, que é feita por dois nomes: um longo, que será apresentado ao usuário no momento em que ele acessar a base; e um curto, que servirá de nome para os arquivos que dizem respeito a essa base. Além dos nomes, na criação, o autor deverá selecionar o estilo visual para apresentação da base ao leitor. Ao selecionar uma base, o autor deverá simplesmente optar por alguma já existente.

Tendo criado ou selecionado alguma base, o autor poderá incluir um novo artigo. Para tal, inicialmente ele deverá entrar com um nome para o artigo que aparecerá num índice para o leitor e, então, ele poderá entrar com o cabeçalho, o conteúdo, a descrição curta e as instruçōes de entrada. Imediatamente após a entrada do conteúdo, se houver palavras ou frases marcadas como ligação para outro artigo, o autor deverá indicar os artigos associados a cada ligação.

O módulo de autoria permite, ainda, que as partes que compōem o artigo sejam preparadas em qualquer processador de texto e, então, importadas para montar $\mathrm{o}$ artigo. É importante observar que essa possibilidade exige que cada parte seja editada em arquivos texto diferentes e importados um a um.

Outra possibilidade para a criação da base é o uso de um programa utilitário IMPORT. Esse programa pode converter documentos já existentes para uma base de dados hipertexto. De uma única vez, ele pode trazer toda informação para a bașe e resolver todas as ligações.

A informação a ser importada para a base de dados hipertexto precisa estar em arquivos texto e conter comandos específicos que indiquem as partes dos artigos e as ligaçōes. As ligações são feitas automaticamente se todas se referenciarem a artigos contidos no mesmo arquivo texto. Entretanto, se houver vários arquivos a serem importados com referências entre eles, esse programa não será capaz de 
resolver essas ligaçōes, isto é, o programa não resolve ligações para artigos já existentes na base.

O módulo de autoria permite, ainda, que se exporte a base para arquivos texto gerando, assim, um arquivo que pode ser importado novamente para $o$ Hyperties com o programa IMPORT já citado.

Há a possibilidade de impressão de relatórios para apoiar o trabalho de autoria. Tais relatórios podem incluir a descrição de todas as partes dos artigos e as suas ligaçōes ou, então, uma lista dos artigos com indicação de quais partes o compõem. Esses relatórios podem ter um critério de seleção para indicar quais artigos devem ser relatados.

\subsection{O Módulo de Navegação}

A navegação numa base de dados, no sistema Hyperties, é feita através do BROWSER. Esse programa, a partir de uma tela de abertura, que pode ser incluida opcionalmente durante a autoria, oferece opçōes de ajuda, de informaçōes sobre a base de dados e de leitura da base de dados. A escolha dessas opções ou de outras que serão apresentadas em outras telas pode ser feita usando as teclas de movimentação de cursor no teclado, o mouse ou uma tela sensivel ao toque. Há a possibilidade de se escolher qualquer outro artigo para que seja exibido inicialmente.

Uma vez dentro da base de dados, o módulo de navegação exibe os textos e ilustraçōes de um artigo, o número de páginas que contém o artigo e qual página está sendo exibida, além de oferecer opçōes que permitem mudança de página, retorno, ajuda, busca por palavras ou expressōes, acesso ao índice e término do programa. 
No texto ou ilustração, as palavras ou frases e partes da ilustração que representam ligações a outros artigos aparecem destacadas. $O$ leitor pode acionar qualquer opção ou ligação e, então, navegar pela base.

A opção de retorno permite que o leitor retorne ao artigo ou opção anterior a que estava antes da situação atual. Se continuar a optar pelo retorno, o leitor poderá ver todos os artigos ou opções pelas quais passou até atingir o artigo inicial.

A opção pelo índice leva a uma tela que exibe uma lista alfabética de todos os artigos da base. Todos os nomes da lista são ligaçôes que levam ao artigo. Podese, então, selecionar o artigo que se deseja ler a partir desta opção. Entretanto, se a base contar com um número muito grande de artigos, a operação de procura por um nome por muitas páginas pode tornar-se cansativa. A opção TITLE SEARCH permite que se entre com o nome do artigo ou somente com as letras iniciais e, então, a busca é feita automaticamente.

A tela de índice também apresenta a opção HISTORY que exibe uma lista de todos os artigos que se leu, do último para o primeiro. Essa opção é uma maneira de ajudar o leitor a se orientar, principalmente se ele já seguiu por muitas ligaçōes e também é uma maneira do leitor saber como ele chegou ao ponto em que está.

Outra opção que merece destaque no módulo de navegação é a SEARCH que permite buscas através de palavras e expressões. Ao se entrar com uma palavra para ser encontrada, o módulo exibe todos os artigos que contém a palavra e o número de vezes que ela acorre em cada um, a partir daí pode-se acessar o artigo desejado dessa própria tela, já que cada nome de artigo é uma ligação para ele próprio. Na busca, pode-se, ainda, usar combinações de palavras através de operadores booleanos AND e OR, além de parênteses, no caso de expressōes mais complexas. 


\subsection{Considerações Finais}

Dentre todas as características apresentadas pelo sistema de hipertexto Hyperties, a que se destaca para o desenvolvimento deste trabalho é a possibilidade da importação de documentos já existentes para uma base de dados hipertexto, embora não seja possível a atualização da base com a construção automática de ligações, como já foi discutido anteriormente. Essa característica também foi explorada em [Fu89] com o estudo de quatro casos de criação de bases de dados hipertexto a partir de documentos já existentes.

Outra característica decisiva para a escolha desse software é a de rodar em microcomputadores compatíveis com IBM-XT/AT, já que a maioria dos sistemas de hipertexto desenvolvidos trabalha em ambiente Unix e ambiente McIntosh, ainda não muito difundidos em nosso meio. 


\section{Um Sistema de Hipertexto para Apoio a Reuniões Formais}

\subsection{Considerações Iniciais}

Neste capítulo, descreve-se um domínio de aplicação - reuniōes formais - que pode ser apoiado por sistemas de hipertexto e tem a característica de necessitar, para uso amigável, de autoria automática, pois o banco de dados cresce regularmente, exigindo que seja estabelecido um grande número de ligações com trechos de documentos já armazenados há bastante tempo, o que exigiria um trabalho árduo do usuário. Descreve-se, ainda, o desenvolvimento e implementação de um sistema de apoio para a autoria.

Reuniões formais são caracterizadas por emissão de convocação previamente à reunião e confecção de ata, isto é, relato por escrito das decisões tomadas durante a reunião. Elas têm o objetivo de deliberar sobre diversos assuntos 
de um determinado escritório, por exemplo, quem passará a chefiar determinado setor ou qual projeto deverá ser levado adiante ou não.

Pelas características apresentadas, os sistemas de hipertexto podem vir a apoiar as reuniões formais, substituindo o processador de texto tradicional por um sistema que, a partir da entrada da convocação e ata da reuniāo, permite que se faça, automaticamente, as associações apropriadas com as atas anteriores e facilitando posteriormente, através de mecanismos de acesso de navegação ou palavras-chaves, a recuperação de informações.

Para exemplificar esta aplicação dos sistemas de hipertexto, considerar-se-á o caso das reuniōes de Congregação que acontecem em algumas instituições da USP, especificamente as da Faculdade de Medicina de Ribeirão Preto.

A elaboração da convocação e da ata deverá ser feita pelo usuário que trabalhará interativamente com o sistema. Isto é, o sistema deverá exibir telas de opções com os diversos tipos de assuntos que competem à Congregação. $O$ usuário, ao fazer uma escolha, poderá editar o texto sobre o assunto a partir de um editor de texto, também disponível. Ao final da inclusão, o sistema deverá ser capaz de imprimir o texto integral da convocação e da ata.

O sistema deverá, também, a partir do texto da ata digitado pelo usuário, fazer as ligações convenientes automaticamente com as atas anteriormente digitadas. Essas ligações não incluem somente o texto em si, que trata de um assunto específico discutido pela Congregação, mas também, os objetos tratados pelo assunto. Por exemplo, considerem-se as inscriçōes de candidatos a um concurso qualquer que compete à Congregação avaliar. $\mathrm{O}$ assunto inscrição deve ser ligado ao último assunto inscrição em concurso ocorrido anteriormente, e cada nome que compõe a lista de candidatos deve ser ligado à última ocorrência daquele nome em qualquer outro assunto tratado anteriormente. 
Uma consulta, nesse sistema, se caracterizará pela navegação nessas ligaçōes ou, ainda, poder-se-á permitir uma busca por palavras chaves.

Este capítulo apresenta uma descrição de como acontecem atualmente as reuniōes de Congregação da FMRP-USP, um método para especificação de sistemas de armazenamento e recuperação de documentos, os aspectos selecionados da especificação, a aplicação do método para a aplicação considerada, a arquitetura geral do sistema proposto, a implementação do protótipo em Hyperties e as considerações finais sobre o trabalho.

\subsection{Descrição de Reuniões de Congregação da Faculdade de Medicina de Ribeirão Preto}

A Congregação da Faculdade de Medicina de Ribeirão Preto é um orgão da sua administração, composta pelo: diretor da unidade, presidentes das comissōes de graduação e pós-graduação, representantes dos professores titulares, associados, doutores, assistentes e auxiliares de ensino, representante dos ex-alunos, representante dos técnicos especializados, operacionais e administrativos e representantes do corpo discente de graduação e de pós-graduação. Ela se reune ordinariamente seguindo um calendário determinado pelo diretor da unidade ou, então, extraordinariamente, quando convocada pelo diretor ou por requerimento assinado, por no mínimo, um terço de seus membros titulares, ou, no impedimento oficial destes, pelos respectivos suplentes.

Cada sessão, ordinária ou não, é organizada em duas partes: a primeira Expediente - que compreende discussão e votação da ata da sessão anterior, comunicações do Presidente e palavra aos membros da Congregação; e a segunda Ordem do Dia. 
Havendo número legal de participantes na Congregação, o Presidente declara abertos os trabalhos e submete à discussão a ata da sessão anterior e, no caso de ter havido sessão extraordinária, a ata da reunião extraordinária também. Nesse momento os participantes, que já apreciaram o documento, solicitam ou não modificaçōes que devem ser aprovadas pelo colegiado e finalmente aprovam a referida ata. Seguem-se as comunicações do Presidente.

Nas comunicações, quando pertinente, o Presidente informa sobre resultados de eleições para representação junto à Congregação, programas de bolsas de estudo para docentes, relatório anual da unidade, etc.

Na palavra aos membros, os participantes esclarecem suas dúvidas sobre as comunicações, informam sobre assuntos que acharem de interesse do colegiado, fazem reclamações, enfim, têm a palavra para expor o que acharem conveniente.

Já na segunda parte da sessão - Ordem do Dia - os assuntos a serem abordados são mais técnicos e previstos na convocação da sessão de Congregação que cada membro recebe. Esses assuntos são analisados um a um e cada membro tem o direito de tecer comentários prós e contras acerca deles e, então, são submetidos à votação. É na Ordem do Dia em que são tomadas as decisões.

Os assuntos abordados na Ordem do Dia são, entre outros: convênios, concurso de ingresso na carreira docente, concurso para provimento efetivo de cargos de professor titular, concurso de livre-docência, abertura de concursos da carreira docente, renovação de contrato, composição de comissões julgadoras para mestrado e doutorado, expedição de segunda via de diploma, eleições para composição de comissões, auxílio-pesquisa e aprovação acerca de solicitação de colaboração de docente. Uma relaçāo de todos os assuntos de competência da Congregaçāo encontra-se no Apêndice A. 
Cada um desses assuntos tem características próprias e muitas vezes não acontece isoladamente como, por exemplo, aprovar inscrições dos candidatos a um concurso, sem antes aprovar a proposta de abertura de concurso.

Os assuntos a serem discutidos em sessões da Congregação são colocados em pauta anteriormente à sessão e, então, esta é enviada aos membros juntamente com a convocação.

Todas as discussões, colocações e decisões feitas durante a sessão da Congregação são relatadas em ata. A ata apresenta a mesma organização da sessão, isto é, primeira e segunda partes, além de incluir o dia, hora e os membros presentes e ausentes da sessão. Toda ata deve ser aprovada pelo Colegiado em sessão posterior e nessa oportunidade podem surgir modificações no texto.

Em todas as sessões de Congregações de instituições da USP encontra-se o mesmo procedimento, podendo haver diferenças nos termos usados para relatar as atas e nos assuntos de competência, pois alguns podem ser delegados ao Conselho Técnico Administrativo da instituição, se ele existir. Esses procedimentos são também similares, com ligeiras variações, a reuniōes formais em qualquer organização em geral.

\subsection{Um Método para Especificação de Sistemas de Armazenamento e Recuperação de Documentos}

Sirbu e outros, em [Si81], descrevem uma metodologia para a análise de "escritório", que fornece um conjunto de técnicas para facilitar e tornar efetivo o trabalho de automação que se deseja implantar. Essa metodologia opera em termos de funções. Uma função é um agregado de todas as atividades detalhadas que 
juntamente gerenciam e mantém alguns recursos relacionados aos objetivos da organização.

A função apresenta três estágios: início, gerência e fim. Em cada um desses estágios, procedimentos devem ser realizados e devem, para isso, manipular objetos, que compreendem as entidades abstratas de um escritório. No estágio inicial, os procedimentos criam documentos que durante a gerência serão passados por vários seções sendo autorizados, examinados, publicados, etc., até que sejam concluídos no estágio final.

Para melhor compreender considere a solicitação de financiamento em um banco. Inicialmente, faz-se o pedido preenchendo-se uma proposta e juntando-se diversos documentos ao pedido. Esse pedido desencadeia vários procedimentos como, por exemplo, verificação da validade dos documentos, comprovação de renda, autorização de parte da documentação e, assim por diante, até conclusão de autorização ou não, que caracteriza o estágio final, onde os documentos, no caso de autorização, iniciam uma nova função, cobrança, ou, no caso de não autorização, são arquivados ou devolvidos ao interessado.

Dessa maneira, esses estágios compõe o ciclo de vida de uma função: Dentro dessa perspectiva, propõe-se um método para especificação de sistemas de automação de escritório, dentro da sub-área dos sistemas para armazenamento e recuperação de documentos textuais, para auxiliar a conversão de documentos para o formato hipertexto, como, por exemplo, as atas de congregação, que apresentam um grande número de informação organizada em numerosos fragmentos relacionados entre si. Tal método dará apoio por computador a processos administrativos que, assim como as funçōes, apresentam um ciclo de vida.

O método compreende a criação de uma taxonomia do domínio da aplicação, a identificação de processos, a especificação dos processos e a identificação das ligações que poderão ser seguidas pelos usuários. 
O primeiro passo, criação de uma taxonomia do domínio da aplicação, compreende a definição de termos chaves que auxiliarão no entendimento e na solução do problema e no seu uso pelo usuário.

No segundo passo, identificação de processos, identificam-se as unidades discretas do problema, isto $\varepsilon$, os trechos atômicos de um documento que serão representados em nós num hipertexto, e seus relacionamentos, que serão representados pelas ligações num hipertexto. Um processo fica, então, associado a uma ou várias unidades discretas que se relacionam entre si e será representado por um diagrama de estado estendido (statechart, em [Ha88]). Nesse diagrama as unidades discretas são representadas por retângulos e seus relacionamentos pelas ligaçōes. Com isso estabelece-se o ciclo de vida dos processos, que pode ser entendido como a ordem em que cada unidade discreta ocorre no tempo.

Tendo sido identificados os processos e seus ciclos de vida, deve-se, no terceiro passo, especificar os processos em termos das características das unidades discretas, isto é, dos atributos que caracterizam os vários trechos de um documento. E, finalmente, no último passo, determinam-se quais ligaçōes serão relevantes aos usuários.

\subsection{Especificação do Sistema de Apoio a Reuniões Formais}

O sistema proposto deverá organizar o que for de competência da Congregação de forma a permitir a recuperação de um assunto através de vários aspectos, atores, etc, nele envolvidos como, por exemplo, permitir a recuperação de todas as propostas de realização de concursos na carreira docente, mas, também permitir a recuperação de todos os concursos prestados por determinado docente da unidade. 


\subsubsection{Criação de uma Taxonomia do Domínio de Aplicação}

Inicialmente são definidos alguns termos para o desenvolvimento do sistema. Uma reunião de Congregação será designada sessão. Em cada sessão discute-se e decide-se sobre os itens de competência da Congregação relacionados no Apêndice A e que serão chamados assunto, por exemplo: aprovação de proposta de abertura de concurso da carreira docente. E, finalmente, processo, que consiste de um ou vários assuntos que são discutidos em uma ou várias sessōes de Congregação. Por exemplo, considere-se o assunto, citado anteriormente, aprovaçāo de proposta de abertura de concurso da carreira docente. Em uma sessão é proposta a abertura de algum concurso pelo departamento, em outra são aprovados os candidatos e composta a comissão julgadora e, então, em outra, ainda, homologado o resultado final. A todo esse procedimento que pode englobar vários assuntos designa-se processo.

Um assunto é caracterizado pelos atributos: objeto, decisão e tipo. $\mathrm{O}$ objeto a que se refere um assunto pode ser, por exemplo, um docente, uma instituição, alunos, etc. Objeto é na realidade um meta-atributo, pois para representá-lo completamente armazena-se também os nomes de docente, de instituição e de alunos. A decisāo tomada pode ser, por exemplo, aprovação, cancelamento, etc. Um assunto pode, ainda, ter tipo, por exemplo, o assunto inscriçōes em concurso pode referir-se a concurso de efetivação, livre-docência ou titular.

Os participantes de uma sessão de Congregação são convocados através de uma pauta, que constitui-se de uma lista dos itens a serem discutidos na segunda parte - Ordem do Dia. Item de pauta é, então, uma instância de um determinado assunto de um processo e nele constam os nomes dos objetos envolvidos e um número que identifica o processo. 
O relato de uma sessão da Congregação será chamado de ata e deve organizar-se em: uma apresentação inicial com a identificação da ata e a relação dos membros presentes e ausentes; uma primeira parte - Expediente compreendendo a discussão e votação da ata anterior, comunicações do Senhor Presidente e palavra aos senhores membros; e uma segunda parte - Ordem do Dia, onde são discutidos e decididos os itens de competência da Congregação. Cada uma das subdivisões da primeira parte será considerada, também, um assunto. Abaixo apresenta-se, resumidamente, uma lista onde estão relacionados os termos definidos.

\footnotetext{
Sessão ................... Reunião da Congregaçāo

Item (Pauta) ........ Instância de um determinado assunto

Pauta .................... Lista de itens

Ata......................... Relato de sessão de Congregação

Assunto ................. Item de competência da Congregação

Objeto.................... Instituiçōes, alunos, etc. que são referidos no assunto

Tipo ....................... Variações de um assunto

Decisão.................. Decisão tomada acerca de um assunto, em uma sessão

Processo................ Procedimento que envolve um ou mais assuntos, distribuídos ao longo do tempo
} 


\subsubsection{Identificação do Ciclo de Vida dos Processos}

Tendo feito o levantamento dos termos chaves, é necessário, no momento, um levantamento de todos os assuntos de competência da Congregação em termos de suas fases e de documentos, pessoas e instituições envolvidos.

Para exemplificar, será apresentado inicialmente o processo comunicações do Presidente, consistindo apenas de um assunto, e concurso da carreira docente, consistindo de vários assuntos discutidos em várias sessōes. Os dois exemplos serão mostrados a partir de relatos de atas.

No trecho abaixo, tem-se o processo comunicações do Presidente.

Ata da 534a. Sessão Ordinária da Congregação da Faculdade de Medicina de Ribeirão Preto. No dia dezesseis de março de mil novecentos e noventa, às quatorze horas e trinta minutos,.... 1a. PARTE - EXPEDIENTE - ... 2. COMUNICAÇÕES DO SENHOR PRESIDENTE. O Senhor Presidente comunicou que: a) foram realizadas as seguintes eleições para representação junto à Congregação: 1) dos servidores não-docentes: Técnico Administrativo - eleitos: Representante Ronaldo Campos e Suplente Maria Alice Chaves. Para os representantes dos Técnicos Especializados e Operacionais não houve inscritos e 2) para Suplentes dos Professores Doutores e Assistentes foram eleitos, respectivamente, os Professores Marco Aurelio Rabelo e Antônio Alberto Figueiredo, ambos do Departamento de Ginecologia e Obstetrícia. A seguir o Senhor Presidente procedeu a leitura do documento que segue transcrito na íntegra: "Senhores Congregados, o Relatório da Unidade relativo ao ano de 1989 está em vias de conclusão..." 
No texto abaixo vê-se um trecho da ata onde é proposto o assunto solicitação de abertura de concurso.

\begin{abstract}
Ata da 533a. Sessão Extraordinária da Congregação da Faculdade de Medicina de Ribeirão Preto. No dia treze de dezembro de mil novecentos e oitenta e nove, às quatorze horas e trinta minutos,..., o Senhor Presidente declarou aberto os trabalhos passando à ORDEM DO DIA - 1....8. ABERTURA DE CONCURSO PARA PROVIMENTO EFETIVO DE 1 (UM) CARGO DE PROFESSOR TITULAR, Ref. MS-6, em RDIDP, junto ao departamento de Clínica Médica, em decorrência da aposentadoria do professor ... o Senhor Presidente submeteu à votação o item em tela, tendo o mesmo recebido aprovação unânime. (Proc FMRP 277/64).
\end{abstract}

Em seguida, têm-se os assuntos apreciação de inscrições e composição de banca examinadora e os candidatos e examinadores como seus objetos respectivamente.

Ata da 535a. Sessão Ordinária da Congregação da Faculdade de Medicina de Ribeirão Preto. No dia dezesseis de março de mil novecentos e noventa, às quatorze horas e trinta minutos, ... , o Senhor Presidente declarou aberto os trabalhos passando à ORDEM DO DIA - 1 ... 10. CONCURSO PARA PROVIMENTO EFETIVO DE 1 (UM) CARGO DE PROFESSOR TITULAR, Ref. MS-6, em RDIDP, junto ao departamento de Clínica Médica. a) aceitação das inscriçōes dos candidatos - Profs. Drs. PAULO SILVA OLIVEIRA e ROBERTO ANTONIO COSTA; b) indicação da comissão julgadora e c) designação de seu Presidente ... o Senhor Presidente disse que conforme os itens anteriores a votação seria secreta. Determinou a 
seguir a distribuição das cédulas especialmente preparadas. A apuração dos 51 votos foi feita pelos Professores Edison Amaral e Jose Oliveira. Obteve-se: Professores: PAULO SILVA OLIVEIRA, 50 votos favoráveis e 1 em branco, ROBERTO ANTONIO COSTA, 49 favoráveis e 2 contrários. O resultado significou a aceitação pelo Colegiado de todas as inscrições. Em sequência discutiu-se o item b indicação da Comissão Julgadora - ... o Senhor Presidente ... informou que submeteria a votos a sugestão de nomes para a Comissão Julgadora feita pela Comissão de Corpo Docente. A aprovação foi unânime, tendo a banca ficado assim constituída: Membros Efetivos: Profs. Drs. José de Souza Ferreira, Antonio Barros Silveira, Eduardo Figueira Filho, Flávio Morais e Ricardo Souto. Membros Suplentes: Profs. Drs. Luís Salgado e José Luís Ramos. Por proposta do Professor João de Oliveira, foi indicado o Professor José de Souza Ferreira para Presidente da referida Comissão. (Procs.USP. 89.1.1200.17.8, 89.1.1223.17.8).

E, finalmente, tem-se abaixo um trecho da ata com o assunto homologaçāo de resultado de concurso, completando-se todo o processo.

Ata da 537a. Sessão Extraordinária da Congregação da Faculdade de Medicina de Ribeirão Preto. No dia vinte de abril de mil novecentos e noventa, às quatorze horas e trinta minutos,..., o Senhor Presidente declarou aberto os trabalhos passando à ORDEM DO DIA - 1 ....3. CONCURSO PARA PROVIMENTO EFETIVO DE 1 (UM) CARGO DE PROFESSOR TITULAR, Ref. MS-6, em RDIDP, junto ao departamento de Clínica Médica. Candidatos: Profs. Drs. PAULO SILVA OLIVEIRA e ROBERTO ANTONIO COSTA. 
Homologação do Relatório Final Elaborado pela Comissão Julgadora. Parecer da Comissão de Corpo Docente. Como de praxe o Senhor Presidente informou que às fls. 6 a 10 do anexo da Ordem do Dia, constava a documentação pertinente ao ítem, colocando o assunto em discussão. ... o Senhor Presidente colocou o assunto em votação, tendo sido o mesmo aprovado por unanimidade. (Procs.USP. 89.1.1200.17.8, 89.1.1223.17.8).

Um processo, como já dito, constitui-se de um ou mais assuntos que são discutidos em várias sessões da Congregação. Já que um dos objetivos desse sistema é promover a consulta/navegação, é necessário que os assuntos envolvidos num processo estejam ligados na base de dados hipertexto, possibilitanto ao usuário navegar por todo o processo espalhado ao longo de várias reuniões.

Pretende-se que essas ligaçōes sejam feitas automaticamente, para isso, como os assuntos são informados ao sistema à medida em que ocorrem, necessita-se saber qual o último assunto discutido em sessão de Congregação que diz respeito a um determinado processo para se poder ligá-lo ao assunto corrente. Se se conhecer todos os assuntos que compōem um processo, isto é, seu ciclo de vida, as ligaçōes podem ser feitas automaticamente.

Para exemplificar, considerem-se os dois processos já citados e relatados anteriormente: comunicações do Presidente e concurso da carreira docente.

O processo comunicações do Presidente consiste no relato de vários assuntos, entretanto não são assuntos estruturados e previstos como os que ocorrem na segunda parte da sessão, na ordem do dia, dessa forma, considera-se que esse processo compõe-se de um único assunto de mesmo nome do processo.

Já o processo concurso da carreira docente, seguindo o caminho sem exceçōes, constitui-se de uma solicitação de abertura de concurso, apreciação de inscriçōes de 
candidatos, composição de banca examinadora e homologação do resultado do concurso.

Inicialmente, um departamento solicita a abertura de um concurso à Congregação. Diante da solicitação, pode-se decidir pela aprovação ou não, ou, ainda, por uma modificação nos requisitos da abertura. Tal modificação deve ser feita pelo departamento que novamente submeterá o assunto a discussão em outra sessão.

Com a aprovação da abertura, em uma próxima sessão de Congregação, serão discutidos os assuntos: apreciação de inscriçōes e composição de banca examinadora. Cada candidato inscrito é aprovado ou nâo para participar do concurso. $\mathrm{Na}$ composição da banca examinadora, propõem-se nomes de examinadores que sendo convidados podem aceitar ou não o convite; então pode-se conseguir formar a banca ou não. Se a banca não for formada, novamente, em outra sessão de Congregação faz-se a recomposição da banca e assim por diante, até se conseguir formá-la. Se nesse período se esgotar o prazo para a composiçāo da banca, o concurso é suspenso terminando o processo.

E, finalmente, numa última etapa do processo, é homologado o resultado do concurso. Ainda, pode-se decidir por uma reformulação do resultado e então o assunto voltará a ser discutido em outra sessão, ou um candidato pode entrar com um recurso para que o resultado seja previsto.

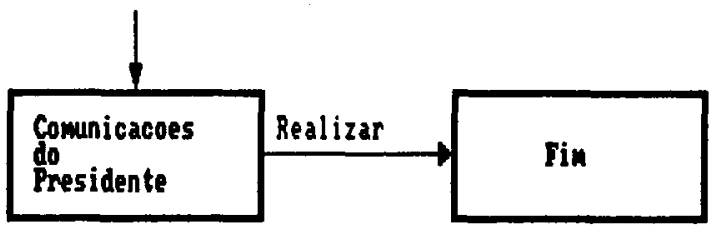

Fig. 4.1 - Diagrama de Estado: Comunicações do Presidente 


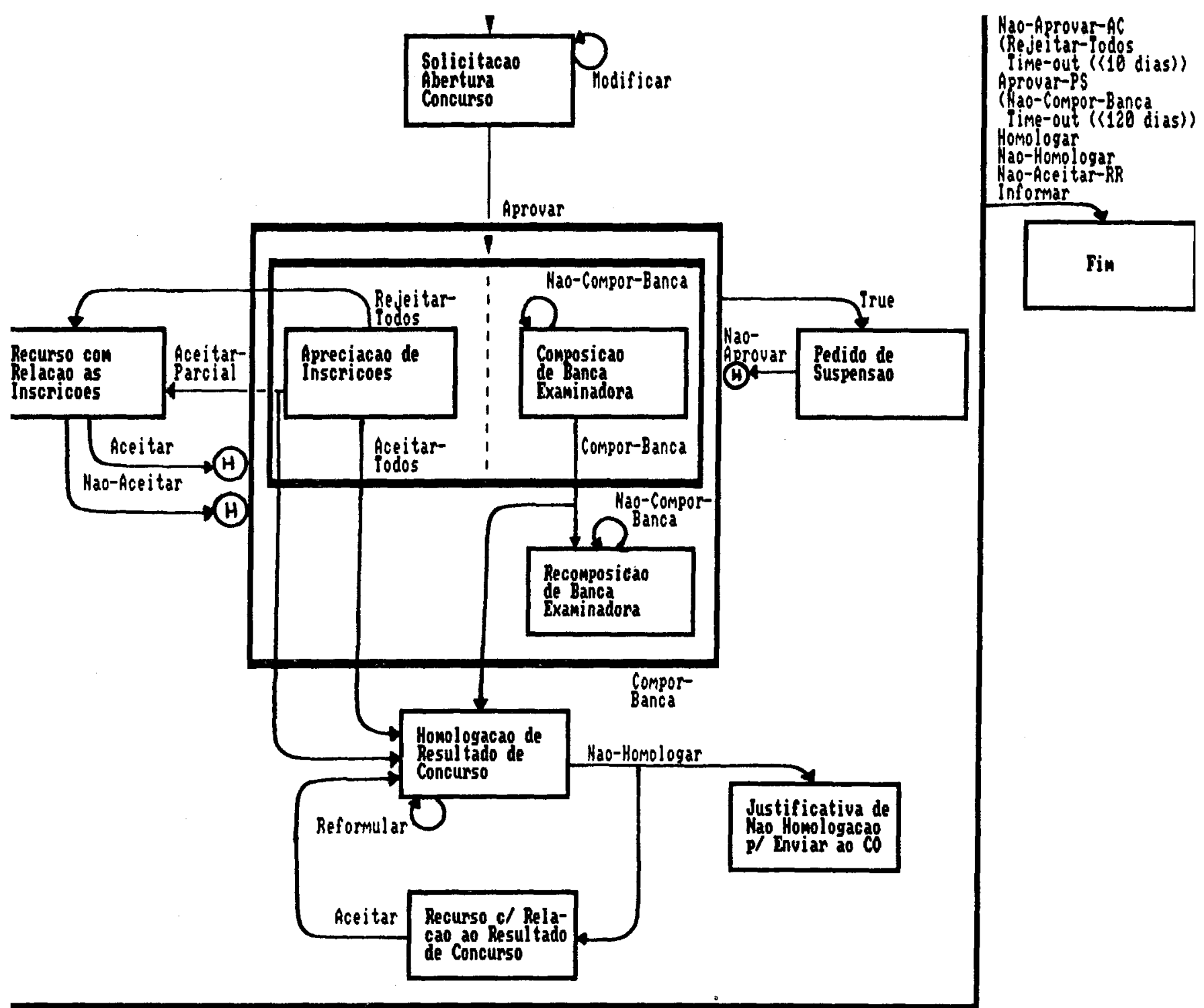

Fig. 4.2 - Diagrama de estado: Concurso da Carreira Docente

O ciclo de vida dos processos pode ser representado por diagramas de estado, facilitando a definição dos nós e das ligações. Nas figuras 4.1 e 4.2 têm-se os diagramas de estado para os processos comunicações do Presidente e concurso da carreira docente respectivamente. Os estado representam cada assunto relativo ao processo. Na figura 4.2, o estado dividido ao meio pela linha tracejada indica a necessidade de que os dois assuntos no qual é decomposto sejam julgados em uma 
mesma reunião. As decisões tomadas com relação a um assunto habilitam as transiçōes que podem, então, ser executadas quando um novo assunto ocorre.

Além disso, permite-se que o diagrama de estado seja não determinístico, como ocorre, por exemplo, com a transição rotulada pela decisão Nāo-Homologar na figura 4.2. $O$ significado é o seguite: como a decisão ocorre antes que o assunto seguinte apareça na pauta, pode-se checar se o sequenciamento de assuntos está correto. No exemplo da figura 4.2 tanto o assunto Recurso com Relação ao Resultado de Concurso como o assunto Justificativa de Não Homologação para Enviar ao CO podem aparecer após a decisão de não homologação de um resultado de concurso, mas apenas um deles.

$\mathrm{O}$ símbolo $\mathrm{H}$ associado às transições tem o mesmo significado do diagrama de estado convencional: indica o retorno ao estado atômico em que a execução se encontrava quando o superestado foi visitado pela última vez.

\subsubsection{Especificação dos Processos}

Neste passo, especificam-se os processos em termos dos assuntos e suas características. Essa especificação é auxiliada pelos diagramas de estado das figuras 4.1 e 4.2 .

Pode-se, com base no diagrama da figura 4.1, concluir:

Processo

Comunicações do Presidente

Assunto

Comunicações do Presidente

Objeto : Presidente

Decisão: Realizar

Tipo :- 
Com base no diagrama da figura 4.2, conclui-se que:

\section{Processo}

Concurso da Carreira Docente

Assunto

Solicitação de Abertura de Concurso

Objeto : Departamento

Decisão: Modificar

Aprovar-AC

Não-Aprovar-AC

Tipo : Professor Titular

Apreciação de Inscrições

Objeto : Candidatos

Decisão: Aceitar-Todos

Aceitar-Parcial

Rejeitar-Todos

Tipo : Professor Titular

Composição de Banca Examinadora

Objeto : Examinadores

Decisão: Compor-Banca

Não-Compor-Banca

Tipo : Professor Titular 
Homologação de Resultado de Concurso

Objeto : Candidatos

Decisão: Homologar

Não-Homologar

Reformular

Tipo : Professor Titular

Ainda pelo diagrama observa-se que, durante o processo, pode haver um pedido de suspensão:

Assunto

Pedido de Suspensão

Objeto : Concurso

Decisão: Aprovar-PS

Não-Aprovar-PS

Tipo : Professor Titular

ou, ainda, recomposição de banca examinadora:

Assunto

Recomposição de Banca Examinadora

Objeto : Examinadores

Decisão: Compor-Banca

Não-Compor-Banca

Tipo : Professor Titular

ou, ainda, recurso com relação às inscrições:

Assunto

Recurso com Relação às Incriçōes 
Objeto : Candidatos

Decisão: Aceitar-RI

Não-aceitar-RI

Tipo : Professor Titular

com relação ao resultado do concurso:

Assunto

Recurso com Relação ao Resultado do Concurso

Objeto : Candidatos

Decisão: Aceitar-RR

Não-aceitar-RR

Tipo : Professor Titular

e, finalmente, justificativa de não homologaçāo ao Conselho Universitário:

Assunto

Justificativa de Não Homologação ao CO

Objeto : Candidatos

Decisão: Informar

Tipo : Professor Titular

\subsubsection{Identificação das Ligações}

Cada assunto da sessão de Congregação, no sistema, é um nó que consiste de um título, um número de sessão e uma descrição. As ligações devem ser capazes de fornecer, genericamente: a) o processo em que está envolvido o assunto; b) os mesmos assuntos tratados anteriormente a esse em questão; c) em quais assuntos um determinado objeto está envolvido; e d) os assuntos de um mesmo tipo. 


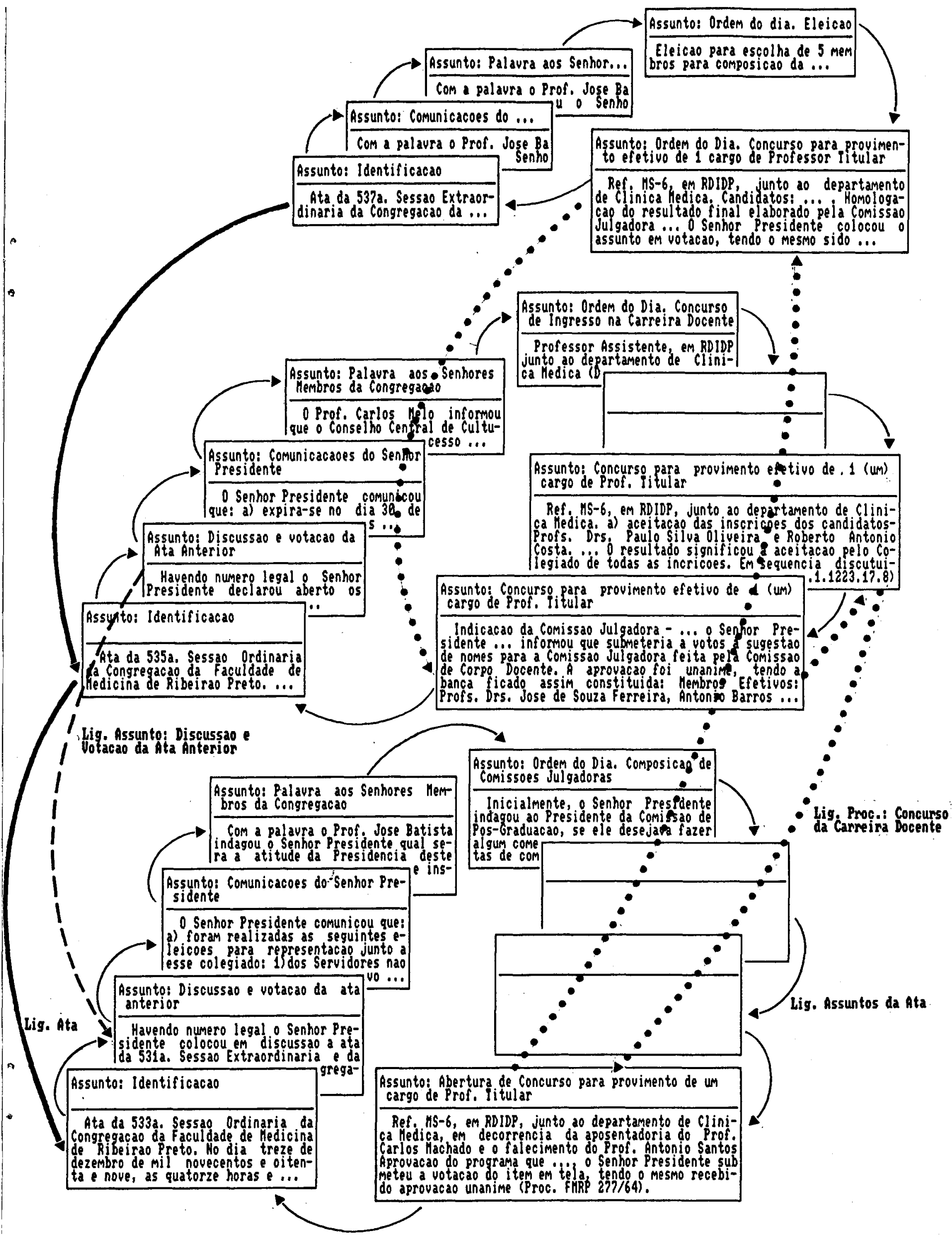

Fig. 4.3 - Base de Dados Hipertexto com os Detalhes dos Exemplos 
Nos exemplos considerados, as ligações pode ser: de todas as comunicações do presidente, solicitações de abertura de concursos, apreciações de inscrições, composições de bancas examinadoras e homologações de resultados de concursos. Ainda, ligaçōes entre os assuntos de um mesmo processo para se delineá-lo e ligaçōes dos docentes à última ocorrência deles com relação à apreciação de inscriçōes ou homologação de resultado de concurso.

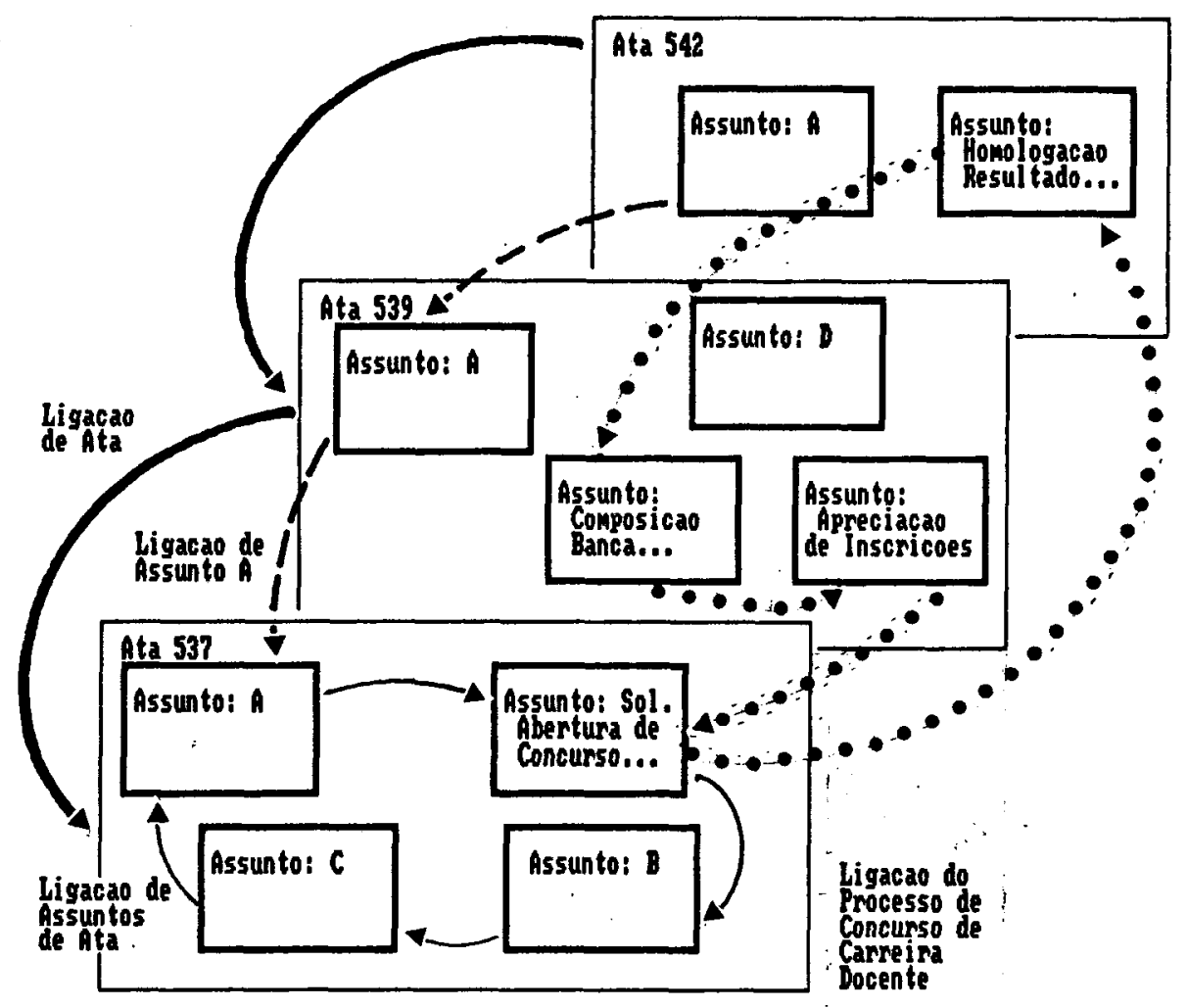

Fig. 4.4 - Representação das Ligações na Base de Dados

A base de dados hipertexto para os exemplos deve estar organizada como se vê na figura 4.3, que mostra um esquema da base de dados com os detalhes dos exemplos. Já a figura 4.4 mostra um esquema genérico e simplificado das ligações na base de dados, mostrando somente: a) a ligação entre os vários assuntos das atas organizados na ordem em que são discutidos na sessão; b) a ligação dos assuntos 
envolvidos no processo de concurso na carreira docente; e c) a ligação de um mesmo tipo de assunto, no caso, do assunto comunicaçōes do presidente.

\subsection{Arquitetura Geral do Sistema}

Com o objetivo de implementar o sistema especificado na seção anterior, elaborou-se um projeto constituído de quatro sub-sistemas principais, mostrados na figura 4.5: preparação, impressão de pauta/ata, conversão, e consulta/navegação. Esses sub-sistemas compõem outros dois sistemas: específico e hipertexto, que juntos formam o sistema de apoio a reuniōes.

O sub-sistema de preparação permite a entrada dos assuntos a serem discutidos na sessão da Congregação, através da seleção desses assuntos em telas de opções e de sua edição, determinando com isso os assuntos que constarão da pauta da reunião e posteriormente da ata. Permite que, após a reunião, a estrutura da ata, já determinada, seja completada com as discussões e decisões sobre os assuntos, e ainda gera a ata com marcadores no texto para a importação para o sistema de hipertexto Hyperties.

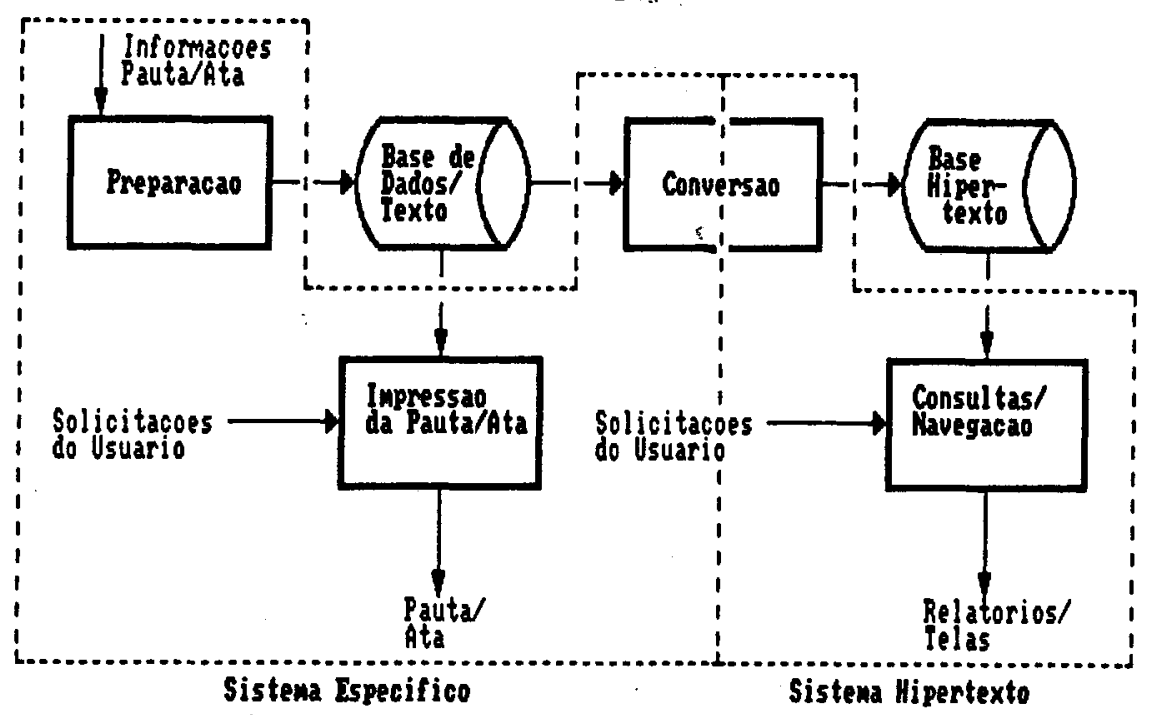

Fig. 4.5 - Sub-Sistemas Principais do Sistema 
A impressão da pauta e da ata em texto linear é feita pelo sub-sistema de impressão, que organiza as informações fornecidas pelo usuário de uma maneira pré-estabelecida.

O sub-sistema de conversão, a partir do arquivo da ata com os marcadores estabelecidos, faz as ligações. Para isso considera os assuntos, representados por nós, e as ligações que foram definidas.

O sub-sistema de consulta/navegação fornece possibilidades de se percorrer a base através das ligações estabelecidas e através de um índice formado pelos diversos assuntos ou por palavras.

\subsection{Implementação de um Protótipo em Hyperties}

Para implementação do sistema de apoio a reuniōes utilizou-se o sistema de hipertexto Hyperties e um sistema específico desenvolvido em linguagem Clipper 5.01, o qual congrega os sub-sistemas de preparação, de impressão da pauta e ata e parte do sub-sistema de conversão.

Nesse sistema específico, a preparação, tanto da pauta como da ata, é feita através de telas de opções de processos e assuntos e da edição das informaçōes complementares. Internamente, o sub-sistema de preparação trabalha com duas tabelas principais, uma que representa genericamente os ciclos de vida dos processos, isto é, os diagramas de estado, em termos dos assuntos que o compõem, seus atributos e sua ordem de ocorrência. E outra tabela em que são registradas as instâncias de cada processo ativo, desde o assunto que inicia o processo até o assunto que completa seu ciclo de vida quando, então, suas informações são retiradas da tabela. 
As informaçōes de um assunto discutido na reunião que o usuário fornece são, então, utilizadas para fazer avançar o estado do processo na tabela de instâncias, depois de se ter verificado a validade da informação pela tabela generica dos processos.

O sub-sistema de preparação, através da tabela de instâncias, determina qual o último assunto discutido que diz respeito ao processo em questão. Tal assunto, como já foi discutido em reunião anterior, deve constar da base de dados hipertexto e, então, determina-se a ligação do assunto corrente com o já discutido. Analogamente, determinam-se as ligações dos objetos e tipos do assunto corrente com os outros assuntos da base, além de se determinarem as ligações dos assuntos que compōem a ata.

As ligações que compõem a ata são representadas por marcadores no texto composto a partir das informações fornecidas pelo usuário e feitas automaticamente pelo sistema de hipertexto Hyperties na importação do texto para esse sistema. Entretanto, as ligações dos assuntos, objetos e decisões correntes com os assuntos, objetos e decisões que já estão na base não podem ser feitas automaticamente, já que o sistema Hyperties não oferece tal facilidade. Para essas ligações, o subsistema de conversão gera um relatório indicando as ligações que devem ser realizadas através do módulo de autoria do sistema Hyperties.

A conversão, então, das informações fornecidas pelo usuário para uma base de dados hipertexto é parcialmente automática, utilizando-se o módulo de importação do sistema Hyperties, e parcialmente manual, utilizando-se o módulo de autoria do sistema Hyperties e um relatório de apoio gerado pelo sistema de específico.

O sub-sistema de conversão, portanto, consiste a) no uso do sistema específico atraves: da geração do arquivo texto contendo a ata e os respectivos marcadores para as ligações e do relatório de apoio para as ligações com os 
assuntos que já estão na base de dados hipertexto; e, b) no uso do sistema Hyperties através: de seu módulo de importação para incorporar a nova ata na sua base e de seu módulo de autoria para permitir ao usuário fazer as ligações necessárias.

A consulta/navegação é realizada através do módulo de navegação do sistema Hyperties, que oferece facilidades para se percorrer a base através das ligações estabelecidas, através de um índice formado pelos diversos assuntos ou, ainda, através de busca por palavras ou expressões.

\subsection{Consideraçōes Finais}

Com base na bibliografia estudada e nas características do sistema proposto pode-se concluir que o trabalho atinge o objetivo pretendido de apoiar reuniōes usando hipertexto.

A elaboraçāo da pauta fornece a estrutura da ata que, quando completada pelo usuário com o que for discutido na sessão da Congregação, forma a base de dados hipertexto ligando-se às outras atas que já estão na base. Essas ligações possibilitam a navegaçāo por várias atas à procura de um assunto discutido ou de um determinado docente, por exemplo, auxiliando decisões a serem tomadas, estudos históricos da instituição, pareceres, etc, mas principalmente auxiliando o estabelecimento de um padrão de registro dos acontecimentos.

Deve-se observar que os recursos para a ligação de mesmos objetos e assuntos de um mesmo tipo não foram mostrados no exemplo, pois comportam-se de maneira análoga àquela que foi exemplificada.

O sistema, como visto, não foi desenvolvido para o uso pelos participantes da reuniāo concomitantemente à realização da mesma, pois não se pretendeu apoiar a 
comunicação entre eles, apesar disso ser importante. Entretanto, ele poderá ser estendido à medida em que surgir a necessidade e houver recursos para isso.

Pode-se considerar o sistema bastante específico, uma vez que está preparado para aceitar somente assuntos de competência de uma Congregação de uma instituição da USP. Porém, é importante observar que a base desenvolvida pode ser aplicada a outras organizações e seria relativamente fácil desenvolver um sistema que tivesse como entrada os assuntos de competência de um colegiado de outra organização e tudo o que se referissse a eles: tipos, decisōes e objetos. Esse sistema montaria, então, uma base de dados de especificações para ser acessada pelo sistema específico. 


\section{Uso e Avaliação do Protótipo Implementado}

\subsection{Considerações Iniciais}

Este capítulo pretende demonstrar o uso dos sub-sistemas de preparação, conversão e navegação descritos no capítulo anterior e para isso, como exemplo, considera a elaboração da pauta e, em seguida, da ata de uma sessão de Congregação com os itens: comunicações do Presidente; solicitaçāo de abertura de concurso pelo departamento de Clínica Médica; apreciação de inscrições para concurso do departamento de Fisiologia solicitado e aprovado em sessōes anteriores; e, composição de comissōes julgadoras propostas pela comissão de PósGraduação.

A seção Autoria apresenta os sub-sistemas preparação e conversão, que juntos incluem novas informações na base de dados de atas. A seção Navegação, sub-sistema implementado com o módulo de navegação do sistema de hipertexto Hyperties, mostra como percorrer a base através das ligações definidas, além de outros recursos oferecidos pelo Hyperties. 
Como resultado dessa análise, algumas deficiências das ferramentas utilizadas são apresentadas e também algumas sugestões de recursos a serem incorporados aos sistemas de hipertexto atuais. E, então, são apresentadas as considerações finais do capítulo.

\subsection{Autoria}

A autoria compreende a utilização de um sistema específico desenvolvido em linguagem Clipper 5.01 e, ainda, do módulo de importação e autoria do sistema de hipertexto Hyperties.

O sub-sistema, através de telas de opçōes e entrada de dados, reune as informações necessárias para serem exportadas para o sistema de hipertexto. Para melhor compreensão do procedimento de autoria, considere o exemplo já citado.

Inicialmente, através do sub-sistema de preparação, será necessário informar os assuntos a serem discutidos e compor a pauta. A figura 5.1 mostra a tela de entrada do sub-sistema onde o usuário deve informar o número da sessão a ser realizada e se é ordinaria ou não.

A seguir, na figura 5.2, tem-se um menu de opçōes onde o usuário poderá decidir sobre montar a pauta ou a ata. Obviamente, o sub-sistema não permite montar a ata se a respectiva pauta não tiver sido incluída.

A opção Pauta oferece um sub-menu de opções onde se pode informar sobre a primeira parte da sessão, expediente, ou a segunda, ordem do dia, ou, ainda, imprimir a pauta. A opção Ata também oferece um sub-menu com opções para se informar as discussōes do expediente e as discussões e decisōes da ordem do dia, além de oferecer possibilidade de impressão e geração das informações para serem importadas pelo Hyperties. As figuras 5.3 e 5.4 mostram, respectivamente, os submenus de Pauta e Ata. 
Sistema de Apoio a Reunioes da FMRP

Entre com o numero da Sessao: 533 Ordinaria/Extraordinaria (0/E)? 0

Fig. 5.1 - Informações sobre Número e Tipo da Sessão

Sistema de Apoio a Reunioes da FMRP

Sessao 0533

Pauta Ata Relatorios Fim

Fig. 5.2 - Menu de Opçōes Principais 
Pauta Ata Relatorios Fim

Expediente

Ordem do Dia

Impressao

Fig. 5.3 - Sub-menu da Opção Pauta

Sistema de Apoio a Reunioes da FMRP

Pauta Ata Relatorios Fim

Expediente

Ordem do Dia

Impressao

Saida Hties

Fig. 5.4 - Sub-menu da Opção Ata 
Ao se optar por Expediente na opção Pauta, outro sub-menu é exibido (fig. 5.5), permitindo escolher qual dos três itens comporá o expediente. Numa sessão ordinária, normalmente os três itens aparecem no expediente, já numa sessão extraordinária pode ser que nenhum dos três ocorra. Pelo menu, o usuário escolhe o que for mais conveniente. Na figura 5.6 tem-se uma tela supondo que tenha sido feita a escolha dos três itens pelo usuário. Entende-se que o usuário já informou as sessões anteriores que serão discutidas e votadas.

No sub-menu Pauta, ao se optar por Ordem do Dia apresenta-se um menu (fig. 5.7) com todas as deliberações da Congregação que já foram implementadas. Considerando o exemplo a ser apresentado, deve-se optar pelo processo Concurso da Carreira Docente que oferece outro menu com todos os assuntos que compōem esse processo (fig. 5.8) e, então, optar por Solicitação de Abertura de Concurso.

Sistema de Apoio a Reur
Pauta - Informe assunt
Discussao e Votacao
Comunicacoes
Palavra aos Membros

Fig. 5.5 - Sub-menu da Opção Expediente 
Pauta - Informe assuntos que serao discutidos na la. Parte - Expediente

Discussao e Votacao

Comunicacoes

Palavra aos Membros
Entre com o no. da ata da Sessao anterior a ser discutida e votada

No. (Ordinaria): 532

No. (Extraordinaria):

Pauta

1a. Parte - Expediente

2. Comunicacoes do Senhor Presidente

3. Palavra aos Senhores Membros da Congregacao

Fig. 5.6 - Tela com a Escolha das Três Opções

Sistema de Apoio a Reunioes da FMRP Sessao 0533

Pauta - Informe assuntos que serao discutidos na 2a. Parte - Ordem do Dia

Auxilio Pesquisa

Composicao de Comissoes Julgadoras pela CPG

Concurso da Carreira Docente

Convenio

Eleicao

Equivalencia de Diploma

Expedicao de 2a. Via de Diploma

Contratacao de Professor Colaborador

Revalidacao de Diploma

Solicitacao de Colaboracao de Professor

Nucleos de Apoio as Atividades-Fim

Recuperacao em Disciplinas dos Cursos de Grad

Programas de Concursos (Livre-Docencia)

Fig. 5.7 - Menu com as deliberaçōes da Congregação 
Pauta - Informe assuntos que serao discutidos na 2a. Parte - Ordem do Dia

Auxilio Pesquisa

Composicao de Comissoes Julgadoras pela CPG Concurso da Carreira Docente

Convenio

Eleicao

Equivalencia de Diploma

Expedicao de 2a. Via de Diploma

Contratacao de Professor Colaborador

Revalidacao de Diploma

Solicitacao de Colaboracao de Professor

Nucleos de Apoio as Atividades-Fim

Recuperacao em Disciplinas dos Cursos de Grad

Programas de Concursos (Livre-Docencia)
Solicitacao de Abertura de Concur Apreciäcao de Inscricoes Composicao de Banca Examinadora Homologacao de Resultado de Concu Pedido de Suspensao

Recomposicao de Banca Examinadora Recurso com Relacao as Inscricoes Recurso com Relacao ao Resultado Justificativa de Nao Homologacao Fim

Fig. 5.8 - Sub-Menu da Opção Concurso da Carreira Docente

Ao optar-se por Solicitaçāo de Abertura de Concurso, o sub-sistema verifica numa tabela que representa os ciclos de vida dos processos qual evento pode levar a um certo estado. Nesse caso, dois eventos geram uma solicitação de abertura de concurso (fig. 4.2), ou o início de uma nova instância do processo Concurso da Carreira Docente, ou uma decisão de modificação ocorrida em alguma sessão anterior, isto é, iniciou-se o processo com uma solicitação de abertura de concurso e a decisão da Congregação foi a de modificação em alguns aspectos do concurso, o que fez com que o conselho departamental revisse esses aspectos e novamente submetesse a solicitação à Congregação.

Diante disso e somente com a informação do usuário sobre o assunto Solicitação de Abertura de Concurso constar em ata, o sub-sistema exibe um menu 
de todos os assuntos Solicitação de Abertura de Concurso que já passaram em ata, com a decisão Modificar e que ainda não tiveram continuidade, isto é, é o último assunto a ser discutido daquela instância de processo. Para isso, o sub-sistema considera a tabela em que são registradas as instâncias de cada processo ativo. Esse menu exibe, ainda, a possibilidade desse assunto ser o início de uma nova instância do processo, com a opção Novo Assunto. A figura 5.9 mostra esse exemplo.

\begin{tabular}{l} 
Sistema de Apoio a Reunioes da FMRP \\
\hline Pauta - Informe assuntos que serao discutidos na 2a. Parte - Ordem do Dia \\
\hline 2-Concurso da Carreira Docente \\
Solicitacao de Abertura de Concurso \\
Verfique se assunto a ser colocado em pauta da' continuidade aos \\
que estao relacionados ou e' um assunto novo. \\
Concurso para um (1) cargo de Prof. Titular. Depto Farmacologia \\
Assunto Novo
\end{tabular}

Fig. 5.9 - Menu de Processos Iniciados e Novos

Nesse exemplo, considere o processo como sendo novo. Após feita a opção, o sub-sistema pede informações sobre descrição, objetos, tipo e texto a constar da pauta conforme pode-se observar pelas figuras 5.10 e 5.11 
Continuando o exemplo, o próximo assunto será a Apreciação de Inscriçōes. Novamente, ao se optar por esse assunto, o sub-sistema exibe todas as instâncias de processo ativo em que o último assunto tenha sido Solicitação de Abertura de Concurso e, ainda, uma opção permitindo o início de um novo processo que apesar de não ser válido, essa situação precisa ser considerada, já que inicia-se a base a partir de uma sessão qualquer de Congregação com vários processos em andamento. Para garantir que o usuário não está errando ao optar por um processo novo, o sub-sistema alerta-o sobre essa situação e pede confirmação, como ilustra a figura 5.12.

Para se incluir o assunto Composição de Banca Examinadora, o usuário e o sub-sistema passarão por etapas análogas às do assunto Apreciação de Inscrições. Ao final, o usuário poderá imprimir a pauta, conforme se vê na figura 5.13.

\begin{tabular}{l}
\hline Sistema de Apoio a Reunioes da FMRP \\
\hline Pauta - Informe assuntos que serao discutidos na 2a. Parte - Ordem do Dia \\
\hline 2-Concurso da Carreira Docente \\
Solicitacao de Abertura de Concurso
\end{tabular}

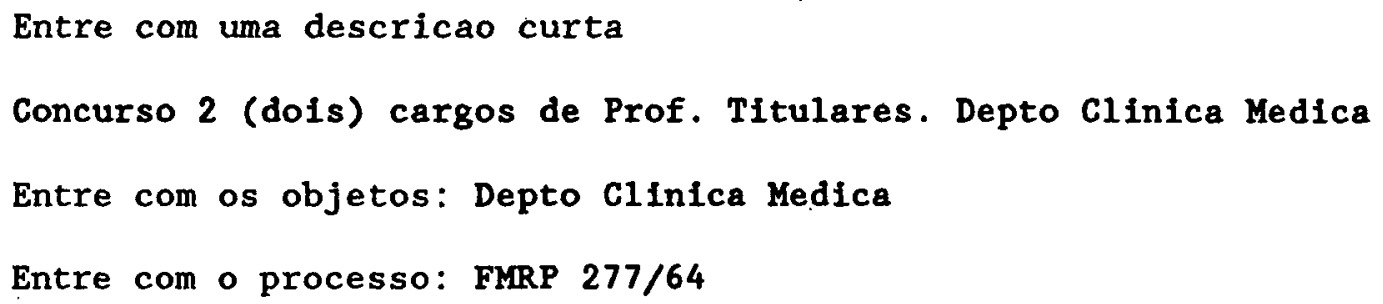

Fig. 5.10 - Entrada de Dados sobre Solicitação de Abertura de Concurso 
Pauta - Informe o texto que constara da pauta

Entre com o texto (tecle ESC para terminar):

toncurso para provimento efetivo de 2 (dois) cargos de Professor Titular, Ref. MS-6, em RDIDP, junto ao Departamento de Clinica. Solicitacao de Abertura de concurso. Parecer da Comissao de Corpo Docente. (Proc. FMRP 277/64).

Fig. 5.11 - Entrada do Texto sobre Solicitação de Abertura de Concurso

\begin{tabular}{l}
\hline Sistema de Apoio a Reunioes da FMRP \\
\hline Pauta - Informe assuntos que serao discutidos na 2a. Parte - Ordem do Dia \\
\hline $\begin{array}{l}\text { Erro!. O assunto da' continuidade a outro que nao existe. } \\
\text { Ainda assim deseja incluir? (S/N) s }\end{array}$
\end{tabular}

Fig. 5.12 - Alerta sobre Processo com Início Errado 
PAUTA

533a. Sessao Ordinaria da Congregacao

1a. PARTE - EXPEDIENTE

1. Discussao e votacao da Ata da Sessao: 532a. Ordinaria

2. Comunicacoes do Senhor Presidente

3. Palavra aos Senhores Membros da Congregacao

2a. PARTE - ORDEM DO DIA

1. Concurso da Carreira Docente Apreciacao de Inscricoes

Concurso para provimento efetivo de 1 (um) cargo de Professor Titular, Ref. MS-6, em RDIDP, junto ao Departamento de Fisiologia. Candidato: Profs. Dr. Helio Sanches e Dr. Antonio Barros Neto. Apreciacao de Inscricao. Parecer da Comissao de Corpo Docente. (Procs. USP 89.1.1235.17.8 e 89.1.1283.17.9).

2. Concurso da Carreira Docente

Solicitacao de Abertura de Concurso

Concurso para provimento efetivo de 2 (dois) cargos de Professor Titular, Ref. MS6, em RDIDP, junto ao Departamento de Clinica Medica. Solicitacao de abertura de concurso. Parecer da Comissao de Corpo Docente. (Proc. FMRP 277/64).

3. Composicao de Comissoes Julgadoras pela CPG

Composicao de Comissoes Julgadoras propostas pela Comissao de Pos-Graduacao Mestrado:

a) Bacharel em Ciencias Biologicas Cleido Vasconcelos, Departamento de Fisiologia - Area de Fisiologia. Titulo da Dissertacao: "Modulacao neural da imobilidade tonica em sapos. Participacao do sistema colinergico".Homologacao das providencias tomadas pelo Senhor Diretor, "ad referendum" da Congregacao. (Proc. FMRP 199/87).

Doutorado:

a) Medico Mario Bastos, Departamento de Cirurgia, Ortopedia e Traumatologia - Area de Clinica Cirurgica. Titulo da Tese: "Avaliacao da funcao esofagiana pos-esclerose endospica das varizes do esofago - Estudo prospectivo controlado". (Proc. FMRP 89/83).

Fig. 5.13 - Pauta

Com a pauta registrada, a próxima etapa deve ser o registro das decisões tomadas na sessāo da Congregação, após sua realização. Para isso informa-se o número de sessāo de Congregação desejada e opta-se por Ata.

A opção Ata oferece um sub-menu, conforme já exibido na fig. 5.4. Ao optar por Expediente dever-se-á optar pelo item que se deseja, assim como ocorreu na pauta. Entretanto, agora será necessário informar o texto respectivo a cada item. 
A seguir, deve-se optar por Ordem do Dia (não é necessário que seja nessa ordem). Como já se tem o registro dos assuntos discutidos, fornecido quando se registrou a pauta, essa opção exibe o processo, o assunto, a descrição e os objetos e pede a decisão tomada. Em seguida, deve-se entrar com o texto que comporá a ata. As figuras 5.14 e 5.15 ilustram a entrada da decisão e do texto respectivamente. Analogamente, as decisōes e os textos de outos assuntos da ordem do dia serão informados.

Internamente, o sub-sistema consulta uma tabela, onde se registraram os assuntos de pauta, e com a informaçāo da decisão e do texto atualiza-se a tabela em que são registradas as instâncias de cada processo ativo. Além disso, o sub-sistema atualiza uma tabela onde se registra que assunto deve ser ligado com que assunto, isto é, que assunto dá continuidade a outro e estabelece uma ligação a ser feita no Hyperties.

\begin{tabular}{l}
\hline Sistema de Apoio a Reunioes da FMRP \\
\hline Ata - Informe sobre decisoes de ordens do dia \\
\hline 2-Concurso da Carreira Docente \\
Solicitacao de Abertura de Concurso \\
Concurso 2 (dois) cargos de Prof. Titulares. Depto Clinica Medica \\
Entre com a decisao: APROVAR
\end{tabular}

Fig. 5.14 - Entrada da Informação sobre a Decisão 
Ata - Informe sobre decisoes de ordens do dia

Entre com o texto (tecle ESC para terminar):

Abertura de concurso para provimento efetivo de 2 (dois) cargos de Professor Titular, Ref. MS-6, em RDIDP, junto ao Departamento de Clinica Medica, em decorrencia da aposentadoria do Professor Jose Augusto Figueiredo Filho e o falecimento do Professor Mario Vicente. Aprovacao do programa que servira de base ao concurso. Parecer da Comissao de Corpo Docente. Lembrando que a documentacao relativa fora distribuida como anexo da Ordem do Dia, o Senhor Presidente deu a palavra, em primeiro lugar, ao Presidente da C.C.D.. 0 Professor Francisco Ferreira Filho chamou atencao para um aspecto operacional do andamento desta abertura de concurso que ira coincidir com o andamento da realizacao do outro concurso junto ao mesmo Departamento. Outros membros presentes indagaram quais as razoes para a decisao da abertura antes da realizacao do concurso ja em andamento. O Professor Luis Motta referiu que esta foi uma decisao tomada pelo Conselho de Departamento que entendeu nao haver qualquer obice para a abertura do concurso para os dois cargos recem surgidos no Departamento. Ato continuo, o Senhor Presidente submeteu a votacao o item em tela, tendo o mesmo recebido aprovacao unanime (Proc. FMRP. 277/64).

Fig. 5.15 - Entrada do Texto sobre a Ordem do Dia

Ao término, pode-se imprimir a ata, conforme figura 5.16, e principalmente gerar a saída, isto é, um arquivo texto no formato Hyperties para ser importado por este (fig. 5.17) e, como se pode ver, constituído de marcadores - <, > - que serão interpretados pelo Hyperties..

O texto no formato Hyperties está agora pronto para ser importado pelo módulo de importação do Hyperties (Fig. 5.18). Issio significa que a indicação de ligação entre os assuntos de uma mesma sessão de Congregação já está feita. Ao importar esse texto, o Hyperties o adicionará à base de atas já existentes considerando a ligaçāo entre os assuntos dessa ata. Entretanto, a ligação desses assuntos aos já existentes na base não pode ser feita automaticamente. 
Ata da 533a. Sessao Ordinaria da Congregacao da Faculdade de Medicina de Ribeirao Preto.

No dia dezesseis de marco de mil novecentos e noventa, as quatorze horas e trinta minutos, foi realizada a 533a. Sessao Ordinaria da Congregacao, sob a Presidencia do Senhor Diretor Professor .... Secretariou a Sessao a Senhỏra Marcia Fernandes, Assistente para Assuntos Academicos da Faculdade.

\section{1a. PARTE - EXPEDIENTE}

1. Discussao e votacao da Ata da Sessao: 532a. Ordinaria

Havendo numero legal o Senhor Presidente colocou em discussao a Ata da 532a.

- Sessao Ordinaria. O medico Osvaldo Mendes solicitou correcao ... Sem comentarios a referida Ata obteve aprovacao unanime.

2. Comunicacoes do Senhor Presidente

o Senhor Presidente comunicou que: a) foram realizadas as seguintes eleicoes para representacao, junto a Congregacao ....

3. Palavra aos Senhores Membros da Congregacao

Com a palavra o Professor Roberto Santos Abreu inddagou ao Senhor Presidente qual sera a atitude da Presidencia deste Colegiado frente aos pedidos de inscricao aos concursos que virao para apreciacao. O Senhor Presidente....

2a. PARTE - ORDEM DO DIA

1. Concurso da Carreira Docente

Apreciacao de Inscricoes

Concurso para provimento efetivo de 1 (um) cargo de Professor Titular, Ref. MS-6, em RDIDP, junto ao Departamento de Fisiologia. Apreciacao das inscricoes dos candidatos: Profs. Dr. Helio Sanches e Dr. Antonio Barros Neto ... Em continuidade o Senhor Presidente determinou a distribuicao das cedulas para votacao .... o resultado significou a aceitacao pelo Colegiado de todas as inscricoes. (Procs. USP 89.1.1235.17.8 e 89.1.1283.17.9).

2. Concurso da Carreira Docente

Solicitacao de Abertura de Concurso

Abertura de concurso para provimento efetivo de 2 (dois) cargos de Professor Titular, Ref. MS-6, em RDIDP, junto ao Departamento de Clinica Medica, em decorrencia da aposentadoria do Professor Jose Augusto Figueiredo Filho e o falecimento do Professor Mario Vicente. Aprovacao do programa que servira de base ao concurso. Parecer da Comissao de Corpo Docente. Lembrando que a documentacao relativa fora distribuida como anexo da Ordem do Dia (f1s. 129 a 131), o Senhor Presidente deu a palavra, em primeiro lugar, ao Presidente da C.C.D. o Professor Francisco Ferreira Filho chamou a atencao para um aspecto operacional do andamento desta abertura de concurso que ira coincidir com o andamento da realizacao do outro Concurso junto ao mesmo Departamento. Outros Membros presentes indagaram .... Ato continuo, o Senhor Presidente submeteu 'a votacao o item em tela, tendo o mesmo recebido aprovacao unanime. (Proc.FMRP. 277/64).

3. Composicao de Comissoes Julgadoras pela CPG

Composicao de Comissoes Julgadoras propostas pela Comissao de Pos-Graduacao. Inicialmente, o Senhor Presidente indagou ao Presidente da Comissao de Pos-Graduacao,

- se ele desejava fazer algum comentario acerca das propostas de Comissoes Julgadoras de Mestrados e Doutorados. Como ele disse .... foram homologadas por unanimidade as comissoes juldoras de Mestrados e Doutorados que ficaram assim constituidas Mestrado:

Fig. 5.16 - Ata 
<IE>Ata $533<$ IE>

« $>$ Ata da 533a. Sessao Ordinaria da Congregacao da Faculdade de Medicina de Ribeirao Preto. $\backslash \mathrm{H}\rangle$

$<C>$ No dia dezesseis de marco de mil novecentos e noventa, as quatorze horas e trinta minutos, foi realizada a 533a. Sessao Ordinaria da Congregacao ....

$<\mathrm{L}>$ Expediente $1 / 533<\mathrm{L}>$

$\langle C>$

$\langle$ IE $>$ Expediente $1 / 533\langle$ IE $>$

$\langle\gg$ 1a. PARTE - EXPEDIENTE. Discussao e votacao da Ata da Sessao anterior $\backslash \mathbb{H}$

$\langle C>1$. Discussao e votacao da Ata da Sessao: 532a. Ordinaria. Havendo numero legal o

Senhor Presidente colocou em discussao a Ata da 532a. Sessao Ordinaria.... Sem

comentarios a referida Ata obteve aprovacao unanime.

$\langle>$ Ata $533<\mathrm{L}>$

$\langle$ I Expediente $2 / 533<$ L $>$

$\langle\mathrm{C}\rangle$

$\langle$ IE $>$ Expediente $2 / 533<\backslash$ IE $>$

$\langle\mathrm{la}$. PARTE - EXPEDIENTE. Comunicacoes do Senhor Presidente $\langle\mathrm{H}\rangle$

$<\mathrm{C}>2$. Comunicacoes do Senhor Presidente

- Senhor Presidente comunicou que:

representacao, junto a Congregacao ....

a) foram realizadas as seguintes eleicoes para

$<$ L Expediente $1 / 533<\backslash \mathrm{L}\rangle$

$<$ L $>$ Expediente $3 / 533<1 \mathrm{~L}>$

$\langle C>$

$<$ IE $>$ Expediente $3 / 533<$ IE $>$

$\langle\mathrm{H}>$ 1a. PARTE - EXPEDIENTE. Palavras aos Senhores Membros da Congregacao $\backslash \mathrm{H}\rangle$

$<C>3$. Palavra aos Senhores Membros da Congregacao

Com a palavra o Professor Roberto Santos Abreu inddagou ao Senhor Presidente qual sera a atitude da Presidencia deste Colegiado frente aos pedidos de inscricao aos

concursos que virao para apreciacao. o Senhor Presidente....

<L>Expediente $2 / 533<1 \mathrm{~L}>$

$\langle\mathrm{L}>$ Ordem do dia $1 / 533<\mathrm{L}>$

$\langle\mathrm{C}>$

$\langle$ IE $>$ Ordem do dia $1 / 533\langle$ IE $>$

$\langle\mathrm{H}>$ Concurso da Carreira Docente. Apreciacao de Inscricoes $\langle\mathrm{H}\rangle$

$<D>$ Concurso da Carreira Docente. Apreciacao de Inscricoes. Concurso de 1 (um) cargos de Prof. Titular. Depto Fisiologia< $\backslash D>$

$<C>1$. Concurso para provimento efetivo de 1 (um) cargos de Professor Titular, Ref. MS6, em RDIDP, junto ao Departamento de Fisiologia. Apreciacao das inscricoes dos

candidatos: Profs. Dr. Helio Sanches e Dr. Antonio Barros Neto. Parecer da Comissao de Corpo Docente....

<L Expediente $3 / 533<\backslash \mathrm{L}$

$\langle\mathrm{L}>$ Ordem do dia $2 / 533<\mathrm{L}\rangle$

$\langle\mathrm{C}\rangle$

$\langle$ IE $>$ Ordem do dia $2 / 533<$ IE $>$

$\ll>$ Concurso da Carreira Docente. Solicitacao de Abertura de Concurso $\backslash \mathrm{H}\rangle$

$\triangle>$ Concurso da Carreira Docente. Solicitacao de Abertura de Concurso. Concurso 2 (dois) cargos de Professor Titular. Depto C1inica Medica< $\backslash D>$

$<C>2$. Abertura de concurso para provimento efetivo de 2 (dois) cargos de Professor Titular, Ref. MS-6, em RDIDP, junto ao Departamento de Clinica Medica, em decorrencia da aposentadoria do Professor Jose Augusto Figueiredo Filho e o falecimento do Professor Mario Vicente .... Ato continuo, o Senhor Presidente submeteu a votacao o item em tela, tendo o mesmo recebido aprovacao unanime. (Proc.FMRP. 277/64).

$\langle>0$ rdem do dia $1 / 533\langle\downarrow\rangle$

Fig. 5.17 - Texto da Ata no Formato Hyperties 
Para ser possivel ligar os assuntos atuais aos já existentes na base de dados hipertexto, deve-se entrar no módulo de autoria do Hyperties e selecionar a base que se deseja atualizar conforme se vê na figura 5.19. Ao se selecionar a base (a figura 5.19 mostra somente uma base), é apresentado um índice remissivo contendo os nomes de todos os artigos (Fig. 5.20), inclusive dos que acabaram de ser importados. Para se estabelecer as ligações dos artigos mais recentes aos já existentes, deve-se invocar o artigo pelo seu nome o que resultará numa tela, conforme figura 5.21, onde o texto - incluindo-se suas demais características - pode ser visto e editado e, então, optar-se por SAVE-RESOLVE que possibilita a ligação do artigo em questão aos outros da base.

\begin{tabular}{|c|c|}
\hline \multirow{2}{*}{$\begin{array}{l}\text { Source } \\
\text { Directory: } \\
\text { AIM Files: }\end{array}$} & C: ITESEICONGREGA \\
\hline & ATA533.AIM \\
\hline \multirow{2}{*}{$\begin{array}{r}\text { DESTINATION } \\
\text { Directory: } \\
\text { knowledge Base: }\end{array}$} & C:ITESEICONGREGA \\
\hline & CONGREGA \\
\hline $\begin{array}{l}\text { LOG } \\
\text { File Name: } \\
\text { Links: } \\
\text { Article Overurites: }\end{array}$ & 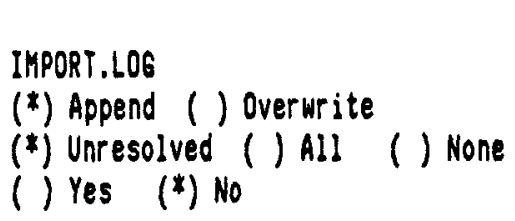 \\
\hline
\end{tabular}

Enter the 8 character filenane for the destination knowledge base. Fl-Help
F10-Continue
ESC-Cancel

Fig. 5.18 - Tela Inicial do Módulo de Importação do Hyperties 


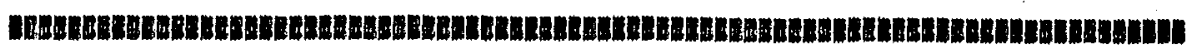

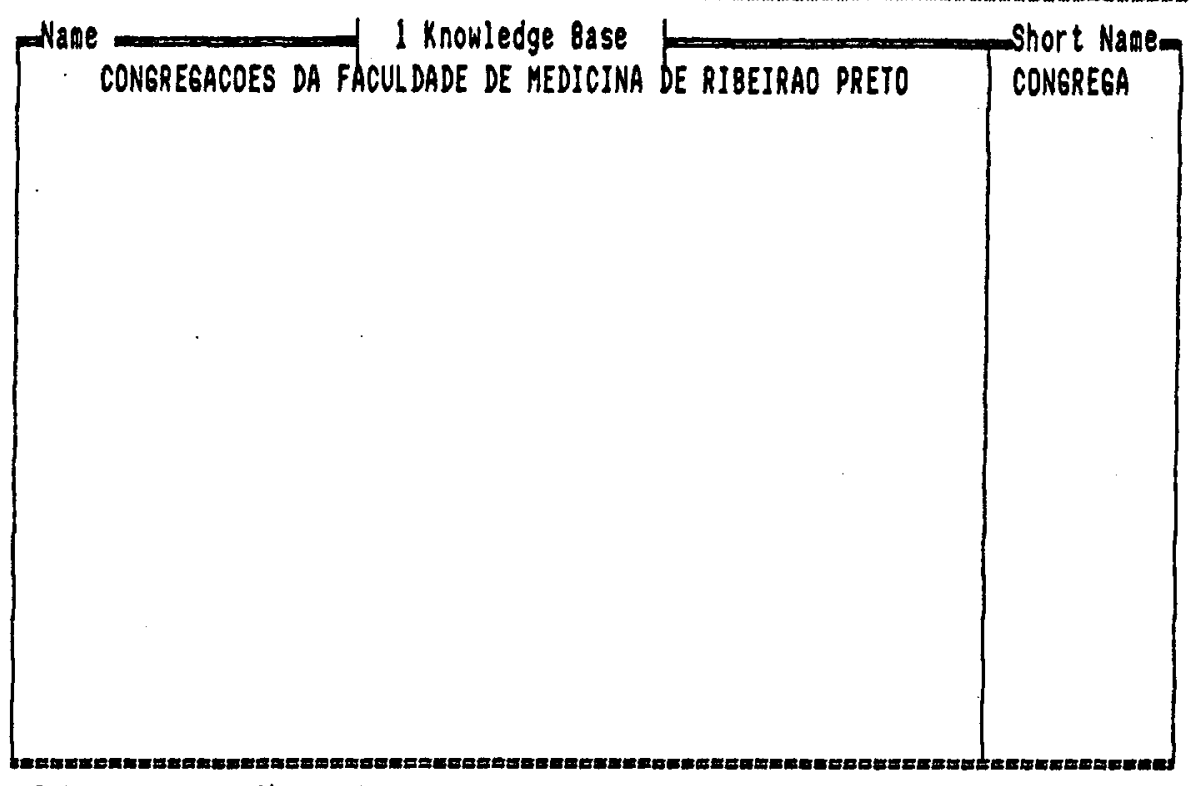

Select New Change-Directory

LIST

HELP-(FI) TOOLS QUIT

Fig. 5.19 - Módulo de Autoria do Hyperties. Seleção da Base

INDEX OF ARTICLES CONGREGACOES DA FACULDADE DE MEDICINA DE RIBEIRAO PRETO

Graphics

Font-Table

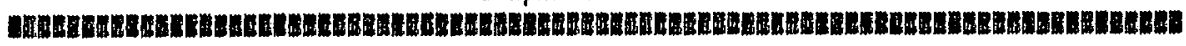

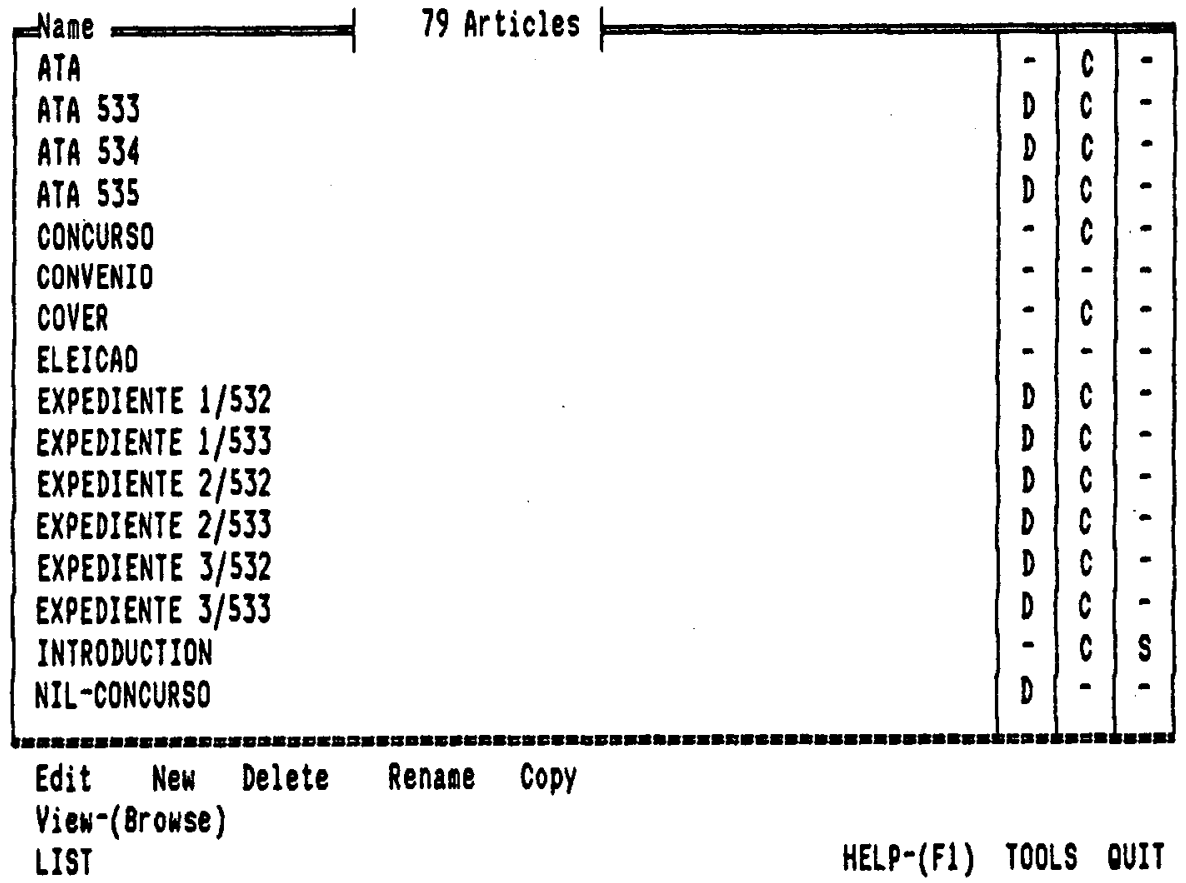

Fig. 5.20 - Módulo de Autoria do Hyperties. Índice de Artigos 


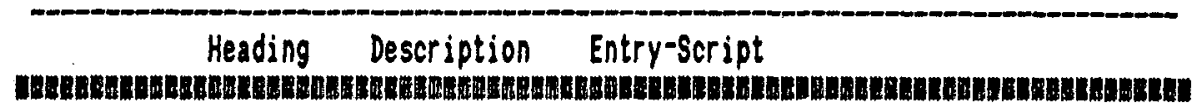

CONTENT

2. Abertura de concurso para provinento efetivo de 2 (dois) cargos de Professor Titular, Ref. MS-6, en RDIDP, junto ao Departamento de Clinica Medica, en decorrencia da aposentadoria do Professor Jose Augusto Figueiredo Filho e o falecimento do Professor Mario Vicente. Aprovacao do programa que servira de base ao concurso. Parecer da Conissao de Corpo Docente. Lembrando que a documentacao relativa fora distribuida como anexo da orden do dia ( $f$ )s. 129 a 131), o senhor Presidente deu a palavra, en primeiro lugar, ao Presidente da C.C.D.. O Professor Francisco Ferreira Fijho chamou a atencao para un aspecto operacional do andamento desta abertura de concurso que ira coincidir com o andamento da realizacao do outro concurso junto ao mesmo Depar tamento. Outros Membros presentes indagar an .... Ato continuo, o Senhor Presidente submeteu 'a votacao o item en tela, tendo o mesno recebido aprovacao unanine. (Proc. FMRP. 277/64).

<L) Orden do dia $7 / 533\langle\backslash L=\$ 94\rangle$

$\langle L\rangle$ Ordem do dia $9 / 533\langle\backslash L=\| 96\rangle$

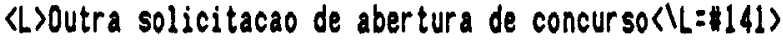

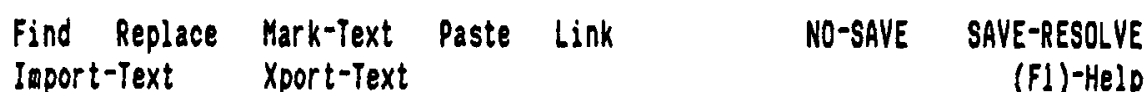

Fig. 5.21 - Módulo de Autoria do Hyperties. Edição de Artigo

Como se vê, na figura 5.22, ao texto foram acrescentadas expressões que serão as marcas de ligação, no caso do exemplo: para a ordem do dia anterior e posterior a essa em questão; para o assunto igual e anterior a esse (Solicitação de Abertura de Concurso); e, se fosse o caso, para o assunto anterior a esse, mas do mesmo processo e da mesma instância. Por exemplo, quando se entrar com o assunto Apreciação de Inscrições dessa mesma instância, ele deverá ter uma expressão em seu texto ligando-o a esse em questão (Solicitação de Abertura de Concurso). O programa de apoio inclui essas palavras ou expressões no texto. 


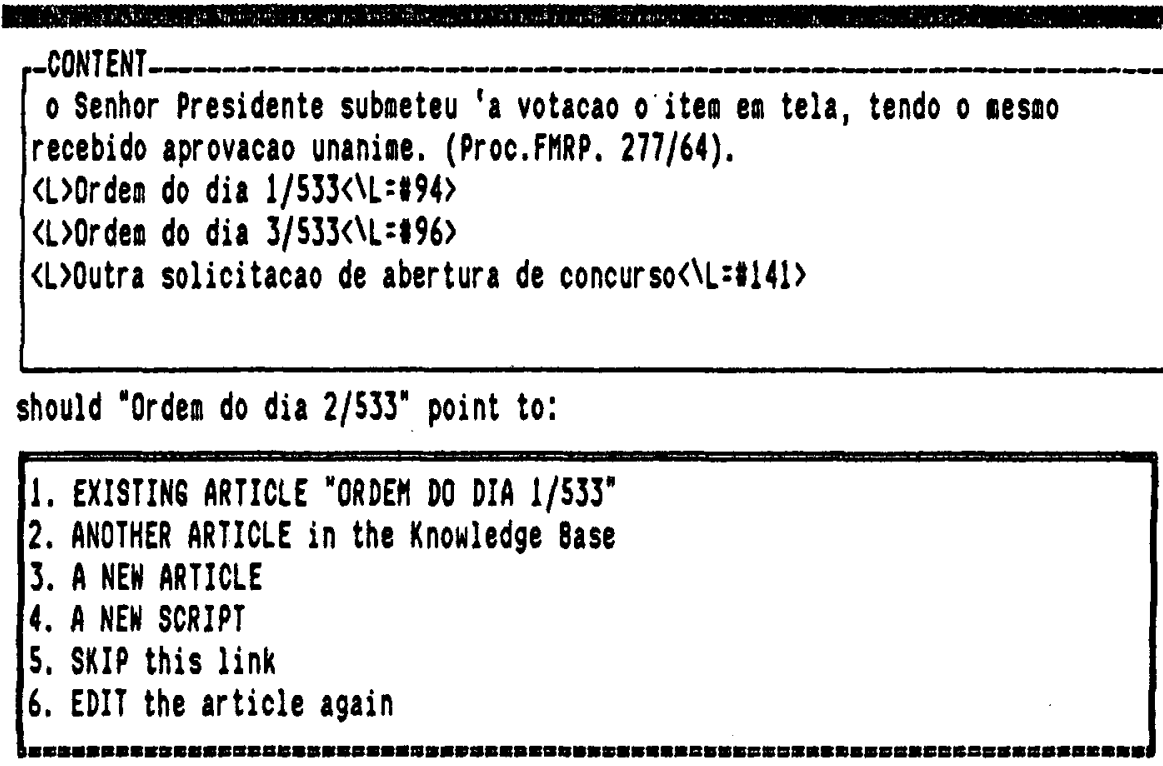

ESC will also let you edit the article again

Fig. 5.22 - Módulo de Autoria do Hyperties. Ediçáo de Artigo

O procedimento acima possibilita as ligações, mas é necessário conhecer o outro assunto, já na base, com o qual o assunto em questão irá se ligar. Para isso, o sistema específico, na opção Ata, fornece um relatório das ligaçōes a serem estabelecidas. Tal relatório (Fig. 5.23), informa o assunto atual e com qual ele deve se ligar. $\mathrm{O}$ assunto é identificado pelo seu nome, formado pela palavra ORDEM DO DIA ou EXPEDIENTE, mais o número do expediente ou da ordem do dia e o número da sessão de Congregação. $O$ usuário, então, trabalha com base nesse relatório para estabelecer as ligações.

Conforme se verá no próximo item deste capítulo, a navegação pela base sempre é iniciada por uma tela padrão do Hyperties, na qual somente se informa o título da base. A partir dessa tela chega-se a outra, também padrāo, que contém algumas explicações sobre a base e sobre algumas opções do Hyperties (Fig. 5.24). 
Nessa tela, ao optar-se por Inicio, pode-se percorrer as atas pelas várias ligações que foram definidas. Cada uma dessas ligações é representada por palavras ou expressōes, como um sumário, e o usuário começa a navegar pela que the for mais conveniente.

Cada uma dessas palavras ou expressões leva o usuário à última ocorrência daquele processo ou assunto. Dessa maneira, o relatório fornecido pelo programa de apoio também deve alertar o usuário para atualizar essas ligações. Por isso se vê em algumas linhas do relatório (Fig. 5.23) palavras ou expressōes como origem e assunto como destino.

Relatorio de Apoio para Ligacoes

Ata 533 com Base Hipertexto de Atas

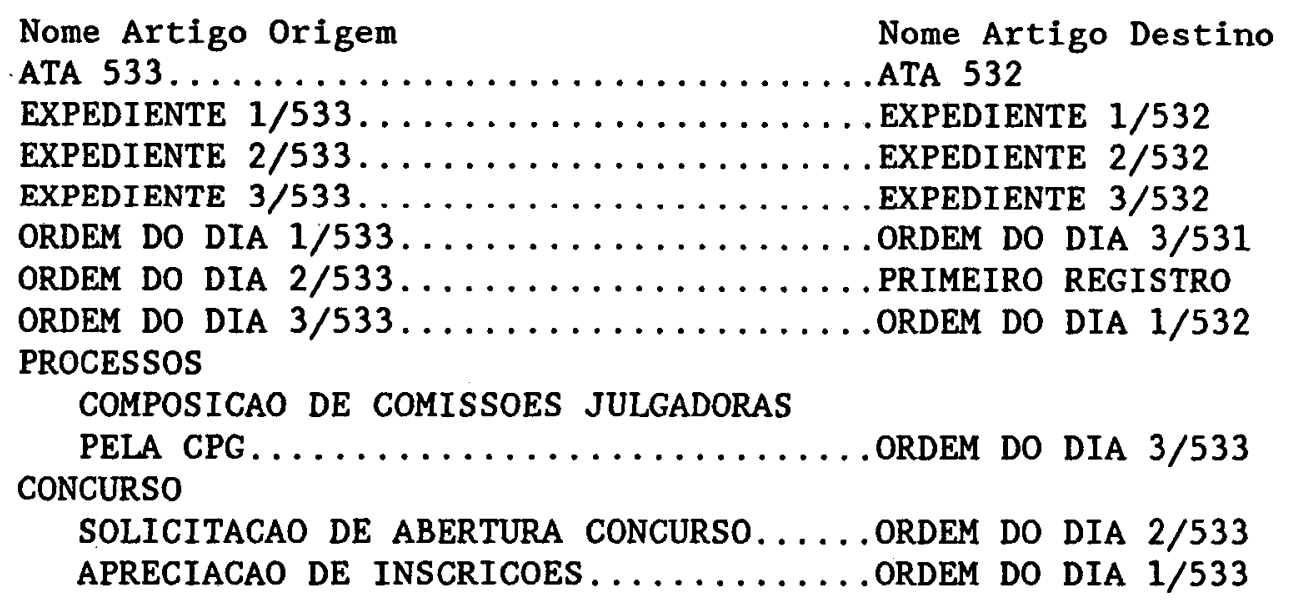

Fig. 5.23 - Relatório de Ligaçōes 


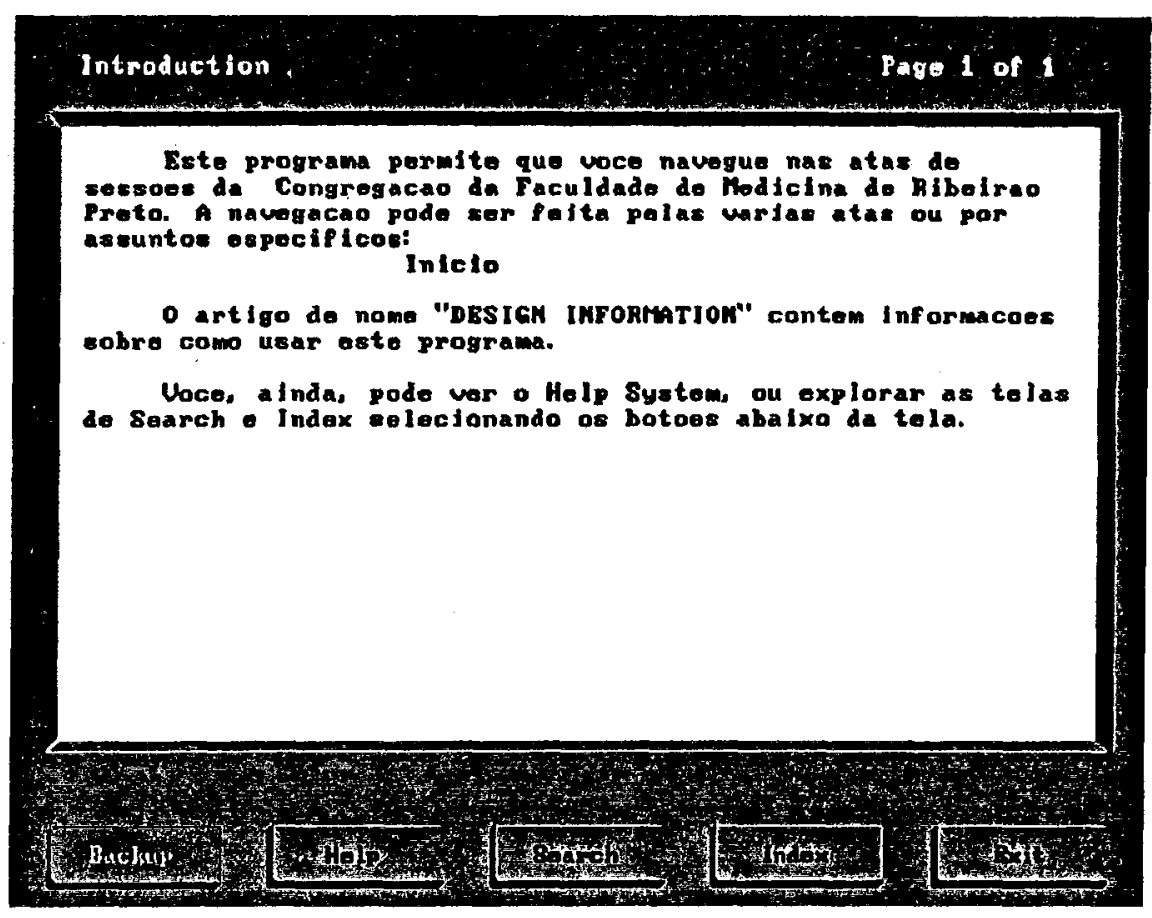

Fig. 5.24 - Módulo de Navegação do Hyperties. Tela Inicial

Feita a importação e as ligações manualmente, a base está atualizada e pronta para ser navegada. Como se vê, esse procedimento não pode ser totalmente automático, pois os sistemas de hipertexto, em geral, não apresentam mecanismos para se definir a estrutura e comportamento dos documentos e, além disso, não contam com editores de textos com recursos como, por exemplo, de acentuação ou de definição de tipos de letras.

\subsection{Navegação}

A navegação pela base de dados hipertexto é feita totalmente através do módulo de navegação do Hyperties que, na versão utilizada, oferece uma apresentação padrāo em relação ao formato e cor da tela e opções.

Para a navegação deve-se executar o programa BROWSER do Hyperties com a designaçāo da base de dados hipertexto a ser navegada. Essa invocação faz 
com que uma tela de apresentação seja exibida ao usuário, conforme figura 5.25, contendo opções para se iniciar a navegação pela base, Enter Knowledge Base, ler explicaçōes sobre a base, About This Knowledge Base, e explicaçōes de como usar o programa, Help. No topo vê-se o título dado a essa base pelo autor. Tem-se a impressão de se estar iniciando a leitura de um livro e essa tela ser sua capa.

A opção About This Knowledge Base leva o usuário a uma tela com um texto sobre as possibilidades de se percorrer a base de atas de congregaçōes, $o$ ano a partir do qual se tem as atas na base e as pessoas envolvidas no projeto. Normalmente o texto é apresentado numa janela que se sobrepõe à tela da figura 5.25 com a opção de remoção e retorno à tela anterior, isto é, é um artigo Hyperties que só contém descrição. Já a opção Help, leva a um texto com possibilidades de opção para outros textos e assim por diante, todos contendo explicaçōes de como se usar o programa. Essa estrutura já vem implementada pelo Hyperties, em inglês, entretanto, tem-se acesso a todos os textos e pode-se eliminar, alterar ou incluir textos.

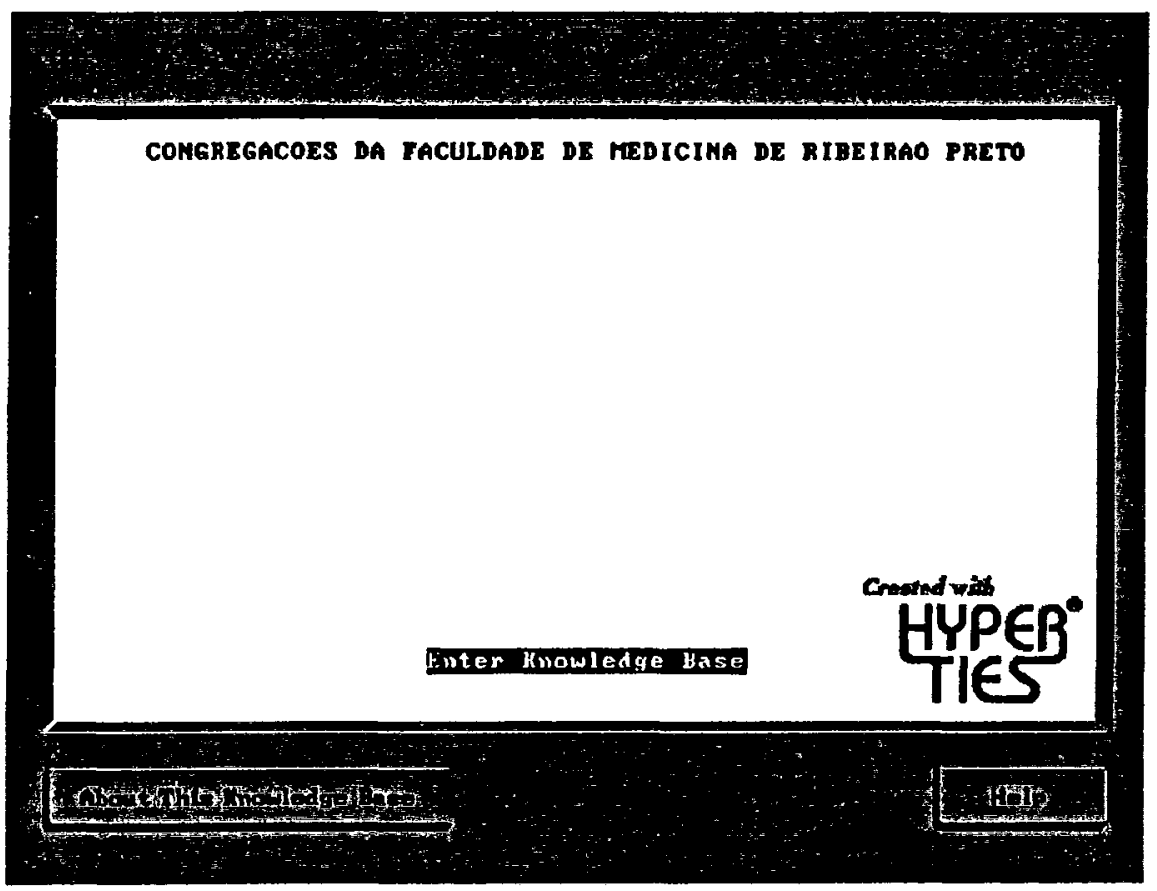

Fig. 5.25 - Módulo de Navegação do Hyperties. Capa 
Através da escolha da ligação, ou opção, Enter Knowledge Base, é que se inicia a leitura da base. Essa opção liga-se a um artigo padrão de introdução (Fig. 5.24) que pode conter um texto sobre informações gerais da base, duas ligações, Design Information e Help System, para artigos padões do Hyperties e, ainda, uma terceira que permitirá que o usuário inicie a leitura.

A figura 5.26 mostra a tela a que se chega caso o usuário tenha seguido pela ligação Inicio na tela anterior (Fig. 5.24). Vê-se uma tela com diversas palavras e expressões, como um índice, que são ligações para o último assunto do mesmo tipo discutido em sessão de congregação. Por exemplo, ao se seguir pela ligação Comunicações do Senhor Presidente chega-se à sessão de Congregação mais recente que tenha esse assunto em ata.

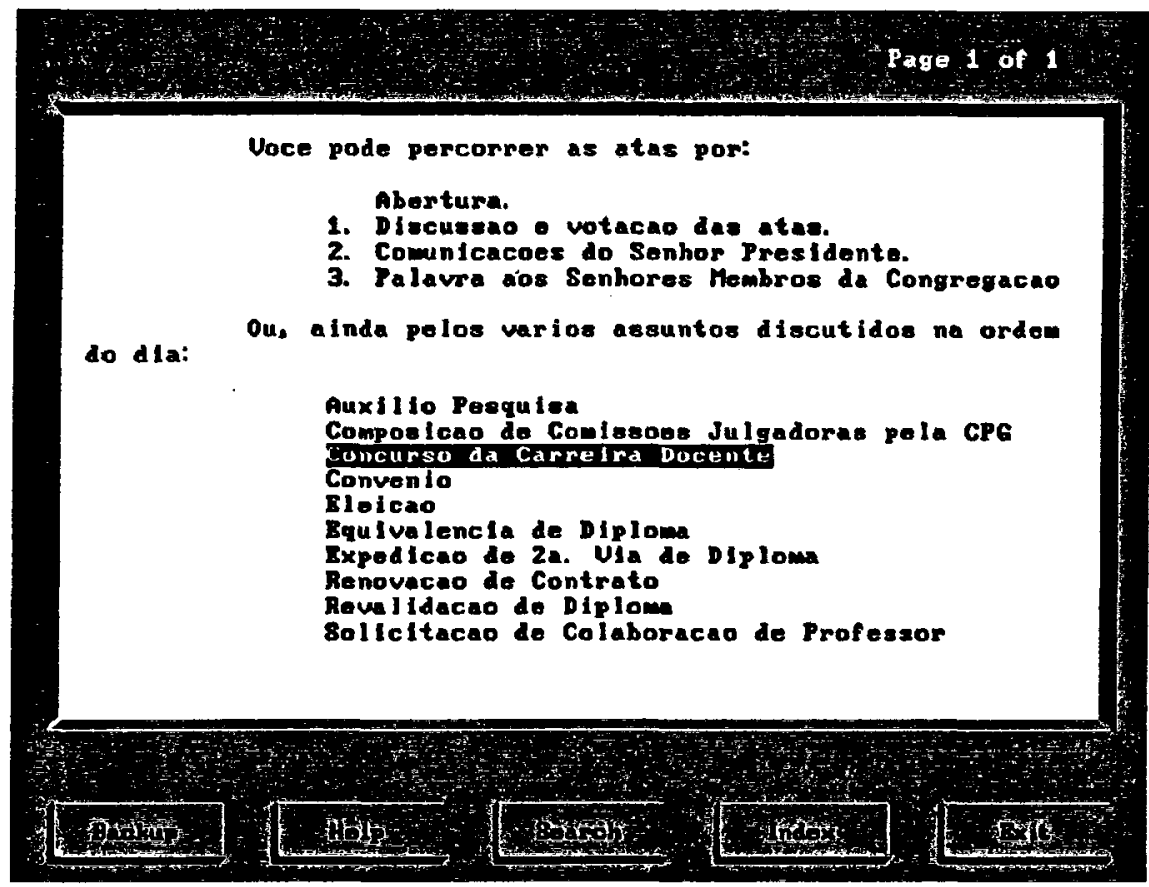

Fig. 5.26 - Módulo de Navegação do Hyperties. Principais Ligações 
Já ao optar-se por Concurso da Carreira Docente, que é um processo constituído de vários assuntos, depara-se, inicialmente, com uma tela com possibilidades de se seguir pelos vários assuntos que o compõe, conforme figura 5.27. Ao se decidir seguir por Solicitação de Abertura de Concurso chega-se a um trecho da ata mais recente com esse assunto, conforme se vê na figura 5.28. A figura 5.29, que se alcança seguindo por Next Page, visto na figura anterior, mostra as ligaçōes que se pode seguir a partir desse artigo, que contém a discussão de uma ordem do dia. Se se optar por Outra Solicitação de Abertura de Concurso chega-se a um trecho da ata mais recente, em relação a esta em que se está, contendo esse mesmo assunto e assim por diante até se alcançar a primeira ocorrência desse assunto que se liga a um texto com messagem de que não existe mais nenhuma solicitação de abertura de concurso, conforme figura 5.30. A opção Back permite que se retorne à tela anterior e assim por diante.

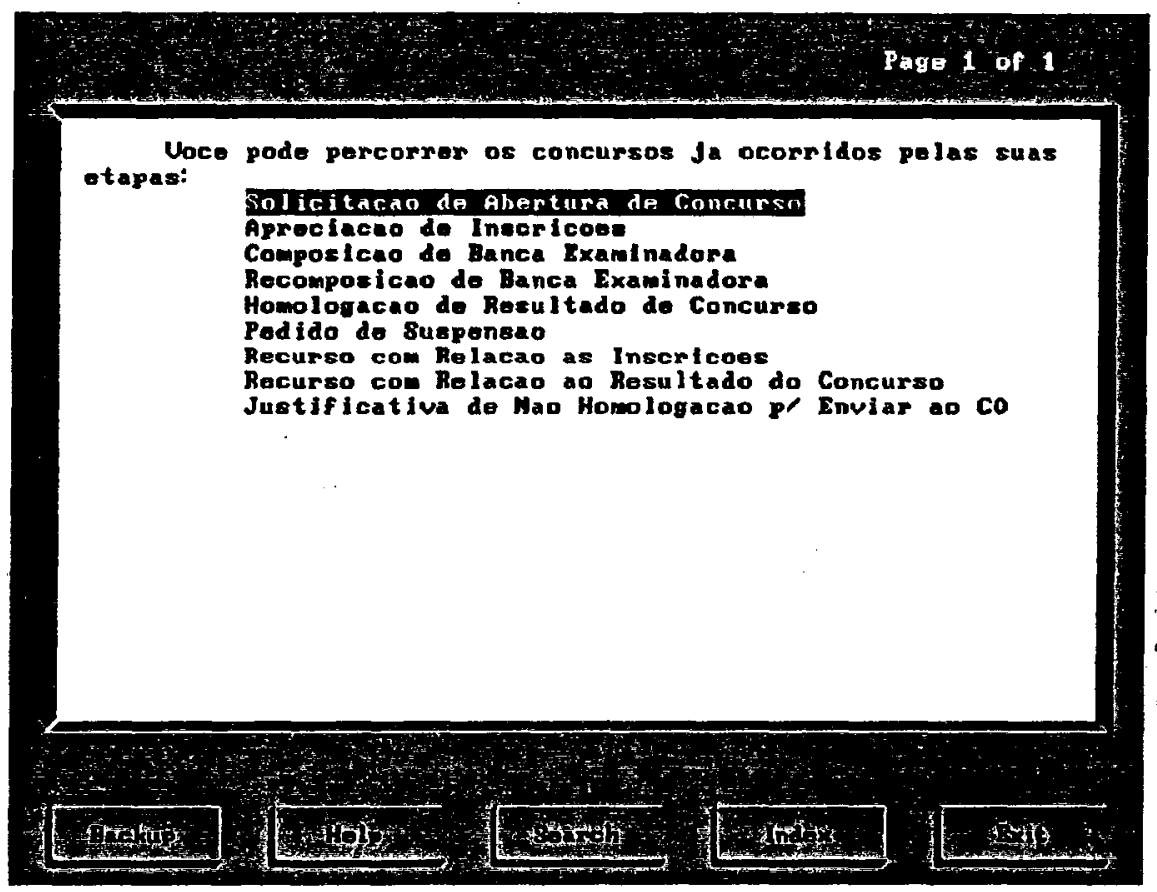

Fig. 5.27 - Módulo de Navegação do Hyperties. Ligaçōes para os Vários Assuntos do Processo Concurso da Carreira Docente 


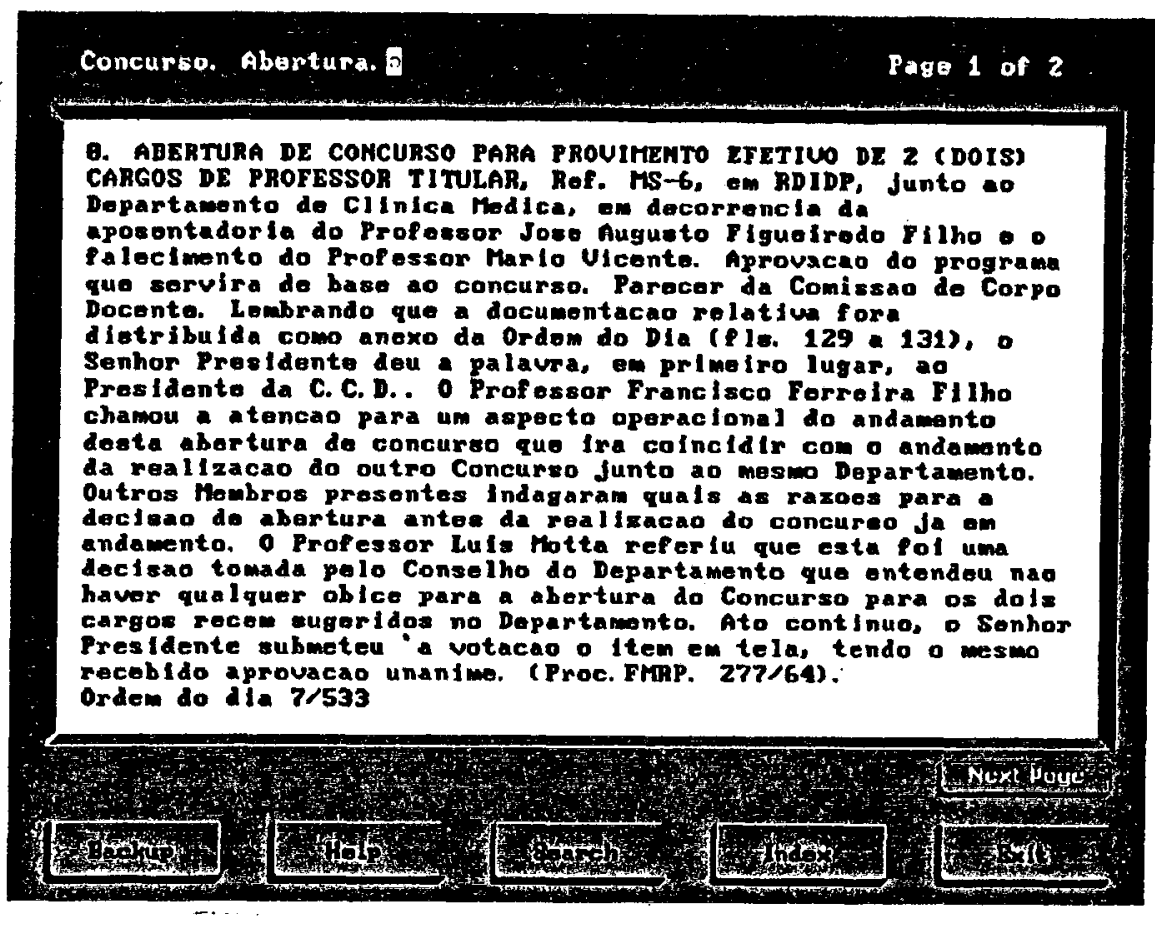

Fig. 5.28 - Módulo de Navegação do Hyperties. Ordem do Dia. Solicitação de Abertura de Concurso

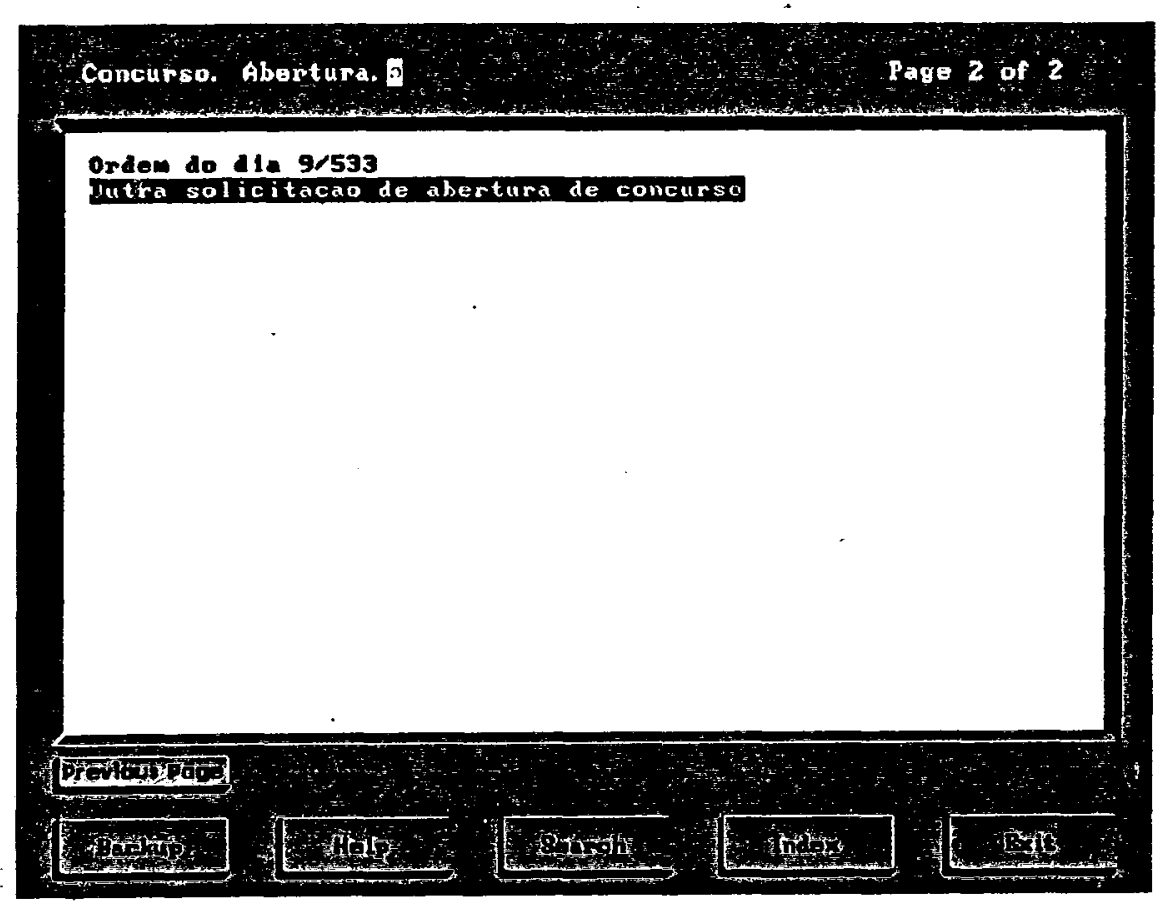

Fig. 5.29 - Módulo de Navegação do Hyperties. Ordem do Dia. Solicitação de Abertura de Concurso.

Continuação 


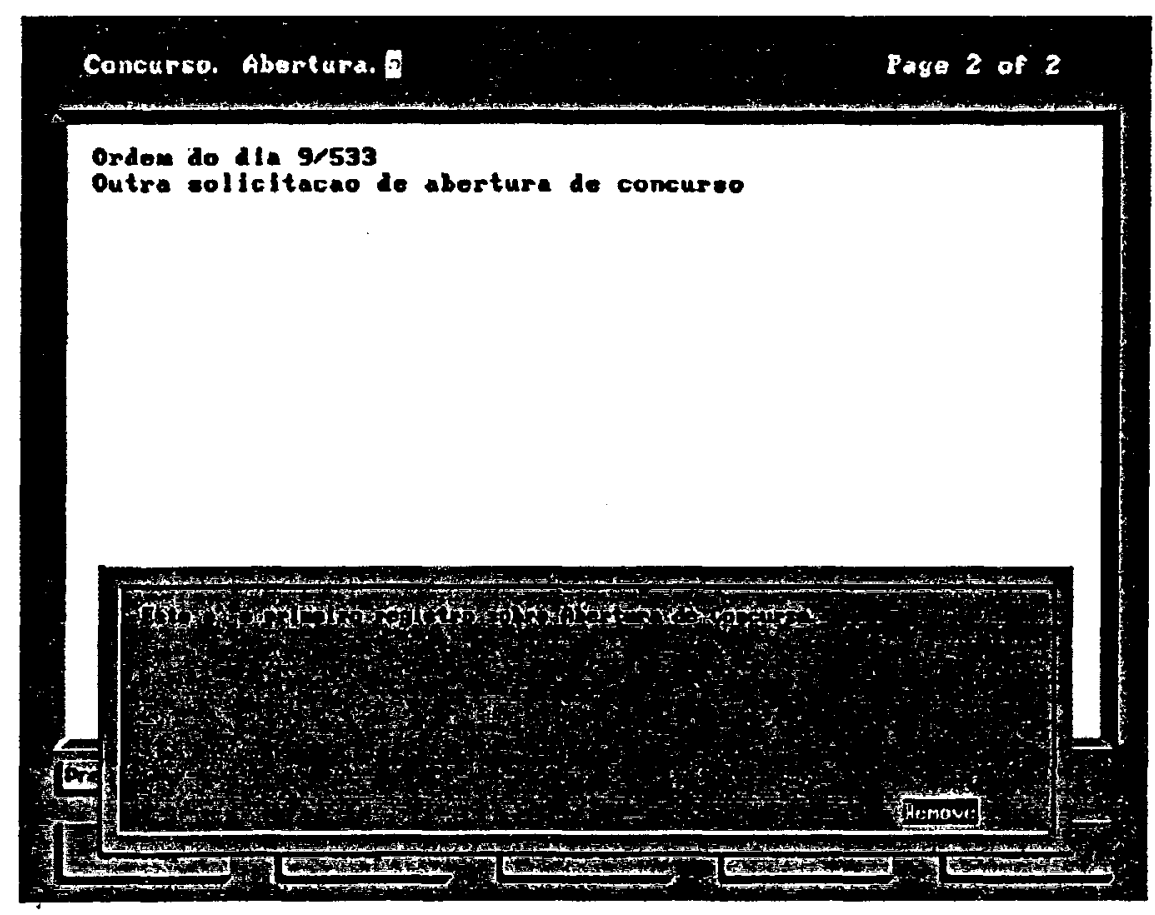

Fig. 5.30 - Módulo de Navegação do Hyperties. Menssagem de Primeiro Assunto

Ao optar por Homologação de Resultado de Concurso, na figura 5.27, chegase a um trecho de ata com discussāo desse assunto que por sua vez deverá ter ligaçōes análogas a Solicitação de Abertura de Concurso. Entretanto, como não é o primeiro assunto de um processo, ele poderá apresentar mais uma ligação, a qual será para o assunto do processo que acontece antes dele, no caso, Composição de Banca Examinadora, Recomposição de Banca Examinadora, Recurso com Relação ao Resultado do Concurso ou mesmo Homologação de Resultado e Concurso, conforme o diagrama da figura 4.2.

Pode-se, ainda, através da opção SEARCH do BROWSER, fazer a busca por qualquer palavra ou expressão. Essa opção relaciona todos os nomes de artigos em que encontra a palavra ou expressão fornecida. E através da opção INDEX, que 
relaciona todos os nomes de artigos em ordem alfabética, pode-se ir diretamente a um artigo conhecendo-se seu nome. Essa possibilidade é pouco provável, a não ser que se tenha optado por SEARCH antes, pois os nomes são todos formados pela palavra EXPEDIENTE ou ORDEM DO DIA, dependendo do caso, mais o seu número e o número da sessão de Congregação, como já descrito na seção anterior. Dessa forma é difícil para o usuário, interessado em determinado trecho da ata, lembrar-se em que ata ou ordem do dia, por exemplo, determinado assunto ocorreu.

Assim como no módulo de autoria, no módulo de navegação também foram encontradas algumas dificuldades. Não estão disponíveis ferramentas, por exemplo, para realizar pesquisas que envolvam quantidades, médias ou totalizações. Além disso toda saida é feita em tela, a única possibilidade de saída em impressora é de artigos.

5.4 Sugestão de Recursos a Serem Incorporados aos Sistemas de Hipertexto.

O sistema de hipertexto utilizado neste trabalho foi o Hyperties, que é representativo dessa classe de software, apresentando a maioria das ferramentas encontradas em outros sistemas de hipertexto, com algumas vantagens ou desvantagens em relação aos outros. Entretanto, independente dessas pequenas diferenças, pode-se determinar através dele os recursos oferecidos por um sistema de hipertexto, principalmente, autoria e navegação. E, como se pode observar, ainda há muito a ser desenvolvido.

O sistema de hipertexto Hyperties, ou outro qualquer, apresenta um módulo de autoria onde o autor precisa, num estágio muito inicial, definir os nós, ligações e 
toda a estrutura do documento que está criando. De acordo com Streitz, em [St90], experiências com o NoteCards

mostraram que isso normalmente resulta numa organização prematura, pois conforme o autor começa a expor suas idéias é que percebe a estrutura que gostaria que o texto tivesse. Nesse sentido, o método apresentado neste trabalho auxilia o autor para estruturar suas idéias.

Entretanto, o ideal seria que os sistemas de hipertexto permitissem a inclusão de um conjunto de padrões para descrição de estruturas de documentos, através do qual seria possível, de uma maneira formal, a tradução de um documento linear para o formato hipertexto.

Outra caractetística importante num sistema de hipertexto seria a inclusão, também, de um conjunto de regras para a descrição do comportamento do documento ou de partes dele. Por exemplo, o programa de apoio a reuniōes de Congregação trabalha internamente com uma tabela que representa os vários diagramas de estado e outra que representa as instâncias dos vários processos ativos e, então, com base nisso determina as ligaçōes. Se essa característica estivesse embutida no Hyperties, bastaria a descrição dos diagramas para que as ligações no módulo de autoria fossem feitas de forma completamente automática.

As duas características apresentadas poderiam resolver o problema de se ter um ou vários documentos para serem traduzidos ou escritos no formato hipertexto, de uma única vez ou não. Porém, ainda é necessário solucionar o problema de um autor criando um texto que será usado por outra pessoa para aprender algo. Para isso seria preciso a inclusão de ferramentas de autoria com componentes que permitissem a monitoração e a análise das atividades do autor. Tais ferramentas devem estar embasadas em modelos que apoiam o ato de escrever, como descreve Streitz, em [St90]. 
Já o módulo de navegação apresenta muitas características importantes e que satisfazem o usuário. Entretanto, observa-se, principalmente para o trabalho, que é importante que o recurso de busca ofereça possibilidades de impressão e até de quantificaçâo. E nesse caso as facilidades oferecidas são poucas ou nenhuma.

Se uma base de dados hipertexto é formada por textos ou figuras como, por exemplo, Glasgow Online, descrito por Harman em [Ha89], e usada por usuários em busca, geralmente, de uma informação objetiva como, por exemplo, quais os hotéis da cidade, as características de navegação se incorporam muito bem. Os usuários, desde que um pouco experientes com esse tipo de aplicação, sentem-se à vontade para ir e vir pelas ligaçōes encontrando somente alguma dificuldade na interface, já que nem sempre uma palavra, expressão ou pedaço de figura é claramente apresentada como uma ligação.Encontrada a informaçāo o problema está resolvido.

Já uma aplicação que apresenta uma base de dados com informação mais estruturada e repetitiva como, por exemplo, este trabalho onde concurso da carreira docente passa por etapas mais ou menos previsíveis e várias vezes acontece um concurso, o módulo de navegação deve fornecer possibilidades de quantificação, já que pode-se desejar saber quantos concursos ocorreram em terminado período. Isto é, juntamente com a possibilidade de se seguir pelas ligações, os sistemas de hipertexto poderiam oferecer alguns recursos dos sistemas gerenciadores de base de dados tradicionais.

Inevitavelmente os sistemas de hipertexto tornar-se-ão cada vez mais efetivos e usados por leitores e autores e um modelo padrão de hipertexto deve ir além dos que estão disponíveis atualmente, empregando melhor sua capacidade de múltiplos tipos de nós e ligaçōes. 


\subsection{Considerações Finais}

Pretendeu-se nesse exemplo demonstrar e analisar o uso do sistema para processos constituídos de um ou vários assuntos e destacou-se, ainda, a ligação entre vários assuntos solicitação de abertura de concurso.

Com a demonstração, observa-se que o procedimento que envolve a entrada das informaçōes da pauta e da ata - sub-sistema de preparação -, o que fez a conversão do texto da ata e o que permitiu a construção das ligações não são totalmente automáticos e, ainda, são procedimentos realizados por dois aplicativos diferentes, um desenvolvido em Clipper e outro em Hyperties. Isso deve-se ao fato dos sistemas de hipertexto atuais não apresentarem ferramentas adequadas para a autoria da base hipertexto.

Tais ferramentas, que não parecem triviais, deverão ser incorporadas aos sistemas de hipertexto para que essa situação seja melhorada no futuro e os hipertextos sejam utilizados mais intensamente. 


\section{Conclusões}

\subsection{Considerações Iniciais}

O trabalho apresentado permite um apoio efetivo a reuniões formais, caracterizadas por emissão de circular de convocação previamente a reunião e confecção de ata, atividade de um escritório em que se emprega muito tempo. Ele se direciona para o registro das opiniōes dos participantes e, principalmente, das decisões tomadas, além de permitir as pesquisas que frequentemente precisam ser feitas sobre os assuntos discutidos e suas decisōes.

O hipertexto, a partir de sua estrutura de nós e ligações, facilitou o desenvolvimento deste trabalho, já que fornece um bom sistema de navegação, além de ser fácil de ser aprendido e usado.

Os documentos gerados por essas reuniōes apresentam uma estrutura explícita e padronizada, possibilitando a importação automática para o sistema de hipertexto usado, com o auxílio de um sub-sistema de preparação das informações. 
Dessa maneira, garante-se, por exemplo, que todos os assuntos discutidos fiquem associados aos mesmos assuntos discutidos em reuniões anteriores.

Para exemplificar essa aplicação dos sistemas de hipertexto à automação de escritórios, foram consideradas as reuniões de Congregação que acontecem em algumas instituições da USP, especificamente as da Faculdade de Medicina de Ribeirão Preto.

\subsection{Contribuições deste Trabalho}

$\mathrm{Na}$ literatura especializada há um grende número de trabalhos publicados sobre hipertextos. Muitos, conceituando-os, descrevendo com detalhes sua ferramenta para navegação através do texto e utilizando-os para aplicações que, de certa forma, não serão modificadas.

Essas aplicaçōes visam, geralmente, a criação de uma base de dados sobre um assunto específico. Essa base de dados não é acrescida de informações em períodos regulares, mas ela é apenas atualizada se necessário. Sua principal característica é permitir várias consultas como, por exemplo, o sistema Glasgow Online, em [Ha89], que serve para turistas e moradores de uma cidade se orientarem sobre localizações de ruas, lojas, restaurantes, hotéis, cinemas, etc., ou, então a aplicação para museus, descrita em [Sh89], que fornece explicações sobre o que está exposto.

Uma vez montada a base de dados num sistema de hipertexto, esta só será modificada caso seja, por exemplo, construido um novo hotel na cidade ou, ainda, o museu adquira um nova peça para ser exposta. Nesses trabalhos, então, pouca importância se deu para o problema da atualização, ou ampliação, da base de dados após sua criação e liberação para consultas. 
Poucos trabalhos estavam voltados para uma aplicaçāo que exigisse um esforço de atualização constante do seu autor e consequentemente de ferramentas de autoria. Destaca-se aqui o projeto gIBIS, em [Co88], desenvolvido para apoiar o processo de projeto de programas complexos que não podem ser solucionados pela abordagem tradicional da análise sistemas.

Este trabalho contribui para a pesquisa sobre hipertexto por apresentar uma aplicação onde a sua base de dados necessita ser periodicamente atualizada com um volume muito grande de informações e por apresentar uma solução para a autoria criação e manutenção - da base de dados.

O método proposto auxilia a criação de uma base constituída de informações com estruturas explícitas, padronizadas e relacionadas entre si. E de acordo com Glushko, em [Gl89], a criação de uma base de documentos em hipertexto com quantidades realísticas de textos e gráficos é um problema que requer métodos disciplinados para a caracterização da estrutura física e lógica dos documentos.

O uso de sistemas de hipertexto para a solução de problemas na área de automação de escritório, especificamente de sistemas de armazenamento e recuperação de documentos, é inovador. Até recentemente, os problemas dessa área foram solucionados pela abordagem tradicional de desenvolvimento de sistemas. E, também, o trabalho de apoio a reuniões com o auxílio do computador só há pouco tempo passou a ser possível.

Podia-se ter realizado todo esse trabalho através da abordagem tradicional de desenvolvimento de sistemas, mas certamente isso implicaria no sacrifício das pesquisas pelo usuário ou na complexidade da programação, já que o usuário quer ter acesso a trecho de textos e não somente a resultados numéricos ou tabulados. Usar a ferramenta de navegação proporcionada pelo hipertexto é excitante para o usuário novato ou experiente que decide por onde seguir pelo texto ou pesquisar o que achar melhor. 
Enfim, o trabalho apresenta contribuiçōes tanto para o problema de autoria, que de acordo com Salgado e outros, em [Sa92], ainda não está claro o que fazer para se criar um documento em um sistema de hipertexto, como para o problema de revisão de decisōes no âmbito de automação de escritórios. Além disso, o trabalho vai de encontro as necessidades do usuário que imagina sentar-se diante de um computador e não ficar restrito aos relatórios que o programa pode lhe fornecer.

\subsection{Sugestões de Novas Pesquisas}

Um problema encontrado para o apoio a reuniōes utilizando sistemas de hipertexto foi a autoria da base, isto é, a inclusão de novas informações que deveriam ligar-se a outras já existentes na base. Esse problema, como descrito no capítulo anterior, foi solucionado desenvolvendo-se sub-sistemas de apoio e utilizando-se de uma ferramenta de importação de informações para a base de dados hipertexto. O procedimente não é totalmente automático.

Entretanto, pesquisas podem ser desenvolvidas para implementar as sugestões também apresentadas no capítulo anterior, isto é, é possível incluir a um sistema de hipertexto mecanismo que possibilite a ligação automática da informação a ser incluida com as já existentes na base, facilitanto assim o trabalho de atualização.

Trabalhos também poderiam ser desenvolvidos visando incrementar a ferramenta de navegação com relatórios e possibilidade de quantificaçāo respondendo, por exemplo, ao usuário quantos nós compõem uma determinada ligação. Isso se a base de dados apresentar várias ligações como esta deste trabalho.

Outro trabalho interessante seria o acompanhamento da implantação desse sistema junto ao usuário, identificando as facilidades e dificuldades encontradas em 
seu uso. Por exemplo, até que ponto é claro para o usuário que ele está caminhando por assuntos que constituem um processo ?, isto $\hat{\epsilon}$, de um trecho de texto de ata o usuário segue para outro trecho de texto, ele, certamente, precisará ler para saber em que ponto do processo está, tornando cansativo o processo de consulta.

E, ainda, um outro trabalho poderia ser a aplicação do método apresentado em outro contexto, observando o quanto o ele colabora e melhora o entendimento entre usuário e especialistas para a solução do problema. 


\section{Bibliografia}

[Bi88] Bigelow, J. Hypertext and CASE. IEEE Software pp. 23-27. March 1988.

[Co91] Cognetics Corporation. Hyperties - version 3.0 - user's guide. Princeton Junction. 1991.

[Co87] Conklin, J. Hypertext: an introduction and survey. Computer 2(9), pp. 1741. September 1987.

[Co88] Conklin, J. \& Begeman, M. L. gIBIS: a hypertext tool for exploratory policy discussion. ACM Transations on Office Information Systems 6(4), pp. 303-331. October 1988.

[De86] Delisle, N. \& Schwartz, M. Neptune: a hipertext system for CAD applications. Communications of the ACM, pp. 132-143. 1986. 
[De89] Delisle, N. \& Schwartz, M. Collaborative writing with hipertext. IEEE Transactions on Professional Communication 32(4), pp. 183-188. September 1989.

[E191] Ellis. C. A. et al. Groupware: some issues and experiences. Communications of the ACM 34(1), pp.38-58. January 1991.

[Fu89] Furuta, R. et al. A spectrum of automatic hypertext constructions. Hypermedia 1(2), pp. 179-195. 1989.

[G189] Glushko, R. J. Transforming text into hypertext for a compact disc encyclopedia. CHI'89 Proceedings, pp. 293-298. 1989.

[Ha90] Hall, P. A. V. \& Papadopoulos, S. Hypertext systems and applications. Information and Software Technology 32(7), pp.477-490. September 1990.

[Ha89] Hardman, L. Evaluating the usability of the Glasgow online hypertext. Hypermedia 1(1), pp. 34-63. 1989.

[Ha88] Harel, D. On visual formalisms. Communications of the ACM 31(5), pp. 514-530. May 1988.

[Ma88] Marchionini, G. \& Shneiderman, B. Finding facts vs. browsing knowledge in hypertext system. Computer 21(1), pp. 70-80. January 1988.

[Ni90] Nielsen, J. The art of navigation trough hypertext. Communications of the ACM 33(3), pp. 296-310. March 1990. 
[Sa85] Sarin, S. Computer-based real-time conferecing systems. Computer 18(10), pp. 33-45. October 1985.

[Sa92] Salgado, A. C. et al. Sistemas de hipermídia: hipertexto e banco de dados. VIII Escola de Computação. Porto Alegre. 194 p. 1992.

[Sh89] Shneiderman, B. et al. Evaluating three museum installations of a hypertext system. Journal of the American Society for Information Science 40(3), pp. 172-182. May 1989.

[Si83] Sirbu, M. et al. OAM: an office analysis methodology. Office Automation Group Memo OAM-016. 39 p. Massachusetts Institute of Technology. 1983.

[St87] Stefik, M. et al. Beyond the chalkboard: computer support for collaboration and problem solving in meetings. Communications of the ACM 30(1), pp. 32-47. January 1987.

[St90] Streitz, N. A. et al. Chapter 23 - elaborating arguments: writing, learning and reasoning in a hypertext based environment for authoring. NATO ASI Series F67, pp. 407-437. Jonassen, D. H. e Mandl, H. (ed) Springer-Verlag Berlin Heidelberg. 1990

[Ya88] Yankelovich, N. et al. Intermedia: the concept and the constructions of a seamless information enviroment. Computer, pp. 81-96. January 1988. 


\section{Apêndice}

Trecho reproduzido do Regimento Geral da USP. Título III - Das Unidades. Capítulo I - Da Congregação.

Art. 39 - À congregação compete:

I. - aprovar, por maioria absoluta, o regimento da Unidade e suas modificaçōes;

II - aprovar os regimentos de Departamentos;

III - propor ao Conselho Central de Graduação a estrutura curricular, dos cursos sob sua responsabilidade, bem como suas modificações;

IV - propor ao Conselho Central de Graduação os programas das disciplinas ministradas pela Unidade;

V - propor ao Conselho Central de Graduação a criação ou extinção de cursos de graduação;

VI - propor ao Conselho Universitário a criação, tramsformação ou extinção de Departamentos; 
VII - aprovar as propostas de abertura de concursos da carreira docente;

VIII - aprovar as inscriçōes dos candidatos aos concursos da carreira docente e à livre-docência;

IX - decidir sobre a composição das comissões julgadoras dos concursos da carreira docente e de livre-docência;

X - homologar o relatório da comissão julgadora de concursos da carreira docente e de livre-docência;

XI - aprovar, por dois terços da totalidade de seus membros, a suspensão de concursos da carreira docente e de livre-docência, por sua iniciativa ou por proposta do Conselho do Departamento;

XII - propor ao Conselho Universitário a criação de cargos docentes, mediante proposta do Conselho de Departamento, ouvido o Conselho Técnico-Administrativo (CTA);

XIII - deliberar sobre renovação contratual de docentes proposta pelos Departamentos;

XIV - aprovar, por proposta do Departamento, a contratação de professor colaborador, nos termos do art. 86 do Estatuto;

XV - aprovar, por proposta dos Departamentos, a admissão de professor visitante, nos termos do art. 87 do Estatuto e 194 deste regimento;

XVI - integrar a Assembléia Universitária para a eleição a que se refere o inciso II do art. 36 do Estatuto;

XVII - participar do colégio eleitoral da Unidade para a escolha da lista tríplice de Diretor e Vice-Diretor nos termos do art. 46 do Estatuto;

XVIII - eleger o seu representante e respectivo suplente no Conselho Universitário; 
XIX - eleger o representante e respectivo suplente da Unidade junto aos Conselhos Centrais, quando não houver qualquer das comissōes previstas no parágrafo único do art. 44 do Estatuto;

XX - opinar sobre a equivalência de títulos de pós-graduação, obtidos em outras instituiçōes de ensino superior do País ou do exterior;

XXI - deliberar sobre a revalidação de diplomas de graduação obtidos no exterior em instittuições de ensino superior;

XXII - deliberar sobre a aplicação de pena de desligamento de membros do corpo discente, assegurado a estes amplo direito de defesa;

XXIII - deliberar sobre a aplicação da pena de demissão de membros do corpo docente, assegurado a estes amplo direito de defesa, encaminhando o processo ao Reitor para execução;

XXIV - deliberar, em grau de recurso das decisōes do CTA, dos Conselhos dos Departamentos, das comissões referidas no art. 44 e parágrafo único do Estatuto;

XXV - deliberar sobre impugnação de atos do Diretor;

XXVI - delegar parte de suas atribuições ao CTA. 


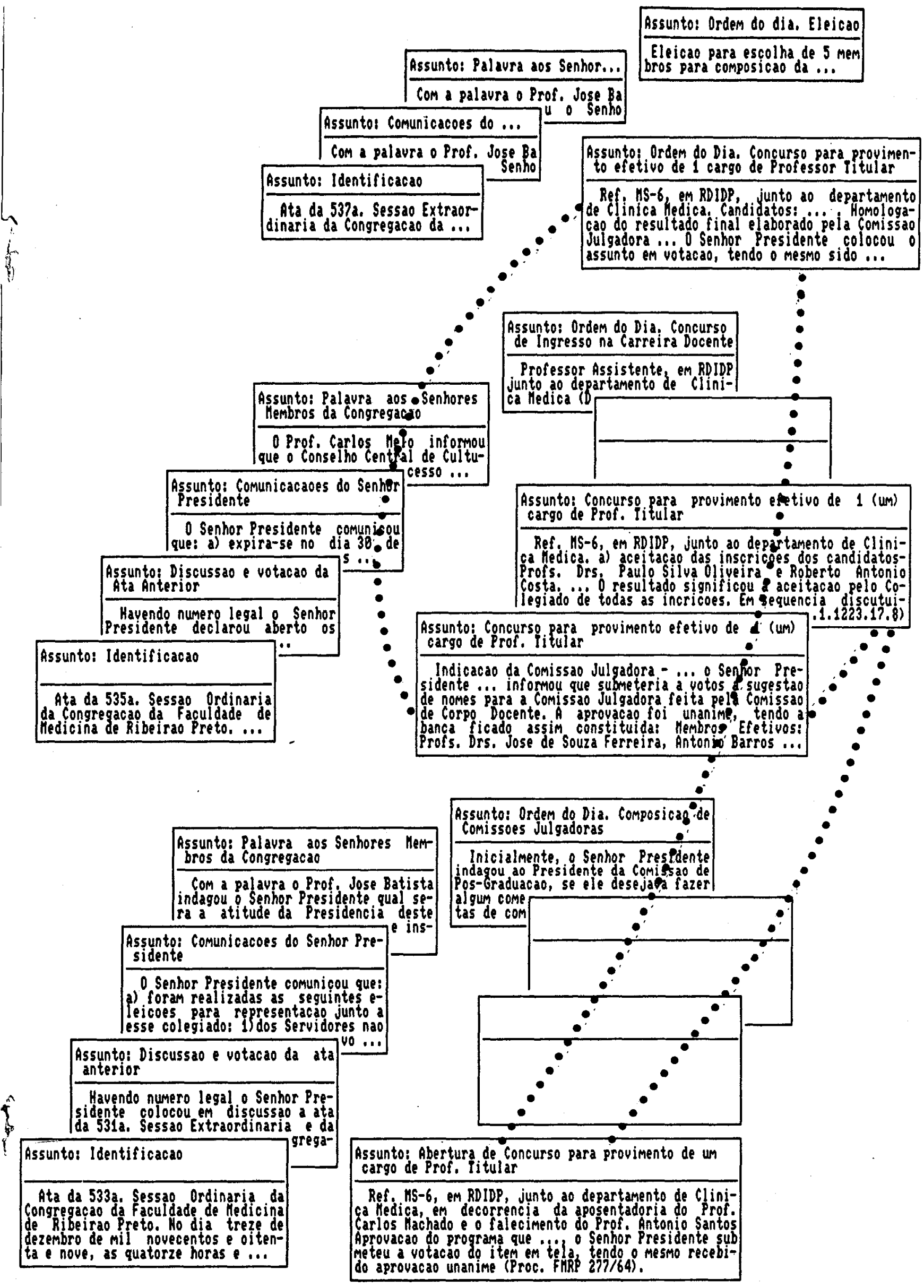

